\title{
EVAUALUATION OF THE EFFICACY OF THE STRESS PROTEIN RESPONSE AS A BIOCHEMICAL WATER QUALITY BIOMONITORING METHOD
}

\author{
DISSERTATION \\ Presented to the Graduate Council of the \\ University of North Texas in Partial \\ Fulfillment of the Requirements
}

For the Degree of

DOCTOR OF PHILOSOPHY

By

Scott D. Dyer, B.S., M.S.

Denton, Texas

May, 1991 
Dyer, Scott D., Evaluation of the Efficacy of the Stress Protein Response as

a Biochemical Water Quality Biomonitoring Method. Doctor of Philosophy

(Biology), May, 1991, 162 pp., 5 tables, 36 figures, references, 136 titles.

The stress protein response (SPR) is a conserved and ubiquitous

mechanism that enables cells to tolerate a wide variety of environmental insults. This response involves the preferential synthesis of an array of proteins with different molecular weights. These proteins perform a variety of functions, such as protein folding, multimeric protein assembly, steroid receptor binding, and heme catabolism.

To evaluate the potential use of the SPR as a biomonitoring tool, a stepwise plan was utilized that proceeded through various physical and chemical laboratory exposures and culminated with a field validation study. The goals of the laboratory exposures were threefold: 1) determine the time required for induction of the SPR; 2) determine the dose-responsiveness of the SPR; and 3) compare the increased syntheses and accumulations of stress proteins to classical toxicological endpoints (i.e. percent mortality, LC50, LC1, etc).

Brain, gill, and striated muscle tissues of fathead minnows (Pimephales promelas) exposed to heat shock, sodium arsenite, sodium chromate, lindane, and diazinon elicited tissue and stressor specific translation patterns. Increased syntheses and accumulations of several proteins were found to be concentration dependent at environmentally relevant levels. All tissues under all exposure 
regimes elicited a $70 \mathrm{kD}$ protein. This protein was determined to be indicative of general stress. Two proteins of 20 and $30 \mathrm{kD}$ were only found in fish exposed to arsenite and chromate. Thus, these two proteins may serve as metal indicators.

Gill of fathead minnows exposed in situ to a toxicity gradient in Soldier Creek, Midwest City, Oklahoma were found to accumulate stress protein 70 in a manner that reflected in stream fish species richness.

The results of this research demonstrates that the stress protein response has potential as a rapid and environmentally relevant biomonitoring method for assessing both general and stressor specific perturbations in fish. 


\section{ACKNOWLEDGMENTS}

I wish to express my gratitude and appreciation to the U.S. Air Force Office of Scientific Research for funding my doctoral research. I would also like to thank several individuals that provided guidance and assistance during my education at the University of North Texas. I thank Dr. Ken Dickson for serving as my major professor and mentor. His relaxed demeanor, optimism, and openness to new ideas helped create an environment that allowed my own talents to be expressed more fully. I also wish to thank him for granting me several opportunities to present results from my research at various state, national, and international scientific meetings. I also wish to thank Dr. Earl Zimmerman for serving as my minor professor, for taking such a keen interest in my project, and for his exceptional help in editing manuscripts intended for publication. I thank Dr. Brenda Sanders for providing a jumpstart into the field of stress proteins and for guiding my research and writing skills to a high standard. I also wish to thank Dr. Manus Donahue and Dr. Tom Waller for serving on my committee. To Lance Brooks, Joshua Barton, Marcy Clark, and Sean Covington, I thank you all for your excellent technical support, without it none of this would have been possible. Special thanks are extended to Teri Dyer for her speed typing, patience, perseverance, and lovingkindness throughout my graduate education. Immense appreciation is extended to the Lord God for allowing me the opportunity to discover more of His workmanship. 
TABLE OF CONTENTS

Page

LIST OF TABLES $\ldots \ldots \ldots \ldots \ldots \ldots \ldots \ldots \ldots \ldots \ldots \ldots$

LIST OF FIGURES $\ldots \ldots \ldots \ldots \ldots \ldots \ldots \ldots \ldots \ldots \ldots$ vi

Chapter

I. INTRODUCTION $\ldots \ldots \ldots \ldots \ldots \ldots \ldots \ldots \ldots \ldots$

III. HEAT SHOCK EXPERIMENTS $\ldots \ldots \ldots \ldots \ldots \ldots \ldots$

III. CHEMICAL EXPOSURES $\ldots \ldots \ldots \ldots \ldots \ldots \ldots \ldots \ldots \ldots$

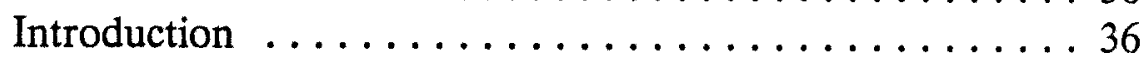

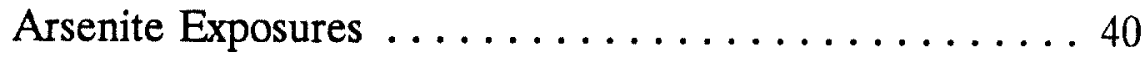

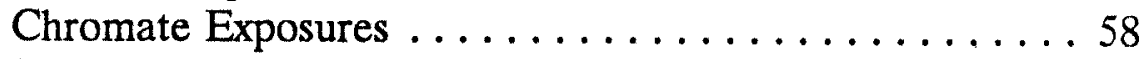

Lindane Exposures ................ 76

Diazinon Exposures . . . . . . . . . . . . 93

IV. PRELIMINARY FIELD VALIDATION . . . . . . . 117

V. GENERAL OVERVIEW AND CONCLUSIONS ........ 124

The Stress Protein Response Is Rapid . . . . . . . . 125

Sensitive and Environmentally Relevant . . . . . . . 127

Potential Indicators of General and

Stressor Specific Exposure . . . . . . . . . . . . . . . 128

Comparisons of Methodological Techniques . . . . . . 134

Potential Pitfalls ..................... 135

Future Needs and Scope . . . . . . . . . 137

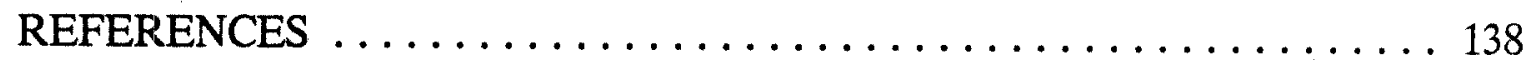




\section{LIST OF TABLES}

Table 1. Spearman rank correlations of stress protein intensities from striated muscle tissues versus $96-\mathrm{h}$ mortality $\ldots \ldots \ldots \ldots \ldots \ldots$

Table 2. A statistical summary of the diazinon induced proteins in brain of fish exposed to different concentrations of diazinon for $12 \mathrm{~h}$. Presented, are probabilities generated from Kruskal-Wallis analysis of variance and $\log$ (intensity) vs. diazinon concentration regression, plus resulting coefficients of determination. Mean \pm standard deviations of intensities determined from replicate fluorograms are also presented. *denotes significant

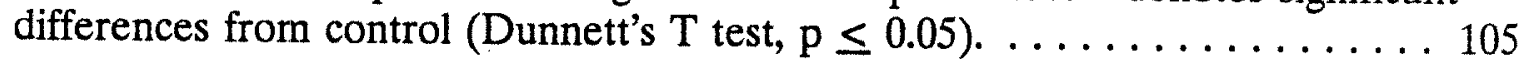

Table 3. A statistical summary of the diazinon induced proteins in striated muscle of fish exposed to different concentrations of diazinon for $12 \mathrm{~h}$. Presented, are probabilities generated from Kruskal-Wallis analysis of variance and $\log$ (intensity) vs. diazinon concentration regression, plus resulting coefficients of determination. Mean \pm standard deviations of intensities determined from replicate fluorograms are also presented. *denotes significant

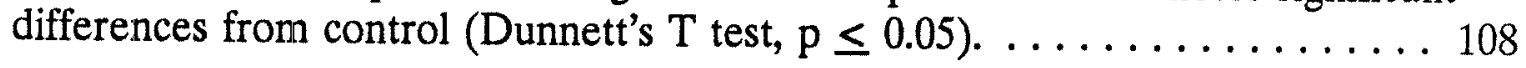

Table 4. Minimum detection levels for stress protein 70 , percent mortality of caged fish, in situ species, and numbers of individuals collected in Soldier Creek and North Canadian River, by site . . . . . . . . . . . . 121

Table 5. Comparison of the lowest observable effects concentrations (LOEC) for induction, as determined by radiolabel incorporation (R) or quantitative immunoblots $(\mathrm{Ab})$, of selected proteins, to calculated $\mathrm{LC} 50$ and $\mathrm{LC} 1$ values

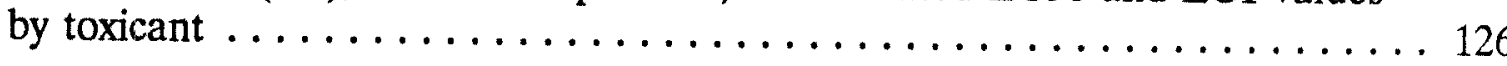




\section{LIST OF FIGURES}

Figure 1. Overlying fluorograms with respective densitometer tracings from tissues of fish exposed to $32^{\circ} \mathrm{C}$ for $1 \mathrm{~h}$. The intensity scale is in abitrary units. A. Gill- optically dense bands and underlying peaks corresponding to hsp's $63,68,70,78,90,100$ are indicated. B. Striated muscle- bands and peaks correspond to hsp's $70,78,90$, and 100. C. Brain- bands and peaks correspond to hsp's 70 and 90 .

Figure 2. A. A fluorogram of striated muscle protein from fathead minnows exposed to $34^{\circ} \mathrm{C}$ for 1 -hour and sampled at $0,0.5$, and 1 hours. Molecular weight markers of $97,66,42,31,21$, and $14 \mathrm{kD}$, respectively, are designated on the left. Arrows on the right denote heat shock proteins of 90 and $70 \mathrm{kD}$. B. Median intensities of 90 and $70 \mathrm{kD}$ proteins in fluorograms from replicate samples $(\mathrm{n}=3)$ of experiment described in A. Intensities were determined densitometrically and are presented as arbitrary units (see Materials and methods). Intensities which are statistically significantly greater than zero hour sample samples are designated by ${ }^{*} \ldots \ldots \ldots \ldots \ldots \ldots$

Figure 3. A. A fluorogram of striated muscle protein from fathead minnows exposed to $34^{\circ} \mathrm{C}$ for 1 -hour and then transferred to $25^{\circ} \mathrm{C}$ for 11 hours and sampled at $0,1,3,7$, and 11 hours post heat shock exposure. Molecular weight markers of $97,66,42,31,21$, and $14 \mathrm{kD}$, respectively, are designated on the left. Arrows on the right denote heat shock proteins of 90,78 and $70 \mathrm{kD}$. B. Median intensities of 90 , 78 , and $70 \mathrm{kD}$ proteins in fluorograms from replicate samples $(\mathrm{n}=3)$ of experiment described in A. Intensities were determined densitometrically and are presented as arbitrary units (see Materials and methods). Intensities which are statistically significantly greater than zero hour sample samples are designated by ${ }^{*} \ldots \ldots \ldots \ldots \ldots 21$ 
Figure 4. A. A fluorogram of gill tissue proteins from fathead minnows transferred to water at 28 to $34^{\circ} \mathrm{C}$ for $1 \mathrm{~h}$ and control minnows maintained at $25^{\circ} \mathrm{C}$. Molecular weight markers of $97,66,42,31,21$, and $14 \mathrm{kD}$, respectively, are designated on the left. Arrows on the right denote heat shock proteins of $100,90,78,70,68$ and $60 \mathrm{kD}$ respectively. B. Median intensities of $100-, 90-, 78-, 70-, 68-$ and $60-\mathrm{kD}$ proteins in fluorograms from replicate samples $(n=5)$ of experiment described in A. Intensities were determined densitometrically and are presented as arbitrary units (see Materials and Methods). Intensities which are statistically significantly higher than controls are indicated by ${ }^{*} \ldots \ldots \ldots 23$

Figure 5. A. A fluorogram of striated muscle proteins from fathead minnows transferred to water at 28 to $34^{\circ} \mathrm{C}$ for $1 \mathrm{~h}$ and control minnows maintained at $25^{\circ} \mathrm{C}$. Molecular weight markers of $97,66,42,31,21$, and $14 \mathrm{kD}$, respectively, are designated on the left. Arrows on the right denote heat shock proteins of $100,90,78$ and $70 \mathrm{kD}$ respectively. B. Median intensities of 100-, 90-, 78-, and 70-kD proteins in fluorograms from replicate samples $(n=5)$ of experiment described in A. Intensities were determined densitometrically and are presented as arbitrary units (see Materials and Methods). Intensities which are statistically significantly higher than controls are indicated by ${ }^{*} \ldots \ldots \ldots 24$

Figure 6. A. A fluorogram of brain tissue proteins from fathead minnows transferred to water at 28 to $34^{\circ} \mathrm{C}$ for $1 \mathrm{hr}$ and control minnows maintained at $25^{\circ} \mathrm{C}$. Molecular weight markers of $97,66,42$, 31,21 , and $14 \mathrm{kD}$, respectively, are designated on the left. Arrows on the right denote heat shock proteins of 90,70 , and $67 \mathrm{kD}$, respectively. B. Mean intensities of $90-, 70-$, and $68-\mathrm{kD}$ proteins in fluorograms from replicate samples $(n=2)$ of experiment described in A. Intensities were determined densitometrically and are presented as arbitrary units (see Materials and Methods) Intensities which are statistically significantly higher than controls are indicated by ${ }^{*} . \ldots \ldots \ldots \ldots \ldots 25$

Figure 7A. A fluorogram of striated muscle proteins from tissue exposed in vitro to temperatures of $25,28,31,34,37,40$, and $43^{\circ} \mathrm{C}$ for 1 hour. Molecular weight markers of $97,66,42,31,21$, and $14 \mathrm{kD}$, respectively, are designated on the left. Arrows on the right denote heat shock proteins of 100,90 , and $70 \mathrm{kD}$, respectively. B. Median intensities of 100,90 , and $70 \mathrm{kD}$ proteins in fluorograms from replicate samples $(n=3)$ of experiment described in 7A. Intensities were determined densitometrically and are presented as arbitrary units (see Materials and methods). Intensities which are statistically significantly greater than controls, as determined by

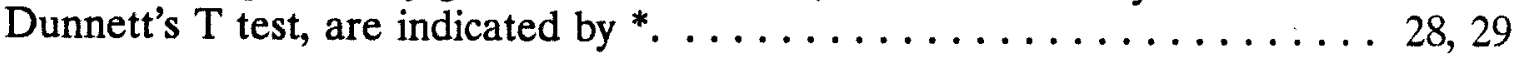


Figure 8. A fluorgram of gill tissue proteins from fish exposed to $25 \mathrm{mg} \mathrm{As} / \mathrm{L}$ for $0,2,4,6,8$, and $10 \mathrm{~h}$. Molecular weight markers are designated on the left. Arrows on the right denote stress proteins of

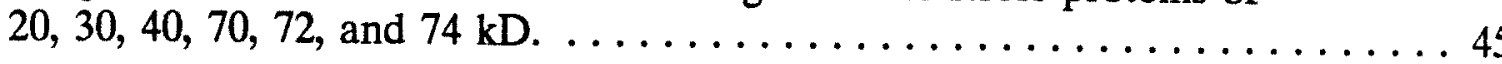

Figure 9. A. A fluorgram of gill tissue proteins from fish exposed to $0,6.0,9.6,17.7,26.7$, and $35.6 \mathrm{mg} \mathrm{As} / \mathrm{L}$ for $8 \mathrm{~h}$. Molecular weight markers are designated on the left. Arrows on the right denote stress proteins of $20,30,40,70,72$, and $74 \mathrm{kD}$. B. Median intensities of 20-, 30-, 40-, 70-, 72-, 74-kD proteins in fluorograms from replicate samples $(n=5)$ of experiment described in A.

Figure 10. A. A fluorgram of striated muscle tissue proteins from fish exposed to $0,6.0,9.6,17.7,26.7$, and $35.6 \mathrm{mg} \mathrm{As} / \mathrm{L}$ for $8 \mathrm{~h}$. Molecular weight markers are designated on the left. Arrows on the right denote stress proteins of $20,30,68,70$, and $90 \mathrm{kD}$. B. Median intensities of $20-, 30-, 68-, 70-$, and $90-\mathrm{kD}$ proteins in fluorograms from replicate samples $(n=5)$ of experiment described in $10 \mathrm{~A} \ldots \ldots \ldots \ldots \ldots \ldots \ldots \ldots, 49$

Figure 11. A. Western blot of striated muscle tissue proteins, from fish that survived the $96 \mathrm{~h}$ toxicity test, against a monoclonal antibody raised against hsp70 (from Dr. W. Welch; Riabowol et al., 1988). Samples of equal protein were separated on a $12.5 \%$ polyacrylamide gel before blotting. Prestained molecular weight markers of 75 and $50 \mathrm{kD}$ are designated on the left. The arrow on the right denotes a single band with an apparent molecular weight of $70 \mathrm{kD}$. B. Western blot of striated muscle tissue proteins, from fish surviving the $96 \mathrm{~h}$ toxicity test, against a monoclonal antibody raised against hsp60 (from Dr. S. Miller; Miller, 1987). Samples were run as described in A. Prestained molecular weight markers 75 and 50 $\mathrm{kD}$ are designated on the left. The arrow on the right denotes a single band with an apparent molecular weight of $60 \mathrm{kD} . \ldots \ldots \ldots \ldots \ldots \ldots \ldots$

Figure 12. A fluorgram of gill tissue proteins from fish exposed to 100 $\mathrm{mg} \mathrm{Cr} / \mathrm{L}$. (nominal) for $0,2,4,6,8,10$, and $12 \mathrm{~h}$. Molecular weight markers are designated on the left. Arrows on the right denote stress proteins of 20,30 , and $70 \mathrm{kD} \ldots \ldots \ldots \ldots \ldots \ldots \ldots \ldots \ldots \ldots \ldots \ldots \ldots \ldots \ldots \ldots \ldots$ 
Figure 13. A. A fluorgram of gill tissue proteins from fish exposed to $0,9.9,49.7,75.4,104.9$, and $159.4 \mathrm{mg} \mathrm{Cr} / \mathrm{L}$ for $12 \mathrm{~h}$. Molecular weight markers are designated on the left. Arrows on the right denote stress proteins of 20,30 , and $70 \mathrm{kD}$. B. Median intensities of $20-, 30-, 70-\mathrm{kD}$ proteins in fluorograms from replicate samples $(n=5)$ of experiment described in 13A. ....................... 65, 66

Figure 14. A. A fluorgram of striated muscle tissue proteins from fish exposed to $0,9.9,49.7,75.4,104.9$, and $159.4 \mathrm{mg} \mathrm{Cr} / \mathrm{L}$ for $12 \mathrm{~h}$.

Molecular weight markers are designated on the left. Arrows on the right denote stress proteins of 20,30 , and $70 \mathrm{kD}$. B. Median intensities of $20-, 30-, 70-\mathrm{kD}$ proteins in fluorograms from replicate samples $(\mathrm{n}=5)$ of experiment described in A. ..................... 68

Figure 15. Quantitative immunoblots of gill and striated muscle tissue of fish exposed to $0,9.9,49.7,75,4$, and $104.9 \mathrm{mg} \mathrm{Cr} / \mathrm{L}$ for $96 \mathrm{~h}$ using an antibody raised against hsp70. Blots with gill protein are designated on the left, while blots with striated muscle are on the right.

Figure 16. The relationships between accumulation of the $68-\mathrm{kD}$ protein, as determined via quantitative immunoblots, and percent mortality of fish exposed to different chromium concentrations for $96 \mathrm{~h}$. Open bars correspond to mean number of micrograms of total protein required for minimum stress protein detection \pm standard deviation. Hatched bars correspond to mean percent mortality \pm SD. Asterix denote significance from controls, as determined by Dunnett's $\mathrm{T}$ tests. ............ 70

Figure 17. A fluorogram of brain tissue proteins from fish exposed to 220.0 ug lindane/L for $0,2,4,6,8,10$, and $12 \mathrm{~h}$. Molecular weight markers are designated on the left. Arrows on the right denote proteins

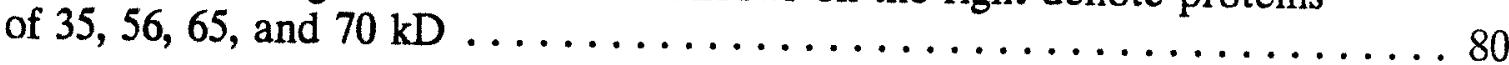

Figure 18. A fluorogram of striated muscle tissue proteins from fish exposed to 220.0 ug lindane $/ \mathrm{L}$ for $0,2,4,6,8,10$, and $12 \mathrm{~h}$. Molecular weight markers are designated on the left. Arrows on the right denote proteins of 56,70 , and $90 \mathrm{kD}$ 80

Figure 19. A fluorogram of gill tissue proteins from fish exposed to 220.0 ug lindane $/ \mathrm{L}$ for $0,2,4,6,8,10$, and $12 \mathrm{~h}$. Molecular weight markers are designated on the left. Arrows on the right denote proteins

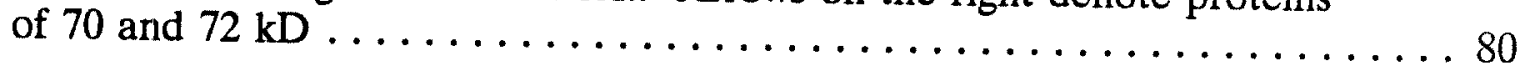


Figure 20. A. A fluorgram of gill tissue protein from fish exposed to $0,7.5,18.7,47.5$, and 84.3 ug lindane $/ \mathrm{L}$ for $12 \mathrm{~h}$. Molecular weight markers are designated on the left. Arrows on the right denote stress proteins of 70 and $72 \mathrm{kD}$. B. Median intensities of $70-$ and $72-\mathrm{kD}$ proteins in fluorograms from replicate samples $(n=4)$ of experiment described in A. . 84

Figure 21. A. A fluorgram of brain tissue protein from fish exposed to $0,7.5,18.7,47.5$, and 84.3 ug lindane/L for $12 \mathrm{~h}$. Molecular weight markers are designated on the left. The arrow on the right denotes a stress protein of $70 \mathrm{kD}$. B. Median intensities of the $70-\mathrm{kD}$ protein in fluorograms from replicate samples $(n=4)$ of experiment described in A. . . . . . 85

Figure 22. A. A fluorgram of striated muscle tissue protein from fish exposed to $0,7.5,18.7,47.5$, and 84.3 ug lindane $/ \mathrm{L}$ for $12 \mathrm{~h}$. Molecular weight markers are designated on the left. The arrow on the right denotes a stress protein of $70 \mathrm{kD}$. B. Median intensities of the $70-\mathrm{kD}$ protein in fluorograms from replicate samples $(n=4)$ of experiment described in A. 86,87

Figure 23. Histograms that illustrate the relationships of the $70-\mathrm{kD}$ gill protein, as determine by quantitative immunoblots, and percent mortality of fish exposed to different lindane concentrations for $96 \mathrm{~h}$. Open bars correspond to mean number of micrograms to total protein required for minimum stress protein detection \pm standard deviation. Hatched bars correspond to mean percent mortality \pm SD. Asterix denote significance from controls, as determined by Dunnett's $\mathrm{T}$ tests $\ldots \ldots \ldots . \ldots 8$

Figure 25. A fluorogram of gill tissue proteins from fish exposed to $8 \mathrm{mg}$ diazinon/L (nominal) for $0,4,8,12$, and 24h. Molecular weight markers are designated on the left. Arrows on the right denote proteins

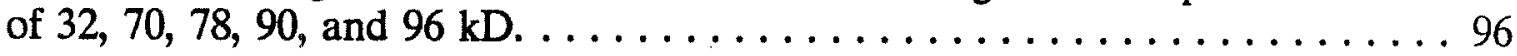

Figure 26. A fluorogram of brain and striated muscle tissue proteins from fish exposed to $8 \mathrm{mg}$ diazinon/L (nominal) for $0,4,8,12$, and $24 \mathrm{~h}$. Molecular weight markers are designated on the left. Arrow on the right

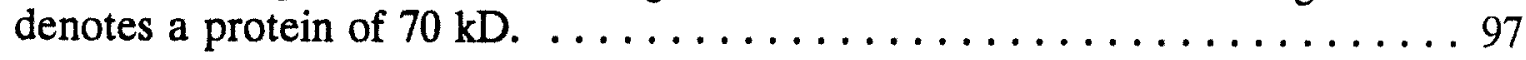

Figure 27. A fluorgram of gill tissue protein of fathead minnows exposed to $0,1.4,2.4,3.4,3.8$ and $5.6 \mathrm{mg}$ diazinon $/ \mathrm{L}$ for $12 \mathrm{~h}$. Molecular weight markers are designated on the left. The arrows on the right denote proteins of $32,70,78,90$, and $96 \mathrm{kD} . \ldots \ldots \ldots \ldots \ldots 10 \ldots \ldots$ 
Figure 28. A fluorgram of brain tissue protein of fish exposed to $0,1.4,2.4,3.4,3.8$ and $5.6 \mathrm{mg}$ diazinon/L for $12 \mathrm{~h}$. Molecular weight markers are designated on the left. The arrows on the right denote proteins of $32,33,35,36,40,42,52,55,60,70,90,96$, and $105 \mathrm{kD} . \ldots \ldots 102$

Figure 29. A fluorogram of brain tissue of fish exposed to a range of diazinon concentrations. Lanes were normalized to radioactivity $(150,000 \mathrm{cpm})$. Molecular weight markers are designated on the left. The arrows on the right denote proteins of $32,33,42,52,55,60,70$ 90,96 , and $105 \mathrm{kD}$.

Figure 19. A fluorgram of striated muscle tissue protein from fish exposed to $0,1.4,2.4,3.4,3.8$ and $5.6 \mathrm{mg}$ diazinon/L for $12 \mathrm{~h}$. Molecular weight markers are designated on the left. The arrows on the right denote stress proteins of $24,26,27,32,33,35,42,52,55,60,70,78,90,96,105$, 108 , and $110 \mathrm{kD}$.

Figure 31. A fluorogram of striated muscle tissue protein of fish exposed to a range of diazinon concentrations. Lanes were normalized to radioactivity $(150,000 \mathrm{cpm})$. Molecular weight markers are designated on the left. The arrows on the right denote proteins of $32,42,52,55,60,70,90,96$, 105,108 , and $110 \mathrm{kD}$. .

Figure 32. Locations of fish cages and in situ fish collection sites on Soldier Creek and North Canadian River during 7/90 and 9/90.

Figure 33. Line diagram that illustrates the relationships between accumulation of stress protein 70 in gill tissue of caged fish and in situ fish species richness to site location.

Figure 34. Translation patterns observed in gill tissue of fathead minnows exposed to five different stressors: heat shock, arsenite, chromate, lindane, and diazinon. . . . . . . . . . . . . . . 128

Figure 35. Translation patterns observed in striated musclel tissue of fathead minnows exposed to five different stressors: heat shock, arsenite, chromate, lindane, and diazinon. 
Figure 36. Translation patterns observed in brain tissue of fathead minnows exposed to five different stressors: heat shock, arsenite, chromate, lindane, and diazinon. . . . . . . . . . . . . . . 130 


\section{CHAPTER I}

\section{INTRODUCTION}

Chemical and physical demands of life in water impose rigorous constraints on aquatic species. Superimposed on such demands may be the additional physiological constraints from anthropogenic contaminants. Stresses of anthropogenic origin are multiple in nature, and aquatic life may be subjected to some or all of the following: exposures to acute and sublethal levels of contaminants; unfavorable fluctuating temperatures, adverse light levels; increased sediment loads, etc. (Wedemeyer et al., 1984). Each of these factors, singly or together, can impose a considerable load, or stress, on physiologic systems.

Stress can be defined as a measurable alteration of a physiological homeostatic condition which is induced by an environmental variable which may render the organism more vulnerable to further environmental perturbations. It is a stimulus-response phenomenon, hence a stress-response. Stress responses are extreme forms of "normal" adaptive responses to environmental stimuli (Pickering, 1981). A continuance of stress, such as sublethal stresses, may result in adverse effects at the individual organism level that are eventually manifested in succeedingly higher levels of biological organization, such as population and community levels (Wedemeyer et al., 1984). 
Environmental stress responses begin at the molecular/cellular level and then extends to tissues and organs, whose responses occur before changes in populations and ecosystems (Bouk, 1984). In the past, environmental monitoring techniques involving whole-animal and population responses, such as mortality, gross abnormalities (Sonstegard and Leatherland, 1984), hormesis (Stebbing, 1981), altered condition indices, growth (Passino, 1984), behavioral changes, and population changes (Winner et al., 1980) have been used as general stress indicators. Although these responses to date have been the best criteria for evaluating general stress, they have several limitations: 1) they are not based on the mechanisms which underlie the relationship between general stress physiology and toxicity; 2) they measure stress indirectly; and 3) they function at the organismal level and lack the sensitivity of biochemical/cellular parameters (Jenkins and Sanders, 1986). Therefore, if biochemical/cellular parameters could be significantly correlated to higher order effects (i.e. organ, organism, population, etc.) then these parameters could provide an early warning of excessive environmental perturbations and would do so comparatively faster and cheaper than monitoring whole animal and population responses.

Early detection of changes in the quality of water resources, especially those impacted by anthropogenic contaminants, is of primary concern to individuals involved with managing these resources. The associated fisheries, both commercial and recreational, represent a valuable resource which can be irreparably impacted, as well. Those charged with managing water resources rely 
heavily on chemical, physical and biomonitoring techniques. A need exists for a rapid means of assessing the "health" of rivers, reservoirs, and estuaries in the nation. A reliable, biomonitoring method which determines stress levels in fish could provide resource managers with a valuable tool to determine if chemicals from point and non point source pollution are adversely impacting aquatic systems.

Over the past decade, investigations into the use of biochemical parameters (biomarkers) as indicators of pollutant exposure and effects have intensified. Unfortunately, their clinical use is lacking (Bouk, 1984). Clinical use implies that the method has been validated by extensive testing- both to identify the biological significance of the parameter and the limitations in applying the test to the species in question.

Much of the early biomarker work involved measurements of blood and enzyme activity as well as biochemical composition of blood and tissues (Mazeud and Mazeud, 1981; Neff, 1985), methods primarily transplanted from human and veterinary medicine. Unfortunately, many of these parameters were not applicable across phyla and measured secondary effects, symptoms, of an underlying problem rather than highly conserved parameters intimately involved in the protection and/or defense of the cell. Thus, biomarkers that correspond to events that are coupled to cellular protection and defense systems could serve as highly sensitive indicators of contaminant exposure and adverse biological effects (Sanders et al., in press). 
Recently, a cellular protective response has been identified which is involved in protecting organisms from such detrimental effects of exposure to a variety of physical and chemical stressors. This response, referred to as the heat shock or stress response, involves the preferential synthesis of a suite of proteins referred to as heat shock proteins (hsp's), as a result of exposures to elevated temperatures (Lindquist 1986). However, this response has also been shown to be induced by a wide variety of chemical and biologic stressors such as, dinitrophenol, metals, oxidizing agents, steroids, sulfhydryl-reactive agents, and viral infection, hence, are also called stress proteins (Nover, 1984; Schlesinger, 1990). The number of stress proteins induced and their exact size appear to be tissue, species, and stressor specific. However, four major groups of stress proteins have been found in eukaryotes: sp90, sp70, sp60, and sp's 30-20 (the numbers refer to their molecular weight in kilodaltons, $\mathrm{kD}$ ).

The $90-\mathrm{kD}$ stress protein group has been shown to be associated with steroid receptors (Baulieu, 1989), the aryl hydrocarbon hydroxylase receptor (Perdew, 1988), and a translational initiation factor kinase (Rose et al., 1989). Thus, sp90 is intimately involved in the transcription and translation machinery of the cell.

At least three functions of $\mathrm{sp} 70$ have been defined in normal cellular metabolism, and they are: multimeric protein assembly, unfolding for translocation, and disaggregation of protein aggregates (Craig, 1989; Rothman, 1989; Welch, 1990). In a stress situation, these functions are thought to facilitate 
repair of proteins and protein complexes associated with common and critical physiological processes, and thus protect cells from stressor-induced damage. Multimeric protein assembly in the mitochondria has been found to be accomplished by sp60 (Cheng et al., 1989; Ostermann et al., 1989). Little is known about the functions of the remaining group of stress proteins, 30-20. However, several investigations have shown that some of these proteins are phosphorylated during cell stress and subsequently accumulate in the nucleus and other large sedimenting organelles, where it is suggested that they perform their processes (Kim et al., 1984; Duband et al., 1986; Arrigo, 1987; Duncan and Hershey, 1987; Regazzi et al., 1988).

This dissertation describes the results of a research project that was designed to evaluate the potential use of the stress protein response (SPR) as a water quality biomonitoring method. The research was built upon a stepwise plan that involved both laboratory and field experiments.

Laboratory experiments were comprised of two types: heat shock exposures and chemical exposures. The heat shock study involved the in vivo and in vitro exposure of fathead minnows (Pimephales promelas) and tissues to elevated temperatures. There were two objectives to this set of experiments: 1) to develop a classical stress protein response data base, or foundation, from which results could be compared to the vast heat shock literature; and 2) serve as a launching pad to which chemical exposure results could be referenced.

To evaluate the expression of the stress proteins as biomarkers of effects 
and/or chemical exposure, an experimental regime was designed in which fathead minnows were exposed to chemicals with different modes of action for various lengths of time and to a wide range of concentrations. The objectives of this research endeavor were fourfold: 1) to determine the time required for the SPR to be induced and time(s) in which maximum stress protein synthetic rates occurred; 2) to determine the effect of chemical concentration on stress protein synthesis and accumulation; 3) to determine tissue specificity of the SPR; and 4) to correlate the synthesis and accumulation of induced stress proteins to a known effect, namely percent mortality.

Several studies with cell lines have shown that the expression of different arrays of stress proteins is chemical specific (Courgeon et al., 1984; Honda et al., 1986; Shelton et al., 1986). Therefore, the potential chemical specificity of the SPR was examined by exposing fish to toxicants in which mode of action and/or effects were well documented.

Sodium arsenite is the best known chemical inducer of the SPR (Duncan and Hershey, 1987; Kapoor and Lewis, 1987; Hiwasa and Sakiyama, 1986). It binds to thiol groups on proteins thereby inhibiting oxidative pathways, non-lysosomal degradation of proteins, and impairing tissue respiration (Webb, 1966; Goyer, 1986; Munro and Pelham, 1986; Klemperer and Pickart, 1989). 
Sodium chromate (CrVI) has been shown to oxidize proteins and DNA (Ono, 1988; Nieboer and Jusys, 1988; Nieboer and Shaw, 1988). When reduced to CrIII, it has high affinity for nucleotides and nucleic acids and can alter their threedimensional geometry. Thus, it is a potent mutagen and carcinogen (Ono, 1988; Nieboer and Shaw, 1988; Yassi and Nieboer, 1988). In addition, chromate has been shown to cause structural damage to fish gill and concentrate in the nuclear fraction (Van der Putte, et al., 1981; Van der Putte and Part, 1982).

Lindane is an organochlorine insecticide that has a mode of action similar to toxaphene and cyclodiene insecticides. Toxicity of lindane is a result of its inhibition of the GABA-activated chloride channel in the nerve (Matsumura and Ghiasuddin, 1983; Woolley and Zimmer, 1986; Fishman and Gianutsos, 1987; Joy et al., 1987; Ogata et al., 1988). Thus, it inhibits GABA's ability to suppress excitation in nerves. In aquatic organisms, lindane has been shown to disrupt osmoregulatory mechanisms, alter the membrane lipidic matrix, and inhibit protein synthesis (Demael et al., 1987; Shirley and McKenney, 1987; Al-Chalabi and AlKhayat, 1989).

Diazinon is an organophosphate insecticide that inhibits cholinesterase activity (Matsumura,1985; Murphy, 1986; Durham, 1987). In fish, this toxicant has been shown to inhibit oxygen consumption and oxidative enzymes (Rao and Rao, 1979; Vijayalakshmi, 1980; Basha et al., 1984). 
Based on results from all of the laboratory experiments, verification of the efficacy of the SPR as a sentinel of environmental perturbations was evaluated further via in situ (field) exposures of laboratory-raised fish. A preliminary field trial was performed on a creek known to possess an acute to chronic toxicity gradient. The field study was performed in Soldier Creek, Midwest City, Oklahoma. Previous studies have shown that the creek has been impacted by industrial effluent from Tinker Air Force Base. Acute toxicity and an impoverished fish community have been reported (ONTECH Inc. and TRAC Laboratory, Inc., 1987; Simpson et al., 1987).

There were three objectives to the field study: 1 ) identify a toxicity gradient via acute in situ fathead minnow toxicity tests; 2) determine the fish species composition along the length of the creek; and 3) relate the SPR from caged minnows to survival and faunal fish species richness. Field verification is a critical step because exposure to complex patterns of natural and anthropogenic environmental variables may result in different SPR's as compared to laboratory exposures.

Briefly, data accumulated to date from both laboratory and field experiments have shown that the stress protein response is: 1) rapid, occurring within hours of stressor exposure; 2) sensitive, even at sublethal exposures; 3) significantly correlated to concentration and survival; and 4) potentially indicative of chemical class, or mode of action. While not a part of the original research plan, the usefulness of an immunological technique that measures accumulation of 
stress proteins suggests that this method is very sensitive and serves well as an indicator of general stress. 


\title{
CHAPTER II
}

\section{HEAT SHOCK EXPERIMENTS}

\author{
Introduction
}

Behavioral and physiological responses which enable organisms to tolerate a wide range of temperatures encountered in their environment have been well characterized (see reviews in Bowler and Fuller, 1987). With respect to temperature tolerance, it has been widely acknowledged that the higher the level of biological organization, the more thermal sensitive are the processes involved. For example, the maximum temperature at which the whole organism can survive is usually lower than the maximum temperature at which many of its constituent tissues and cells can function (Ushakov, 1964; Roberts, 1973; Lagerspetz, 1987).

Explanations of the causative factors responsible for lethality due to acute temperature exposure have involved a search for the "weakest link" or rate limiting physiological process (Roberts, 1973; Lagerspetz, 1987). Studies have shown that a primary source of cellular damage from acute heat exposure involves the malfunction of receptor proteins and other processes associated with intercellular communication (White, 1976, 1983; Calderwood, 1987). Nervous tissue is particularly sensitive to elevated temperatures, and it has been suggested that the release of neurotransmitters from the presynaptic neuron may be extremely thermal sensitive and a limiting step leading to thermal death 
(Roberts, 1973; Crawshaw, 1979; White, 1983; Lagerspetz, 1987). In fish under extreme thermal stress, regions of the brain appear to be the most sensitive, and lethality may result from failure of the central nervous system to control respiration causing a critical drop in brain $\mathrm{pO}_{2}$ (Tsukuda, 1961; Roberts, 1973).

Recently a cellular protective response has been identified which might be involved in protecting organisms from such detrimental effects of exposure to elevated temperatures. This response, referred to as the heat shock or stress response, involves the preferential synthesis of a suite of proteins referred to as heat shock proteins (hsp's) in reaction to exposure to elevated temperatures and other environmental stressors (Atkinson and Walden, 1985; Lindquist, 1986). Heat shock proteins are ubiquitous and highly conserved. Synthesis of hsp's is closely correlated with the phenomenon of heat hardening or thermotolerance in which a conditioning heat shock confers the ability to survive a subsequent, more severe heat shock that otherwise would be lethal to the organism (Landry et al., 1982; Gedamu et al., 1983; Mosser et al., 1987; Bosch et al., 1988).

It is now becoming clear that at least two of these hsp's, hsp60 and hsp70, have important functions in cells under normal conditions and take on dual, protective and repair, roles upon exposure to elevated temperatures (Rothman, 1989; Welch, 1990). For example, members of the large hsp70 family are believed to be catalysts of protein folding (Rothman, 1989; Beckman et al., 1990). Under normal conditions hsp70 chaperones proteins in an unfolded configuration from their site of synthesis in the cytoplasm to the appropriate intracellular 
compartment for transport across the membrane (Chirco et al., 1988; Deshaies et al., 1988; Craig, 1989). Another member of the hsp70 family, which resides in that compartment, then facilitates the appropriate folding of the newly imported protein (Craig, 1989). In addition, hsp60, occurring exclusively in mitochondria, is involved in the folding and assembly of the numerous large enzyme-protein complexes associated with this organelle's inner membrane (Cheng et al., 1989; Ostermann et al., 1989).

Upon exposure to adverse environmental conditions, such as elevated temperatures, it has been suggested that hsp60 and hsp70 can also perform the related functions of renaturing damaged peptides and resolubilizing protein aggregates (Rothman, 1990; Welch, 1990). Therefore, hsp's might facilitate the repair of proteins and protein complexes associated with critical physiological processes and, thereby, protect cells from heat induced damage. Because of their role in protection from the detrimental effects of elevated temperatures, it was hypothesized that if malfunctioning of the nervous system is indeed rate limiting in organismal survival at high temperatures, it may be because this tissue has a limited capacity to synthesize and accumulate hsp's and is more vulnerable to heat induced damage.

To address this question, a set of experiments with the fathead minnow (Pimephales promelas) were designed. Initially, $25^{\circ}-\mathrm{C}$ acclimated fish were exposed to a wide range of temperatures to determine the maximum temperature at which they could survive for a $24-\mathrm{h}$ period. Using the maximum sublethal 
temperature, the time required for induction of the heat shock response in striated muscle via in vivo exposure was determined. In addition, the rate of recovery in muscle from in vivo hyperthermic exposures was also determined. The syntheses of hsp's in three tissues, striated muscle, gill, and brain were examined via 1-h exposures of the whole organism to a range of temperatures up to the maximum sublethal temperature. Lastly, the temperature range in which an individual tissue (striated muscle) can synthesize hsps was also determined, via in vitro exposures.

Results show that: 1) the heat shock response is rapid, occurring within $0.5 \mathrm{~h} ; 2$ ) hsp syntheses decreases to control rates by $7 \mathrm{~h} ; 3$ ) of the three tissues examined, brain synthesized the fewest heat shock proteins and had the least capacity to synthesize $\mathrm{sp} 70$ at $34^{\circ} \mathrm{C}$; and 4) the temperature range of the heat shock response in muscle exceeds that of the whole organism. These data support previous observations that thermotolerance of constituent tissues exceeds that of the organism and that neural tissue might be a rate limiting tissue in organismal survival. Further, the extreme sensitivity of brain tissue to elevated temperatures may be the result of the limited capacity of brain tissue to synthesize hsp's. 
Materials and Methods

Ninety- to 120-day-old fathead minnows (Pimephales promelas) were obtained from the University of North Texas, acclimated at $25^{\circ} \mathrm{C}$ with a $16 \mathrm{~L}: 8 \mathrm{D}$ photoperiod for at least 7 days, and fed frozen brine shrimp once daily to satiation. In initial experiments, fathead minnows were exposed to a broad range of temperatures to determine the maximum temperature at which they could survive. Fish (5 or 6) acclimated at $25^{\circ} \mathrm{C}$ were transferred to water at $33,34,35$, 36 , or $37^{\circ} \mathrm{C}$ for $24 \mathrm{~h}$ (three replicates per treatment). Control minnows were maintained at $25^{\circ} \mathrm{C}$.

In order to determine the length of time required for hsp induction, three replicates of three fish each were heat shocked at $34^{\circ} \mathrm{C}$ and sampled at $0,0.5$, and 1.0 hours. Immediately after sampling $(\mathrm{N}=9)$, fish were sacrificed and striated muscle (mean wet weight \pm standard deviation $=48.7 \pm 4.5 \mathrm{mg}$ ) was excised and pooled within each treatment replicate. Tissues were metabolically labeled for $2 \mathrm{~h}$ at $25^{\circ} \mathrm{C}$ with ${ }^{35} \mathrm{~S}$-methionine/cysteine. Incorporation of label into proteins was examined by SDS-PAGE and fluorography.

Another experiment was carried out to determine the length of time that the heat shock protein response was expressed after removal from heat stress. Fish were exposed to $34^{\circ} \mathrm{C}$ water for $1 \mathrm{~h}$, transferred back to the control temperature $\left(25^{\circ} \mathrm{C}\right)$ and sampled at $0,1,3,7$, and 11 hours after heat shock. Three replicates of three fish each were used for each treatment. Immediately after sampling $(\mathrm{N}=15)$ fish were sacrificed, and striated muscle was pooled (48.2 
$\pm 3.6 \mathrm{mg}$ ) and incubated with ${ }^{35} \mathrm{~S}$-methionin/cysteine. Amounts of incorporation were examined by SDS-PAGE and fluorography.

To examine tissue specific synthesis of hsp's fish were transferred from $25^{\circ} \mathrm{C}$ to sublethal water temperatures of $28,31,32,33$, and $34^{\circ} \mathrm{C}$ for $1 \mathrm{hr}$. Control minnows were maintained at $25^{\circ} \mathrm{C}$. Brain $(39.0 \pm 15.2 \mathrm{mg})$, gill $(45.9 \pm$ $7.8 \mathrm{mg})$ and striated muscle $(49.5 \pm 3.4 \mathrm{mg})$ tissues were dissected immediately and metabolically labeled with ${ }^{35} \mathrm{~S}$-methionine/cysteine. Gill and muscle samples included five replicates of three fish each. Two replicates of brain tissue of five fish each were obtained. After metabolic labeling samples were homogenized, and proteins were separated by SDS-PAGE and fluorographed.

To examine the temperature range at which an individual tissue can synthesize hsps muscle tissue was exposed in vitro to a range of temperatures at three degree intervals from 25 to $43^{\circ} \mathrm{C}$ for $1 \mathrm{~h}$. Each treatment had three replicates. After the heat shock treatment, samples were metabolically labeled and subjected to SDS-PAGE and fluorography.

Gill, muscle and brain tissue were incubated at $25^{\circ} \mathrm{C}$ for $2 \mathrm{hr}$ in $125 \mu \mathrm{L}$ of

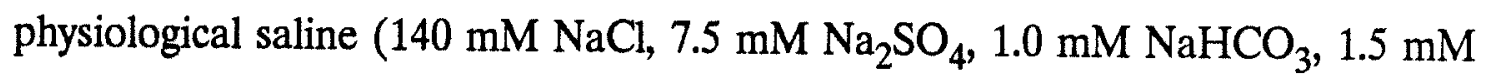
$\mathrm{CaSO}_{4}, 1.0 \mathrm{mM} \mathrm{MgCl}_{2}, 3.0 \mathrm{mM} \mathrm{KCl}, 0.5 \mathrm{mM} \mathrm{NaH}_{2} \mathrm{PO}_{4}, 0.5 \mathrm{mM}$ tris) which contained $5.5 \mathrm{mM}$ glucose and $1 \mu \mathrm{Ci} / \mu \mathrm{L}{ }^{35} \mathrm{~S}$-methionine/cysteine (Translabel, ICN Biomedicals). Incorporation of radioactive amino acids were halted by freezing the samples at $-80^{\circ} \mathrm{C}$. 
Metabolically labeled samples were rapidly thawed and centrifuged at $13,000 \mathrm{xg}$ at $4^{\circ} \mathrm{C}$ for $30 \mathrm{~min}$. The supernatant was discarded, and the tissue was rinsed in saline. The tissue was suspended in $150 \mu \mathrm{L}$ of tris buffer $(150 \mathrm{mM}$ Tris$\mathrm{HCl}, \mathrm{pH} 7.8,1 \mu \mathrm{M}$ phenylmethylsulfonylfluoride) at $4^{\circ} \mathrm{C}$, homogenized for $45 \mathrm{sec}$ with an Overhead Stirrer (Wheaton Instruments), and sonicated for $45 \mathrm{sec}$ with a Sonifier Cell Disruptor (Branson). Samples were centrifuged at $13,000 \mathrm{x}$ a at $4^{\circ} \mathrm{C}$ for $30 \mathrm{~min}$, and the pellet was discarded. Protein concentration was determined by the method of Bradford (1976), and samples were frozen at $-80^{\circ} \mathrm{C}$.

Samples containing $30 \mu \mathrm{g}$ of total protein and molecular weight-standards (phosphorylase b, $97.4 \mathrm{kD}$; bovine serum albumin, $66.2 \mathrm{kD}$; ovalbumin, $45 \mathrm{kD}$; carbonic anhydrase $31 \mathrm{Kd}$; soybean trypsin inhibitor, $21.5 \mathrm{kD}$; and lysozyme, 14.4 $\mathrm{kD})$ were boiled in sample buffer and loaded onto SDS-polyacrylamide gels using the method described by Laemmli (1970). Fifteen percent gels were used for samples from the time to induction and recovery experiments and in vitro temperature response experiments. Gels used for the in vivo temperature response experiments were $12.5 \%$. After electrophoresis, the gels were impregnated with Enhance (New England Nuclear) and exposed to film for 6 days (Kodak XAR-5).

Molecular weights of sample polypeptides for each fluorogram were determined using a standard curve that was generated by plotting the $R_{f}$ of each standard protein against its molecular weight. Sample band molecular weights were then determined by finding their $R_{f}$ 's on the standard curve and reading the 
molecular weight from the ordinate.

Relative intensities of bands on the film were quantitated using a laser densitometer (Ultroscan 2202, LKB Instruments; McMullin and Hallberg, 1986). Peaks of identified hsp's from scans were integrated, and intensities were calculated with GELSCAN (LKB) software on an Apple IIe microcomputer interfaced with the densitometer (Fig. 1). The intensities were determined at a scan speed of $100 \mathrm{~mm} / \mathrm{min}$, and the values were measured at an absorbance of 2 . The actual intensities are arbitrary units such that a full scale peak height of 10 with full width at half maximum of 2.0 has an intensity of 1000 units (Griffen and Spalding, 1988).

Kruskal-Wallis nonparametric analysis of variance was used to test for significance between treatment effects (Zar, 1984). Comparisons to controls were determined by one-tailed Dunnett $\mathrm{T}$ tests on ranked data. Significance for all statistical analyses was $\alpha=0.05$. Data are graphically represented in threedimensional plots in order to illustrate intensity data for each of the heat shock proteins versus exposure time or temperature. Due to high variablity of ${ }^{35} \mathrm{~S}$ methionine/cysteine incorporation into some heat shock proteins, increased bar height should not be misconstrued as statistically significant. Results of all statistical comparisons are stated in the figure captions and results section. 

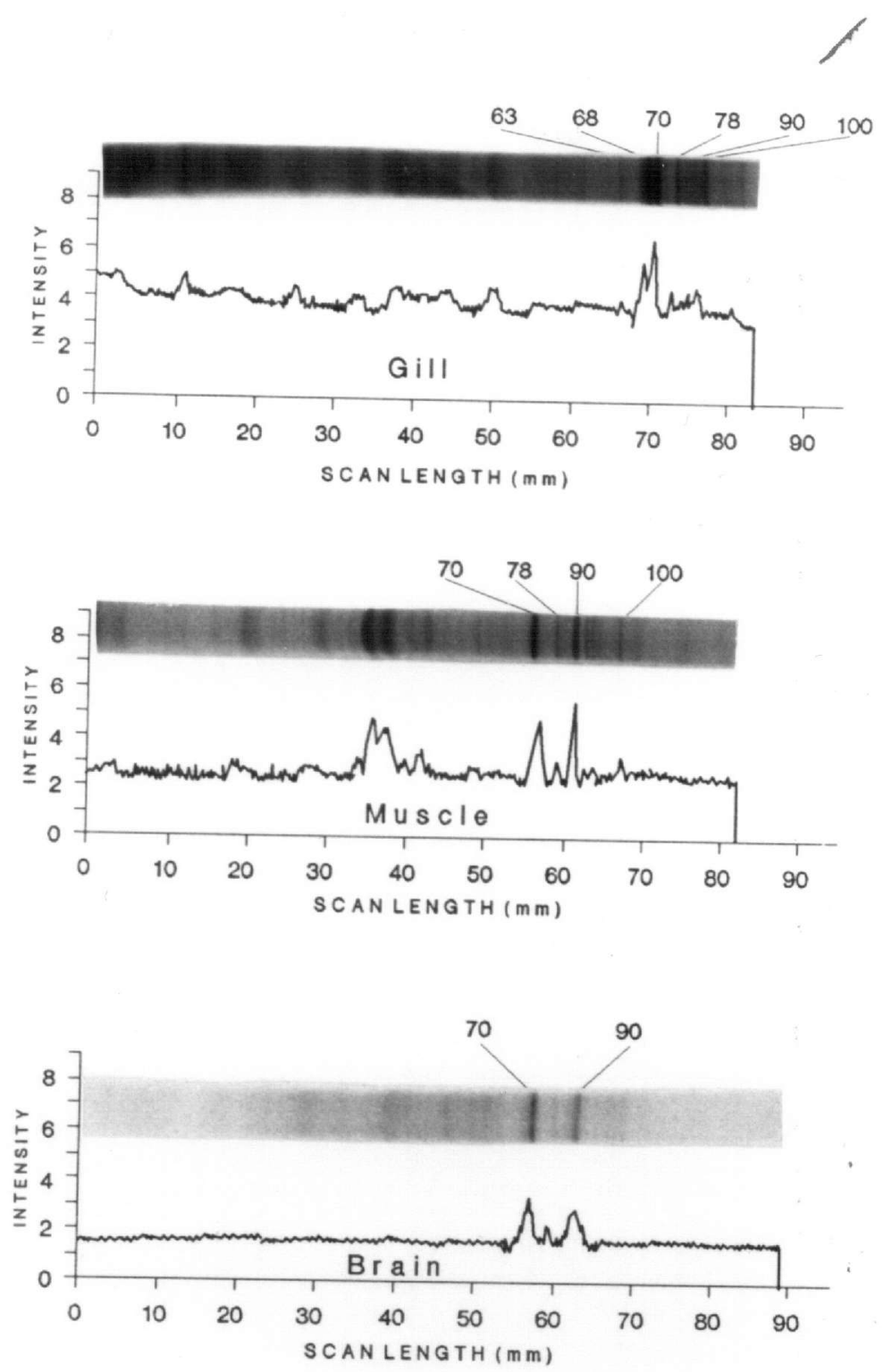

Figure 1. Overlying fluorograms with respective densitometer tracings from tissues of fish exposed to $32^{\circ} \mathrm{C}$ for $1 \mathrm{~h}$. The intensity scale is in arbitrary units. A. Gilloptically dense bands and underlying peaks corresponding to hsp's $63,68,70,78$, 90 , and 100 are indicated. B. Striated muscle- bands and peaks correspond to hsp's 70, 78, 90, and 100. C. Brain- bands and peaks correspond to hsp's 70 and 90. 
Results

In experiments to determine the maximum sublethal temperature, fish acclimated at $25^{\circ} \mathrm{C}$ were transferred to water at $33,34,35,36$, or $37^{\circ} \mathrm{C}$ and observed for $24 \mathrm{~h}$. Survival was significantly reduced at $35^{\circ} \mathrm{C}$ (Dunnett's $\mathrm{T}$ test, $\mathrm{p}$ $\leq 0.05$ ), and mortality was $100 \%$ at 36 and $37^{\circ} \mathrm{C}$. Therefore, the maximum sublethal temperature was defined as $34^{\circ} \mathrm{C}$.

Typical results from each of the experiments from which intensities were analyzed statistically are shown in Fig. 1. Each scan corresponds to tissues metabolically labeled with ${ }^{35} \mathrm{~S}$-methionine/cysteine, separated on an SDSpolyacrylamide gels and exposed to X-ray film for 6 days. Molecular weights (kD) of heat shock proteins (hsp's) are indicated above each fluorogram, and optically dense bands correspond to peaks of respective scans.

Fathead minnows exposed to $34^{\circ} \mathrm{C}$ water resulted in changes in translational pattern within 30 minutes of heat shock (Fig. 2A). Incorporation of ${ }^{35} \mathrm{~S}$ label into two hsps with apparent molecular weights of 70 and $90 \mathrm{kD}$ (hsp70 and hsp90, respectively) occurred at low rates at time zero and increased by 0.5 and 1 hours. Densitometric analysis showed that incorporation of radiolabel into hsp70 was significantly greater after $0.5 \mathrm{~h}$ of heat shock compared to zero hour levels (Fig. 2B; Dunnett's T test, $\mathrm{p} \leq 0.05$ ). After one hour of heat shock, both hsps (70 and 90) showed significantly increased incorporation above zero hour levels (Dunnett's $\mathrm{T}$ test, $\mathrm{p} \leq 0.05$ ). 


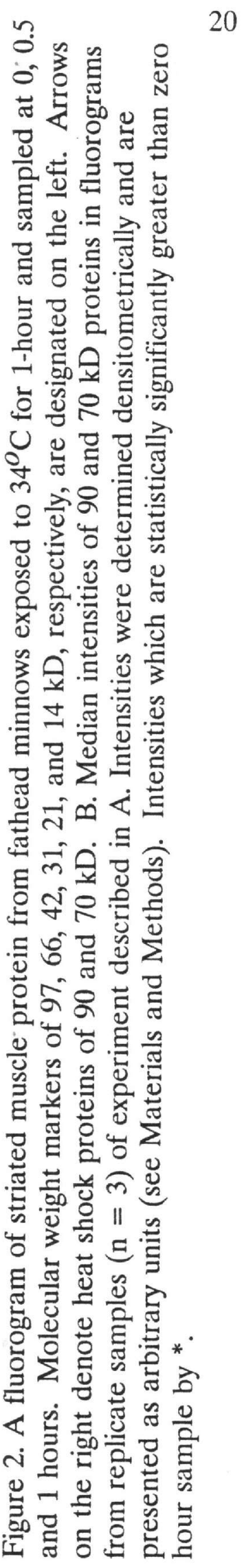



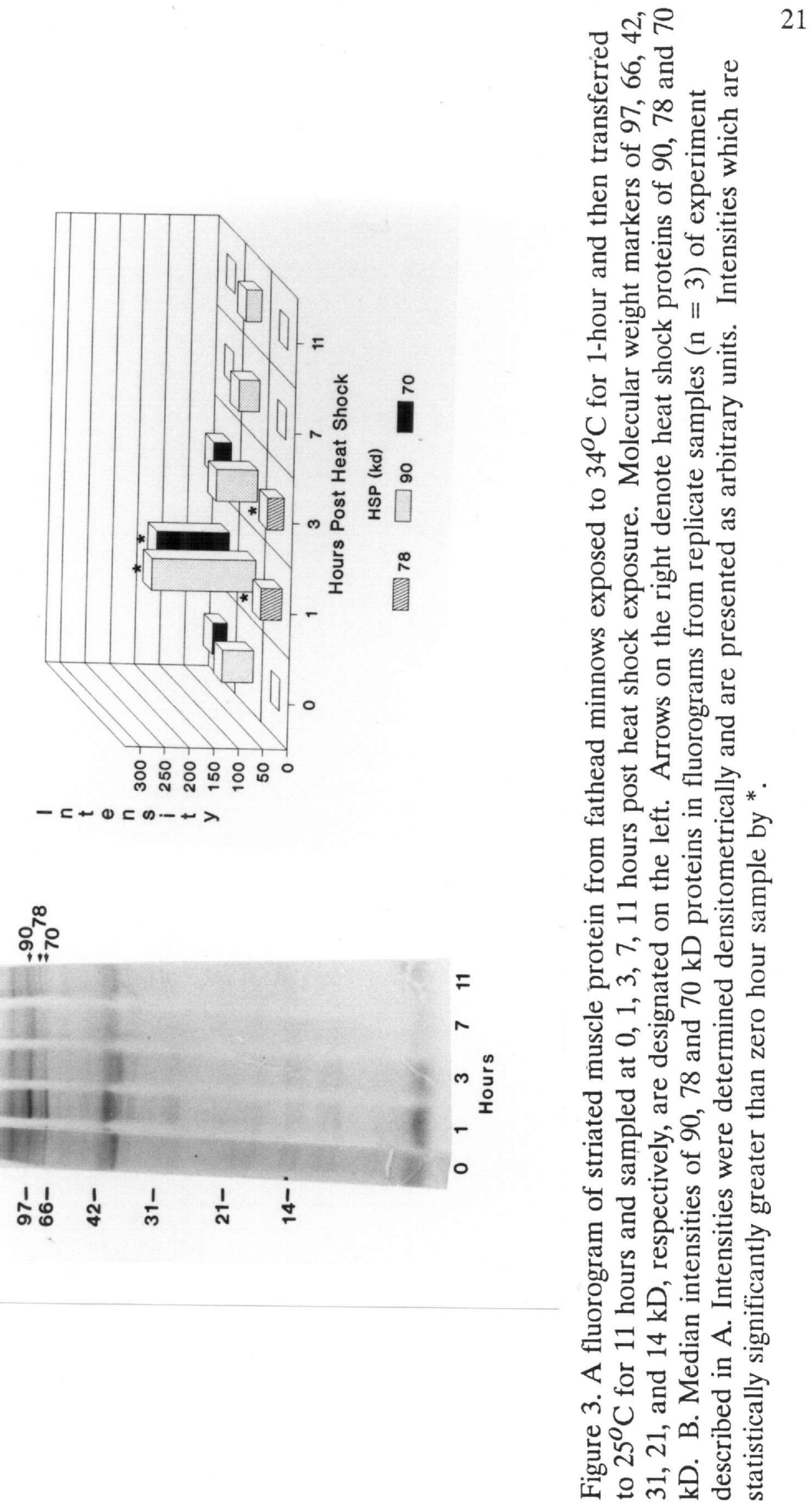
Two heat shock proteins, 70 and 90 , showed high level of incorporation at 1 hour post heat shock compared to the 0 hour samples (Fig. 3A). Incorporation of ${ }^{35} \mathrm{~S}$-methionine/cysteine into hsps decreased with increased time post heat shock, with the appearance of only hsp90 past the 3-h sampling period. Three $(70,78,90)$ of the four hsps found at the 1-hour interval still showed significantly greater incorporation rates compared to zero hour levels (Fig. 3A; Dunnett's T test, $\mathrm{p} \leq 0.05$ ). By three hours, post heat shock levels of hsps 70,90 and 100 had decreased to levels not significantly greater than 0-hour levels. Beyond 3-hours, synthesis and accumulation of all hsps had recovered to near or below zero-hour levels.

The heat shock response was tissue specific in fathead minnows exposed in vivo to a broad temperature range. Individual hsp's induced and their biosynthetic rates differed among muscle, gill and brain tissue. Furthermore, temperatures which induced the heat shock response and the maximum temperature at which each tissue synthesized hsp's were also tissue specific. The temperature range of the gill, as well as the number of hsp's elicited, was greatest followed by the muscle and then brain tissue. Synthesis of six hsp's were observed in gill, with apparent molecular weights of $100,90,78,70,68.3$, and $63.4 \mathrm{kD}$, hereafter referred to as hsp's 100, 90, 78, 70, 68, and 60 (Fig. 4A). Rates of ${ }^{35}$ S-methionine incorporation into hsp's 100,90 , and 78 increased from 28 to $33^{\circ} \mathrm{C}$, while 

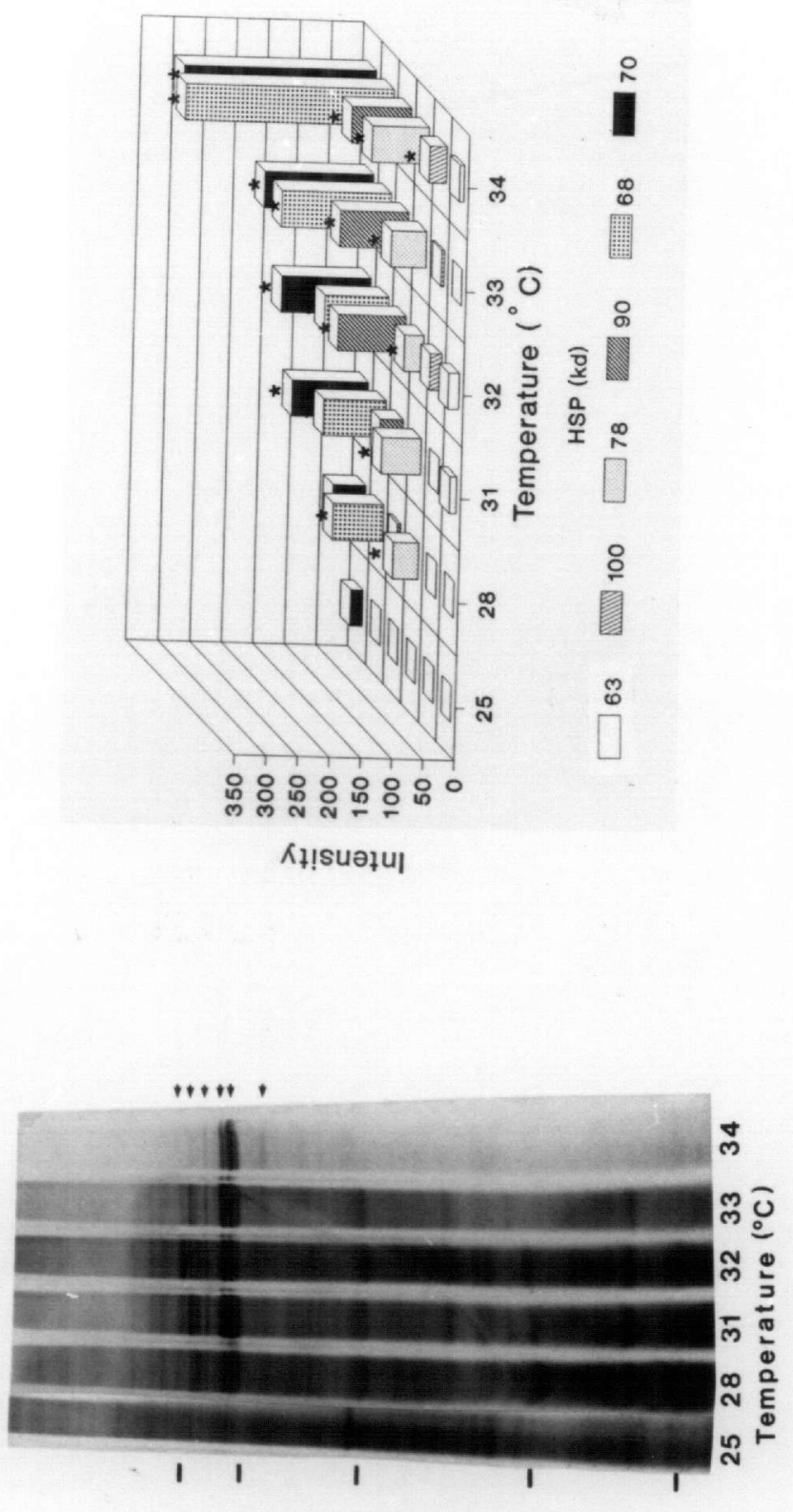

ஏ

능

บ D

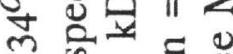

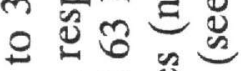

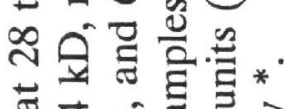

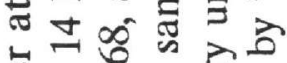

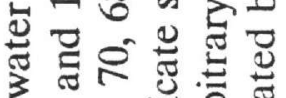

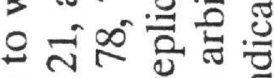

गิ์

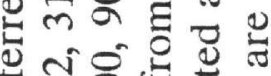

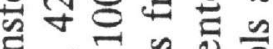

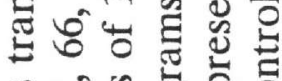

次.

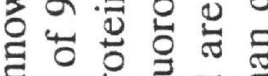

结豆导

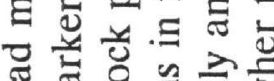

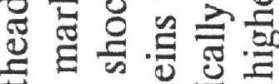

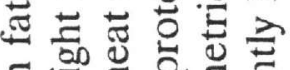

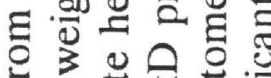

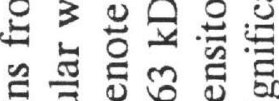

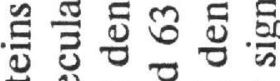

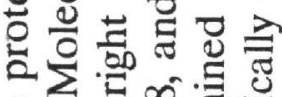

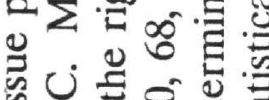

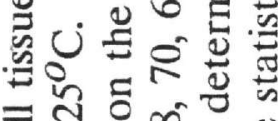

ㄷำ

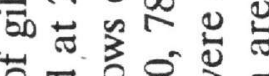

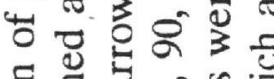

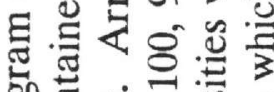

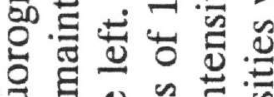

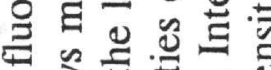

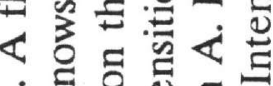

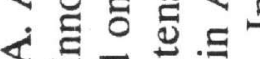

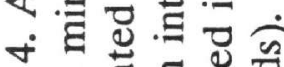

๑

올

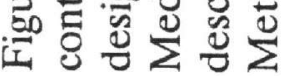



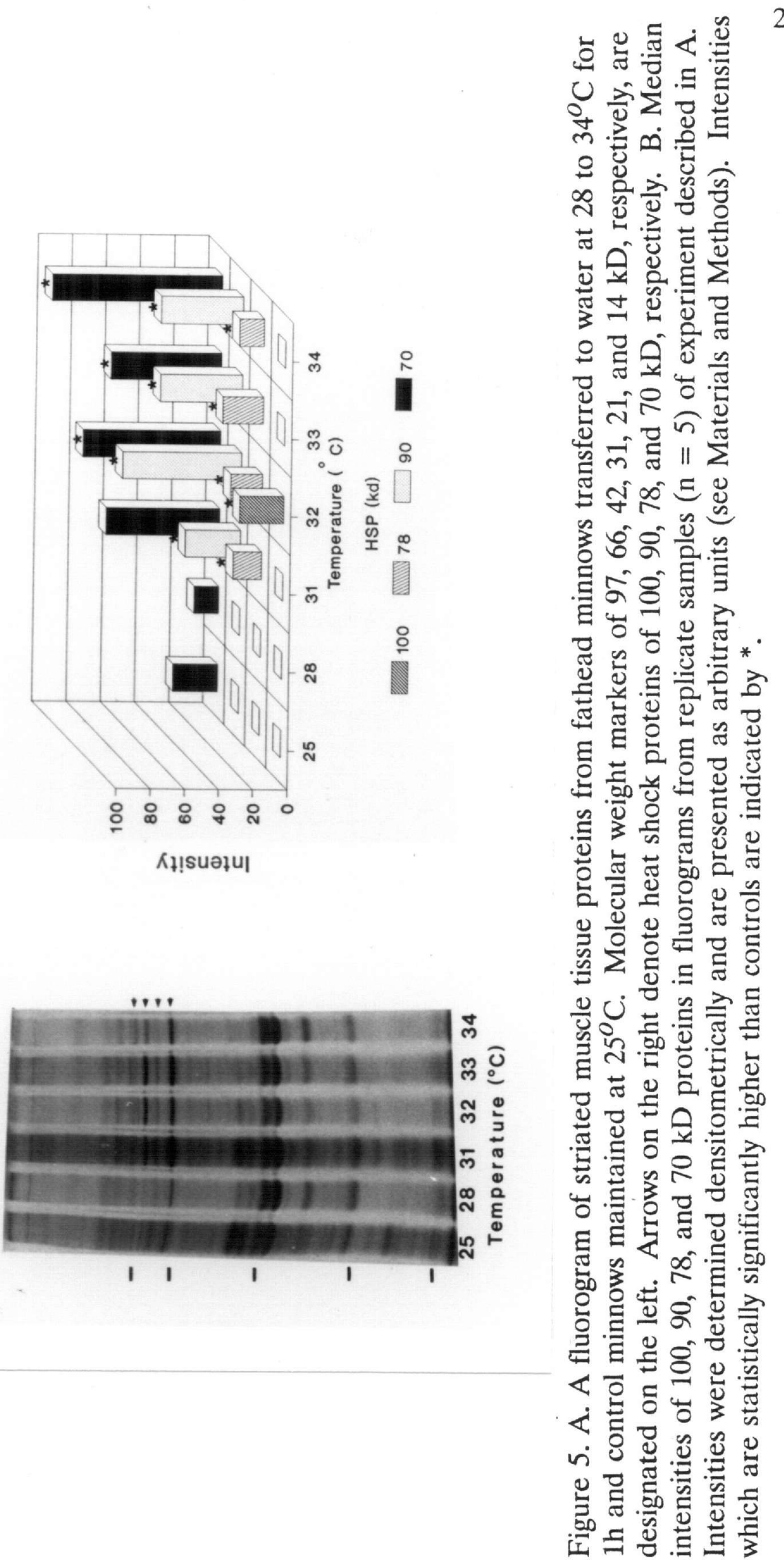

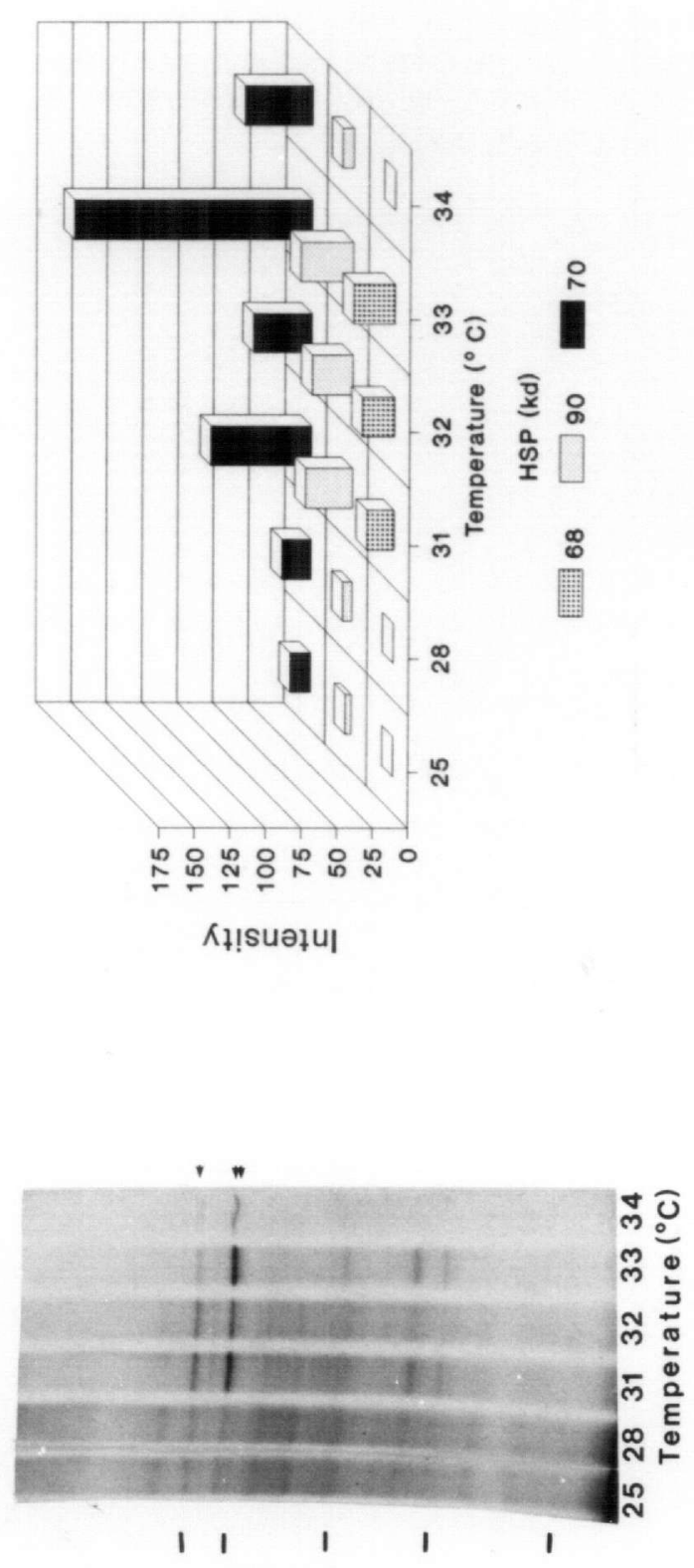

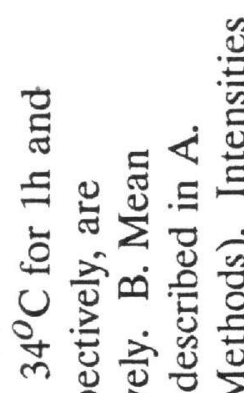

웅. ㄴ.

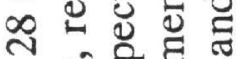

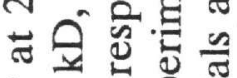

寸

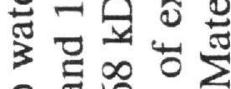

o ส

चีं

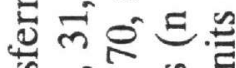

की 협 ์

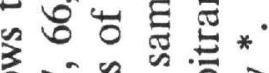

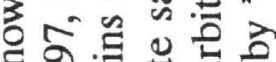

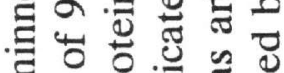
西的号的 马्⿹勹巳

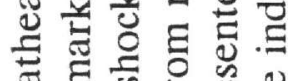
严击出芯

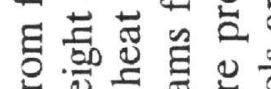
๓

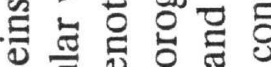

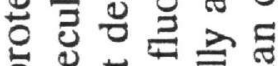

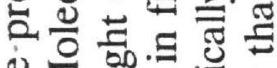

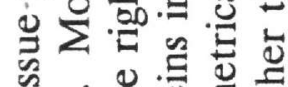

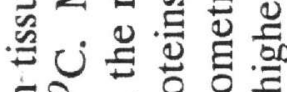

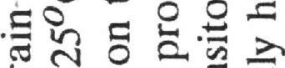
击为包 tै च 氙.气

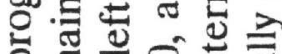

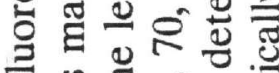
《

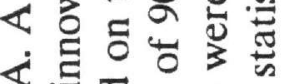

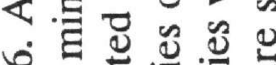

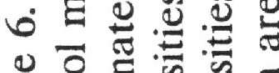
웅 대웜

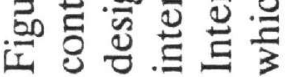


incorporation into hsp's 70 and 68 increased to $34^{\circ} \mathrm{C}$. Increased synthetic rates of a $60 \mathrm{kD}$ protein were found from 31 to $34^{\circ} \mathrm{C}$. The fluorogram shown indicates a relative decrease in translation rate for hsp's of 100,90 , and $78 \mathrm{kD}$ at $34^{\circ} \mathrm{C}$. However, statistical analysis of stress protein band intensities over all replicates showed that five of the six $(100,90,78,70$, and $68 \mathrm{kD})$ protein synthetic rates at $34^{\circ} \mathrm{C}$ were significantly greater than those of controls (Fig. 4B; Dunnett's $\mathrm{T}$ test, $\mathrm{p}$ $\leq 0.05)$. Significant increases above control $\left(25^{\circ} \mathrm{C}\right)$ rates of incorporation were observed for hsp's of 78 and $68 \mathrm{kD}$ from 28 to $34^{\circ} \mathrm{C}$, whereas the $70-\mathrm{kD}$ protein showed increased incorporation from 31 to $34^{\circ} \mathrm{C}$. A significantly increased rate of incorporation for the $100-\mathrm{kD}$ protein was found at $34^{\circ} \mathrm{C}$. Rates of incorporation into the 70- and 68-kD hsp's were greatest, followed by those of hsp's $90,78,100$, and $60 \mathrm{kD}$, respectively.

Four hsp's, 100, 90, 78 and 70, were found in striated muscle (Fig. 5A). Incorporation of radiolabel into hsp 70, although apparent at 25 and $28^{\circ} \mathrm{C}$, was greater at $31-34^{\circ} \mathrm{C}$. Rates of radiolabel incorporation for hsp's 100,90 , and 78 increased at 31 through $33^{\circ} \mathrm{C}$ and decreased at $34^{\circ} \mathrm{C}$. Densitometric scanning of five replicates for each treatment revealed that temperature significantly altered relative rates of synthesis for all four hsp's (Kruskal-Wallis, $p \leq 0.05$ ). In contrast to the fluorogram, when all replicates were taken into account, significant increases above control $\left(25^{\circ} \mathrm{C}\right)$ rates were observed for hsp's of 78 and $90 \mathrm{kD}$ from 31 to $34^{\circ} \mathrm{C}$ (Fig. 5B; Dunnett's $\mathrm{T}$ test, $\mathrm{p} \leq 0.05$ ). Significant increases in accumulation of hsp's relative to control occurred from 32 to $34^{\circ} \mathrm{C}$ for the $70-\mathrm{kD}$ 
hsp and only at $32^{\circ} \mathrm{C}$ for the $100-\mathrm{kD}$ hsp. Lack of radiolabel incorporation into the $100-\mathrm{kD}$ protein in three of the five replicates at 33 and $34^{\circ} \mathrm{C}$ and the use of the median as our quantile compromised its graphical representation. The heat shock response was dominated by hsp 70 followed by 90,78 , and 100 respectively.

The brain showed low incorporation of radiolabel into hsp's 70 and 90 at 25 and $28^{\circ} \mathrm{C}$ (Fig. 6A). Induction of the hsp response, as seen by increased band intensities corresponding to hsp's 90,70 , and 68 , began at $31^{\circ} \mathrm{C}$ and continued through $33^{\circ} \mathrm{C}$. At $34^{\circ} \mathrm{C}$, a sharp decline in hsp synthesis and accumulation was noted, with only hsp 70 being clearly visible. In addition, overall translational activity appeared to be markedly inhibited at $34^{\circ} \mathrm{C}$ as evidenced by the decrease in overall protein banding or background.

Only three hsp's could be quantitated in brain tissue, and statistical analysis was not possible because of the low number of replicates $(n=2$; Fig. $6 \mathrm{~B}$ ). Densitometric analysis indicated that hsp 70 dominated the heat shock protein response, followed by hsp's 90 and 68. Maximum intensities for all heat shock proteins occurred at $33^{\circ} \mathrm{C}$. A threefold decrease in radiolabel incorporation into hsp's 70 and 90 was found from 33 to $34^{\circ} \mathrm{C}$. In addition, hsp 68 was not quantifiable at $34^{\circ} \mathrm{C}$ due to low incorporation of label.

Increased synthesis and accumulation of three hsps (70,90, and 100) was observed in striated muscle from in vitro exposures (Fig. 7A). Incorporation of radiolabel into hsps 70 and 90 increased above control levels from 31 to $37^{\circ} \mathrm{C}$. Heat shock protein 100 was observed at $37^{\circ} \mathrm{C}$. At $40^{\circ} \mathrm{C}$, a sharp decline in hsp 


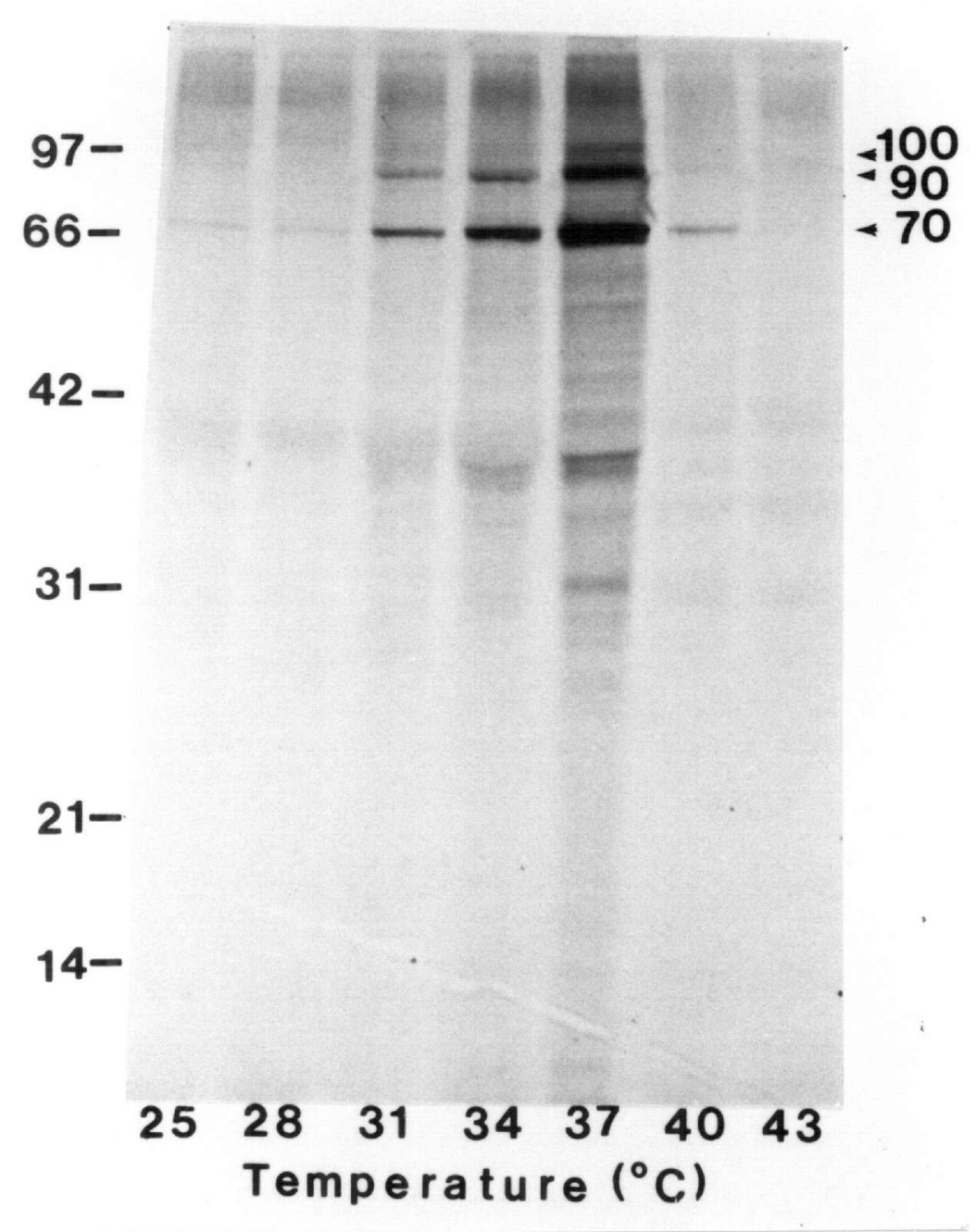

Figure 7A. A fluorogram of striated muscle proteins from tissue exposed in vitro to temperatures of $25,28,31,34,37,40$, and $43^{\circ} \mathrm{C}$ for 1 hour. Molecular weight markers of $97,66,42,31,21$, and $14 \mathrm{kD}$, repectively, are designated on the left. Arrows on the right denote heat shock proteins of 100,90 , and $70 \mathrm{kD}$, respectively. 


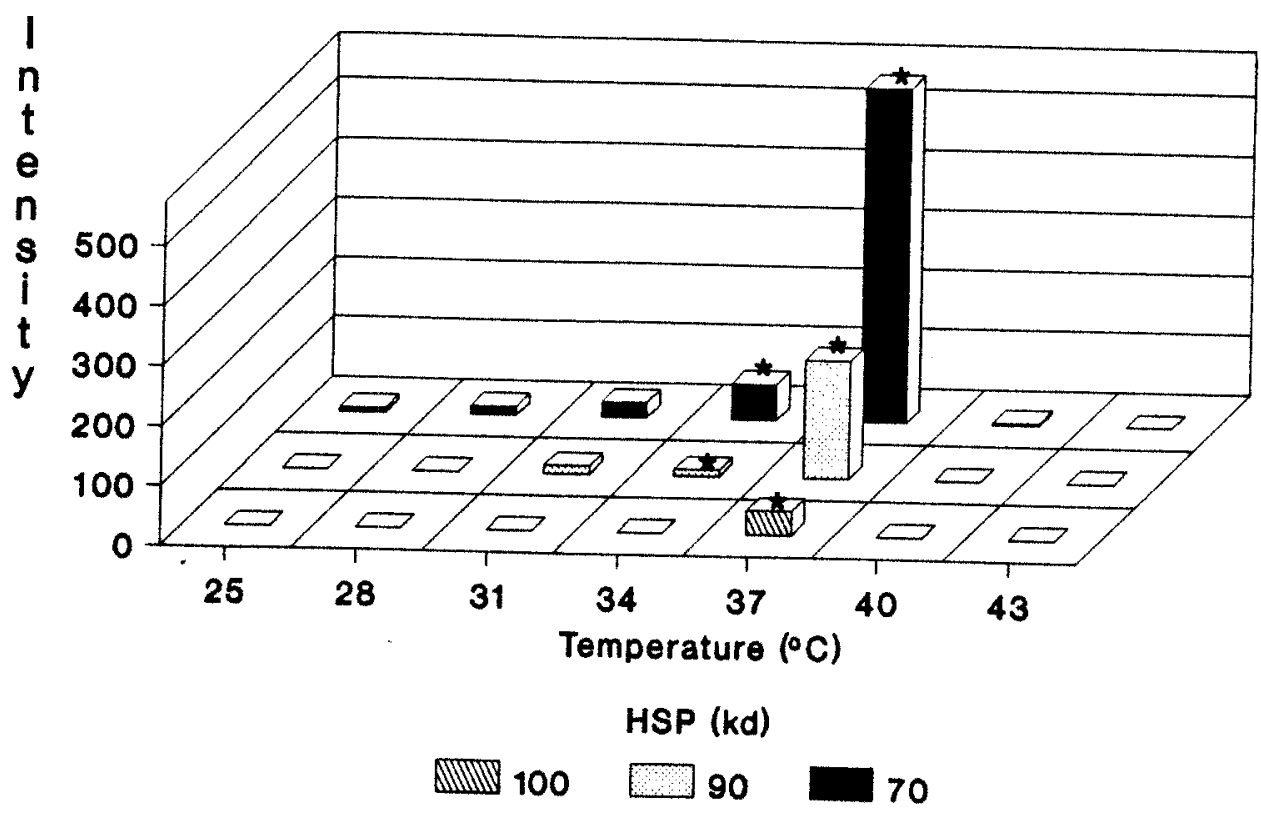

Figure 7B. Median intensities of 100,90 , and $70 \mathrm{kD}$ proteins in fluorograms from replicate samples $(n=3)$ of experiment described in Fig. 7A. Intensities were determined densitometrically and are presented as arbitrary units (see Materials and Methods). Intensities which are statistically significantly greater than controls, as determined by Dunnett's T test, are indicated by *.

synthesis and accumulation was observed, with only hsp70 being visible. No hsps were observed at $43^{\circ} \mathrm{C}$. Median densitometer readings showed that hsp70 clearly dominated the heat shock response, with significantly increased ${ }^{35} \mathrm{~S}$ methionine/cysteine incorporation at 34 and $37^{\circ} \mathrm{C}$ (Fig. 7B; Dunnett's T test, $\mathrm{p} \leq$ 0.05). Significant increases in radiolabel incorporation into hsp90 were also found at 34 and $37^{\circ} \mathrm{C}(\mathrm{p} \leq 0.05)$. Hsp100 was significantly induced at $37^{\circ} \mathrm{C}(\mathrm{p} \leq 0.05)$. Maximum intensities for all hsps occurred at $37^{\circ} \mathrm{C}$. No hsp was quantifiable at 40 and $43^{\circ} \mathrm{C}$ due to low incorporation of radiolabel. 
Discussion

Results of this study showed that fathead minnow (Pimephales promelas) survival was significantly decreased at $35^{\circ} \mathrm{C}$. This corroborates a previous report by Watenpaugh and Beitinger (1985) in which the critical thermal maxima for this species was found to be $35.12^{\circ} \mathrm{C}$. Striated muscle of fish exposed in vivo to the maximum sublethal temperature, $34{ }^{\circ} \mathrm{C}$, rapidly elicited the heat shock response. Within 0.5 hours, synthesis and accumulations of 70 and $90 \mathrm{kD}$ proteins were shown to be significantly increased. While comparative data from in vivo fish studies are not available, cultured chinook salmon embryonic cells have also been shown to elicit the heat shock response by 0.5 -h of heat stress (Gedamu et al., 1983). However, an in vivo heat shock study with laboratory rats showed that that maximum heat shock responses in brain, lung and skin occurred at 1 hour (Blake et al., 1990). The increased incorporation of radiolabel into hsps of the striated muscle was also shown to be reversible.

Fish placed back into $25^{\circ} \mathrm{C}$ water from 1 -h heat shock treatments, at $34^{\circ} \mathrm{C}$, showed a return to 0 -h levels of incorporation for all hsps by 7 h. Chinook salmon cells have also shown a full recovery from heat shock by 8 h (Heikkila et al., 1982). In addition, brain, lung, and skin of in vivo heat shocked rats showed a return to baseline by $3 \mathrm{~h}$ post heat shock (Blake et al., 1990).

Tissues of fathead minnows exposed in vivo to elevated temperatures responded by eliciting a suite of proteins whose synthesis and accumulation followed tissue specific patterns. Gill tissue produced the greatest number of hsp's 
(six) followed by striated muscle (four) and the brain (three). Molecular weights of hsp's synthesized in the gill were $100,90,78,70,68$, and $60 \mathrm{kD}$. Heat shock proteins $100,90,78$, and 70 were observed in the striated muscle and hsp's 90,70 , and 68 were induced in the brain. In comparison, several studies that have involved in vitro heat shock exposures with fish cell cultures have yielded similar, but not identical results. Fathead minnow epithelial cells exposed to $32^{\circ} \mathrm{C}$ elicited hsp 70 plus three low molecular weight hsp's of 39, 36, and $22 \mathrm{kD}$ (Merz and Laudien, 1987). However, our data did not show induction of any low molecular weight hsp's over the sublethal temperature range of this species. Tissue specificity or differences in experimental conditions might account for such differences.

Further, Koban et al. (1987) reported that hsp's 94, 91, 76, 74, and 65 were induced in catfish hepatocytes. Other researchers using Tilapia sp. ovary cells (Chen et al., 1988), chinook salmon embryonic cells (Heikkila et al,. 1982; Gedamu et al., 1983), rainbow trout hepatoma (Misra et al., 1989) and fibroblast cells (Mosser et al., 1986) have not only shown high and medium molecular weight hsp's (100-60 kD) but also low molecular weight hsp's (42-19 kD) upon hyperthermic exposures.

Striated muscle tissue exposed in vitro elicited significant increases in hsp syntheses at 34 and $37^{\circ} \mathrm{C}$. Yet little or no incorporation was evident at 40 and $43^{\circ} \mathrm{C}$. Correspondingly, Schmidt et al. (1984) found that fathead minnow epithelial cell viability did not decrease significantly until $41^{\circ} \mathrm{C}$ exposures, well 
beyond the thermal limits of the whole organism. This supports previous trends noted by Ushakov (1964) and Lagerspetz (1987) in which thermal sensitivity was found to be greatest at the organismal level and lowest at the cellular level. Tissue specific induction patterns of hsp's have been reported in other organisms as well. For example, connective tissue (blood and muscle cells) of the mollusc, Aplysia californica, elicited hsp's 110, 90, and 70 upon in vitro heat shocks of $34^{\circ} \mathrm{C}$, while ganglion cells produced only hsp's 110 and 70 (Greenberg and Lasek, 1985). Similar neuronal heat shock responses have been seen in the laboratory rat and American cockroach (Periplaneta americana). Heat shock proteins 110,74 , and 64 were synthesized in optical nerves of the laboratory rat, and hsp's 83,70 , and 68 were synthesized in the nerve cords of the cockroach (Tytell and Barbe, 1987; Ruder et al., 1989). Although few multi-tissue studies have been undertaken with poikilotherms, a study on the lungless salamander, Desmognathus ochrophaeus, brain and muscle tissues did not show any differences in the heat shock response (Rutledge et al., 1987).

Two explanations for the more complex heat shock response of the gill as compared to that of brain and striated muscle are plausible. First, only the gill is directly exposed to heated water, whereas the other two tissues experience increased temperatures via diffusion from surrounding tissues. A second explanation is that the evolution of the gill as a highly membranous gas and ion exchange organ required increased protective mechanisms such as the heat shock proteins for membrane structural integrity under constantly changing exposures, 
i.e. temperatures, gases, ions, $\mathrm{pH}$, turbidity, etc. In addition, the greater variety of heat shock proteins in the gill may also be indicative of the many cell types and functions performed versus those in brain and muscle. At present, nothing is known about the contribution of cell types to the overall gill hsp response.

In the present study, temperature ranges over which hsp's were synthesized were also highly tissue specific. Gill tissue had the broadest range and showed significantly increased hsp syntheses at $28^{\circ} \mathrm{C}$, reaching maximum rates at $34^{\circ} \mathrm{C}$, whereas striated muscle showed significantly increased hsp syntheses at $31^{\circ} \mathrm{C}$ and reached maximum rates at $34^{\circ} \mathrm{C}$. In contrast, brain tissue showed increased hsp syntheses at $31^{\circ} \mathrm{C}$, reached maximum rates at $33^{\circ} \mathrm{C}$, and showed a marked decrease at $34^{\circ} \mathrm{C}$. These observed differences in the heat shock protein response suggest that, of the three tissues examined, brain is the most sensitive. The temperature range which elicits the heat shock response in fathead minnow striated muscle was similar to that of connective tissue in a mollusc, Aplysia (Greenberg and Lasek, 1985). Both showed significantly increased synthetic rates of hsp 70 at $31^{\circ} \mathrm{C}$, and both showed maximum responses at the maximum temperatures tested, $34^{\circ} \mathrm{C}$ for minnow muscle and $37^{\circ} \mathrm{C}$ for mollusc connective tissue. In an in vitro heat shock exposure, as were the Aplysia exposures, we found that striated muscle elicited its maximum heat shock response at $37^{\circ} \mathrm{C}$.

Similarly, the minimum temperature required for induction of hsp's in fish brain and mollusc ganglion was $31^{\circ} \mathrm{C}$. However, the ganglion showed a heat shock protein response through $37^{\circ} \mathrm{C}$, whereas the maximum response was $33^{\circ} \mathrm{C}$ in the 
brain. The heat shock response in brain also may be explained by data suggesting that axons have low synthetic abilities for hsp's and, therefore, require extracellular hsp inputs, specifically from glial cells, to repair damage incurred from hyperthermic exposure (Hightower and Guidon, 1989).

The data from my research demonstrated specificity of hsp induction patterns for each tissue, there appears to be a common pattern with all tissues eliciting hsp's 70 and 90 upon in vivo hyperthermic exposure. Much is now known about the function of these two hsp's in normal cellular metabolism. Heat shock protein 70 has been shown to have at least three functions, multimeric protein assembly, unfolding for translocation, and disaggregation of protein aggregates (Craig, 1989; Rothman, 1989; Welch; 1990). These functions are also thought to facilitate repair of proteins and protein complexes associated with common and critical physiological processes, and thus protect cells from heat induced damage. Whereas, hsp 90 has been shown to be associated with steroid receptors (Baulieu, 1989), the aryl hydrocarbon hydroxylase receptor (Perdew, 1988), and a translational initiation factor kinase (Rose et al., 1989). Thus, hsp 90 is intimately involved in both transcriptional and translational events.

The fact that the heat shock protein response differs among tissues supports the hypothesis that thermal limits of an organism are governed by certain tissues more than others. The maximal hsp responses of gill and muscle at the maximum sublethal heat shock temperature negate their suspect as "weak link" candidates. However, the coincident decreases in hsp synthesis and accumulation 
in the brain with that of the fish's upper thermal limit supports earlier hypotheses that the central nervous system governs the thermal limits of poikilotherms.

Sensitivity of brain tissue to elevated temperatures may be the result of the limited capacity of the brain to synthesize hsp's and supporting the suggestion that neural tissue might be a rate limiting tissue in organismal survival. Without an appropriate cellular protective mechanism, such as heat shock proteins, cellular function and integrity may be compromised along with the organism's survival. 


\title{
CHAPTER III
}

\section{CHEMICAL EXPOSURES}

\author{
Introduction
}

In a monitoring situation, an ideal biomarker would enable one to assess the level of biotic stress and the causative agent(s). That is, to assess both contaminant effects and exposure. However, at this time there is no known single biochemical indicator that can provide information on both types of assessments. Traditionally, effects assessments have been based at the organismal level. Thus, if biomarkers are to be useful effects indicators they must be calibrated to toxicity endpoints such as growth, reproduction, and survival. As mentioned by Bouk (1984), few of the biochemical indicators lend themselves to field application, mainly because calibration is lacking. Therefore, there is a need for a direct and sensitive measure (biomarker) for evaluating general stress in organisms from both laboratory and natural populations. Such a measure would have great predictive value and wide application if it were based on the molecular mechanisms in stress physiology (Jenkins and Sanders, 1986). However, several biochemical indicators have potential to serve as markers of exposure to specific chemical classes. For example, there is a sizeable literature base supporting the use of cholinesterases as indicators of carbamate and organophosphate pesticide exposure (Williams and Sova, 1966; Coppage, 1972; Coppage et al., 1975; Coppage, 1977; 
Ansari and Kumar, 1984). Cytochrome P-450's have shown excellent potential as biomarkers of PAH, PCB, and dioxin exposure (Melancon et al., 1987; Stegeman et al., 1987; Hahn et al., 1989). In addition, delta-aminolevulinic acid dehydratase activity (Hodson, et al., 1984), heme oxygenase (Ariyoshi et al., 1990; Mitani et al., 1990), and metallothionein (Jenkins et al., 1982; Sanders et al., 1983) have shown potential to serve as biomarkers of metal exposure.

The stress protein response (SPR) has potential to serve as both an indicator of contaminant induced effects and exposure. The products of the SPR perform various tasks such as protein folding, multimeric protein assembly, receptor interactions and heme catabolism to name a few (Craig, 1989; Keyse and Tyrell, 1989; Rothman, 1989; Beckmann et al., 1990; Schlesinger, 1990). Synthesis of sp70 has been shown to be induced by a wide variety of stressors (i.e. hyperthermia, sulfhydryl-reactive agents, metals, peroxide, dinitrophenol, steroids, and viral infection; Nover, 1984; Schlesinger, 1990). Thus, sp70 has been proposed to serve as a general stress indicator (Sanders, 1990).

Increased synthesis and accumulation of other stress proteins may be indicative of chemical specific stress. For instance, synthesis of low molecular weight stress proteins, $20-40 \mathrm{kD}$, have been shown to be induced by oxidizing agents, arsenite, and heavy metal exposure (Shibahara et al., 1987; Keyse and Tyrell, 1989; Ariyoshi et al., 1990; Mitani et al., 1990). Thus, the SPR has potential to also serve as a chemical specific indicator. Furthermore, by examining the types of stress proteins elicited and their level of increase it is possible that 
one could assess both level of exposure and effects.

To test the hypothesis that the SPR may serve as an indicator of both exposure and effects, a series of chemical experiments were conducted. The objectives of this research endeavor were three-fold: 1) to determine the concentration-responsiveness of the SPR; 2) calibrate the SPR to traditional toxicity measures (i.e. percent mortality, LC50, and LC1); and 3) determine the tissue and chemical specificities of the SPR.

To accomplish this, fathead minnows were exposed, via standard $96-\mathrm{h}$ toxicity tests, to four different chemicals, each with a different and well defined mode of action. Chemicals used were sodium arsenite, sodium chromate, lindane, and diazinon.

Thus far, the principle hypothesis governing the elicitation of the SPR is the denaturing of native proteins (Ananthan et al., 1986; Munro and Pelham, 1986; Beckmann et al., 1990). Of the four chemicals chosen two (arsenite, chromate) have demonstrated the ability to denature proteins, albiet through different mechanisms. Arsenite has repeatedly been shown to elicit the SPR in practically all types of cells (Hiwasa and Sakiyama, 1986; Duncan and Hershey, 1987; Kapoor and Lewis, 1987). Although its classically defined mode of action is its inhibition of oxidative pathways (Webb, 1966), it is thought to induce the SPR by binding to thiol groups of proteins thus, effectively denaturing them (Munro and Pelham, 1986). Chromate has been found to denature proteins via oxidation (Nieboer and Jusys, 1988). In addition, structural damage to fish gill due to 
chromate exposure has also been shown (Van der Putte et al., 1981). Thus, chromate might be expected to elicit the SPR, at least in the gill.

To my knowledge, the other two toxicants chosen (lindane and diazinon) have not been evaluated for their ability to induce the SPR. Both are neurotoxicants. Lindane inhibits the GABA-activated chloride channel (Matsumura and Ghiasuddin, 1983; Woolley and Zimmer, 1986; Fishman and Gianutsos, 1987; Joy et al., 1987; Ogata et al., 1988) whereas diazinon inhibits cholinesterase activity (Matsumura, 1985; Murphy, 1986; Durham, 1987). Therefore, elicitation of the SPR by either of these chemicals, most likely, would not be able to be explained by classical SPR and mode of action definitions but through other mechanisms, such as disruption of the membrane lipidic matrix (Demael et al., 1987) or inhibition of oxidative processes (Rao and Rao, 1979; Vijayalakshmi, 1980; Basha et al., 1984).

Methods, results, and discussion subsections for each respective toxicant (arsenite, chromate, lindane, and diazinon) are presented in the following sections. 
Arsenite Exposures

Materials and methods

Ninety-day-old fathead minnows (Pimephales promelas) were obtained from a culture located at the University of North Texas. Fish used for the study were acclimated to $25^{\circ} \mathrm{C}$ for at least 7 days and a $16 \mathrm{~L}: 8 \mathrm{D}$ photoperiod and were fed frozen brine shrimp twice daily to satiation.

An initial range-finding experiment was carried out to determine a range of sodium arsenite concentrations suitable for a definitive LC50 test and to determine times to first signs of intoxication. Aquaria (19L) were filled to $10 \mathrm{~L}$ with nominal concentrations of $0,5,10,15,25$, and $35 \mathrm{mg} \mathrm{As} / \mathrm{L}$. Each treatment was replicated three times. Fish ( 3 to 5) were placed into each treatment replicate and observed for onset of intoxication. Fish exposed to $25 \mathrm{mg} \mathrm{As} / \mathrm{L}$, showed first signs of intoxication by $8-10 \mathrm{~h}$. Signs of intoxication followed a behavioral progression where fish first displayed lethargy with coughing, followed by erratic swimming at the water/air interface, and finally a loss of equilibrium.

To determine the length of time required for stress protein induction, fish were exposed to $25 \mathrm{mg} \mathrm{As} / \mathrm{L}$ and sampled at $0,2,4,6,8$, and $10 \mathrm{~h}$. Two replicates of three fish each were sampled at each time interval. Immediately after sampling, fish were sacrificed and gill tissue (mean wet weight \pm standard deviation $=50.6 \pm 3.7 \mathrm{mg}$ ) was dissected and pooled within each treatment replicate. Tissues were metabolically labeled for $2 \mathrm{~h}$ with ${ }^{35} \mathrm{~S}$-methionine/cysteine. Incorporation of label into proteins was examined by SDS-polyacrylamide gel 
electrophoresis (SDS-PAGE) and fluorography. Resulting fluorograms demonstrated that stress proteins observed within the 10 - $h$ treatment period were maximally induced between 6 and $10 \mathrm{~h}$. Thus, $8 \mathrm{~h}$ was selected as the sampling time to examine the SPR in the subsequent definitive 96-h toxicity test.

To assess the concentration range in which the gill and striated muscle synthesize stress proteins, fish were exposed to five different arsenite concentrations $(6.02 \pm 0.24 ; 9.59 \pm 0.05 ; 17.72 \pm 1.91 ; 26.66 \pm 1.91 ; 35.61 \pm$ $2.64 \mathrm{mg} \mathrm{As} / \mathrm{L}$ ), plus control, and sampled at $8 \mathrm{~h}$. Each treatment was replicated five times. Thirteen fish were placed into each treatment replicate and three were subsampled at $8 \mathrm{~h}$ while the rest were exposed for $96 \mathrm{~h}$. Tissues of subsampled fish (gill $45.8 \pm 6.6$; striated muscle $47.8 \pm 4.9 \mathrm{mg}$ ) destined for metabolic labeling, were treated as in the induction study. Time to mortality was recorded every $24 \mathrm{~h}$. Metabolic labeling, sample preparation, SDS-PAGE, and quantitation were performed using methods described in the heat shock experiment. X-ray films used for densitometric quantitation were exposed to gels for $3 \mathrm{~d}$.

Proteins from striated muscle tissue of $96-\mathrm{h}$ toxicity test survivors were separated on a $12.5 \%$ SDS-polyacrylamide gel and transferred to nitrocellulose using a transfer buffer containing $1 \%$ SDS, $0.192 \mathrm{M}$ glycine in $0.025 \mathrm{M}$ tris and $20 \%$ methanol $(\mathrm{v} / \mathrm{v}), \mathrm{pH} 8.3$. The gels were subjected to $30 \mathrm{~V}$ for $15 \mathrm{~h}$ at $4^{\circ} \mathrm{C}$. The nitrocellulose was then blocked for $30 \mathrm{~min}$ in tris buffered saline (TBS) containing $3 \%$ bovine serum albumin (BSA), $0.5 \%$ Tween (TTBS) and $0.01 \%$ thimerosal. 
The nitrocellulose was probed with one of two antibodies, a polyclonal antibody $(\mathrm{Ab})$ raised against hsp60 from the moth Heliothis (generously provided by S. Miller; Miller, 1987) and a monoclonal $A b$ raised against hsp72/73 from HeLa cells (generously provided by W. Welch; Riabowol et al., 1988). Blots were incubated at room temperature with hsp60 and hsp 72/73 antibodies for $90 \mathrm{~min}$ and rinsed several times with TBS containing $0.5 \%$ Tween-20 (TTBS). The hsp60 $\mathrm{Ab}$ blots were incubated with a second $\mathrm{Ab}$ of goat anti-rabbit alkaline phosphatase (AP) conjugated antibody (BIORAD) for $90 \mathrm{~min}$, whereas hsp 72/73 Ab blots utilized a goat anti-mouse $\mathrm{Ab}$ for the second antibody. The blots were washed several times with TTBS and TBS and incubated with the substrates 5-bromo 4chloro 3-indoyl phosphate p-toluidine salt and p-nitro blue tetrazolium chloride (BIORAD) to visualize bound antibody.

All exposures used dechlorinated Denton City tap water that had the following mean characteristics: alkalinity $100 \mathrm{mg} \mathrm{CaCO} / / \mathrm{L}$; hardness $120 \mathrm{mg}$ $\mathrm{CaCO}_{3} / \mathrm{L}$; and conductivity 300 umhos. Dissolved oxygen and $\mathrm{pH}$ were monitored for each test. Dissolved oxygen ranged from 4.6 to $9.0 \mathrm{mg} \mathrm{O}_{2} / \mathrm{L}$ while $\mathrm{pH}$ ranged from 7.2 to 7.5 over all concentrations. Arsenic concentrations were determined using a Perkin Elmer atomic absorption spectrophotometer (EPA method 206.2). Concentration effects on mortality were determined by parametric analysis of variance on arcsine transformed percent mortality data. Comparisons to controls were made by one-tailed Dunnett T tests. The LC50 and LC1 were determined by probit analysis. Stress protein intensities were analyzed 
nonparametrically due to heteroscedacity. Kruskal-Wallis analysis of variance on ranked intensity data was used to determine the significance of treatment effects $($ alpha $=0.05)$ on specific stress protein intensities. Comparisons to controls were determined by one-tailed Dunnett $\mathrm{T}$ tests on ranked data. Spearman rank correlations were used to compare percent mortality to stress protein intensities. Data are presented in three-dimensional plots in order to fully illustrate intensity data for each of the stress proteins versus arsenic concentration. Due to the high variability of ${ }^{35} \mathrm{~S}$-methionine/cysteine incorporation into some stress proteins, increased bar height above that of the controls should not be interpreted as being necessarily statistically significant. All statistical comparisons are stated in the Results.

Results

Arsenite treatments caused significant changes in mortality (parametric AOV, $\mathrm{p}=0.0001)$. Percent mortality was zero percent in controls, $29.8 \%$ at 6.0 $\mathrm{mg} \mathrm{As} / \mathrm{L}$, and 41.6, 76.0, 93.2, and 97.8\% at 9.6, 17.7, 26.7, and $35.6 \mathrm{mg} \mathrm{As} / \mathrm{L}$, respectively. A Dunnett's T test revealed that all arsenite treatments (6.0, 9.6, 17.7, 26.7, and $35.6 \mathrm{mg} \mathrm{As} / \mathrm{L}$ ) caused significant increases in mortality, compared to controls $(\mathrm{p} \leq 0.05)$. Probit analysis determined the LC50 to be $9.9 \mathrm{mg} \mathrm{As} / \mathrm{L}$ and $\mathrm{LC} 1$ to be $1.8 \mathrm{mg} \mathrm{As} / \mathrm{L}$.

Gill tissue of fathead minnows exposed to $25 \mathrm{mg}$ As/L responded by eliciting the stress response. Six proteins with apparent molecular weights of 20 , 
30, 40, 70, 72, and $74 \mathrm{kD}$ were observed (Figure 8). Radiolabel incorporation into proteins increased beyond 0 - $\mathrm{h}$ rates by $2 \mathrm{~h}$ of exposure. Incorporation remained high throughout the $10 \mathrm{~h}$ exposure period. Maximum synthetic rates for the $30 \mathrm{kD}$ protein occurred at 4 and $6 \mathrm{~h}$. However, densitometric analyses of the other proteins $(20,40,70,72$, and $74 \mathrm{kD})$ showed that maximum rates occurred at 6,8 , and $10 \mathrm{~h}$ exposure. An $8 \mathrm{~h}$ exposure was, therefore, determined to be the appropriate sampling time for the concentration-response study. The goal was tocorrelate the synthesis of the stress proteins to an eventual effect, namely percent mortality.

The stress response was found to be tissue-specific in fish exposed to a range of arsenite concentrations. The specific stress induced proteins and their levels of radiolabel incorporation differed between gill and the striated muscle. Moreover, the range of concentrations required for the increased incorporation of ${ }^{35} \mathrm{~S}$-methionine/cysteine into similar molecular weight proteins was also tissue specific.

Increased radiolabel incorporation into six proteins $(20,30,40,70,72$, and 74) was observed in the gill (Figure 9A). A qualitative description of one of the replicate fluorograms shows that ${ }^{35} \mathrm{~S}$-methionine/cysteine incorporation into proteins of $20,40,72,74 \mathrm{kD}$ increased above control rates from 17.7 to $35.6 \mathrm{mg}$ $\mathrm{As} / \mathrm{L}$, and the $70 \mathrm{kD}$ protein showed an increase at $35.6 \mathrm{mg} \mathrm{As} / \mathrm{L}$. Statistical analyses of densitometric scans of all five replicates showed that sodium arsenite significantly altered incorporation into five of the six $(20,40,70,72$, and $74 \mathrm{kD})$ 


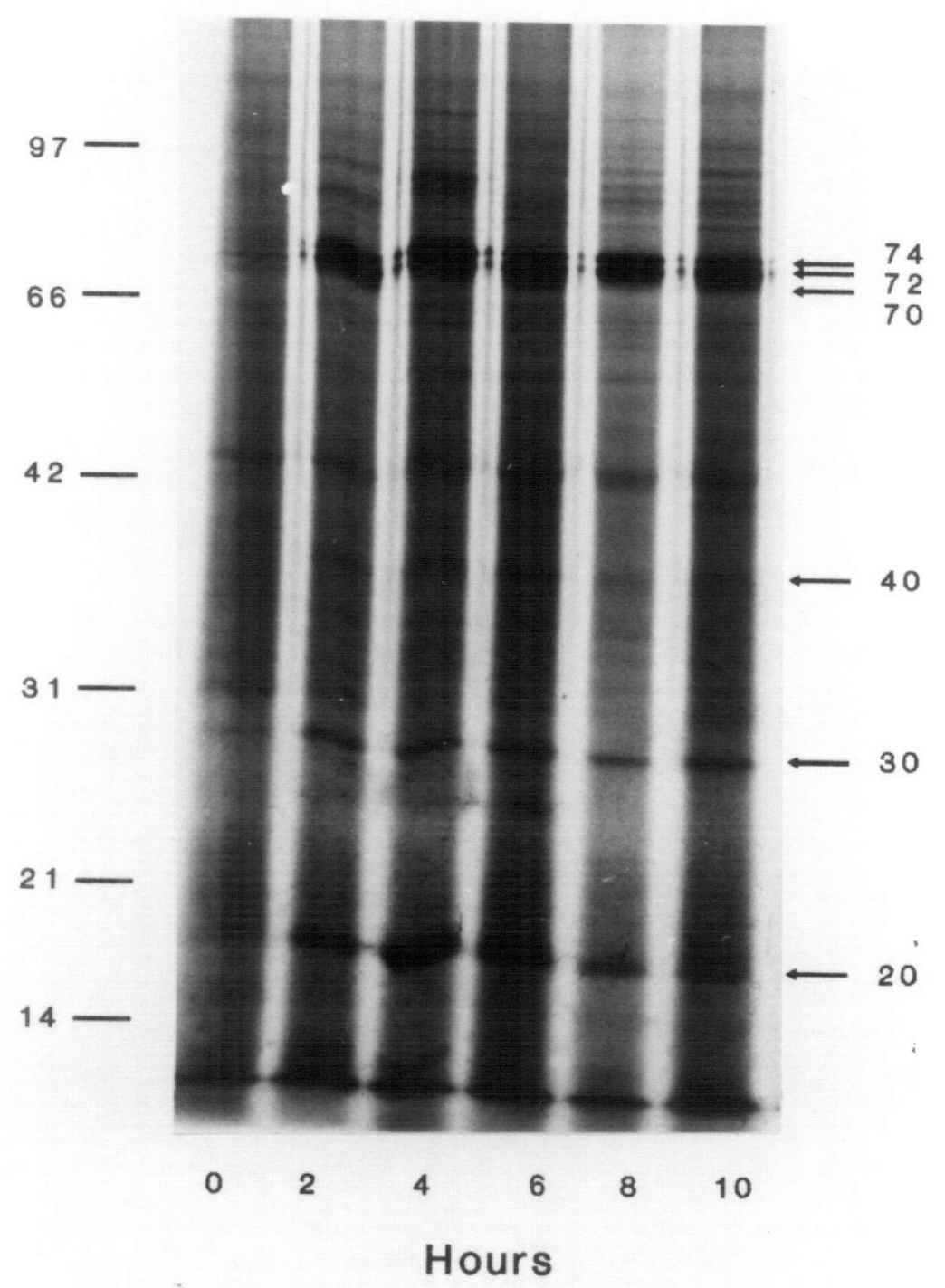

Figure 8. A fluorogram of gill tissue proteins from fish exposed to $25 \mathrm{mg} \mathrm{As} / \mathrm{L}$ for $0,2,4,6,8$, and $10 \mathrm{~h}$. Molecular weight markers are designated on the left. Arrows on the right denote proteins of 20,30, 40, 70, 72, and $74 \mathrm{kD}$. 


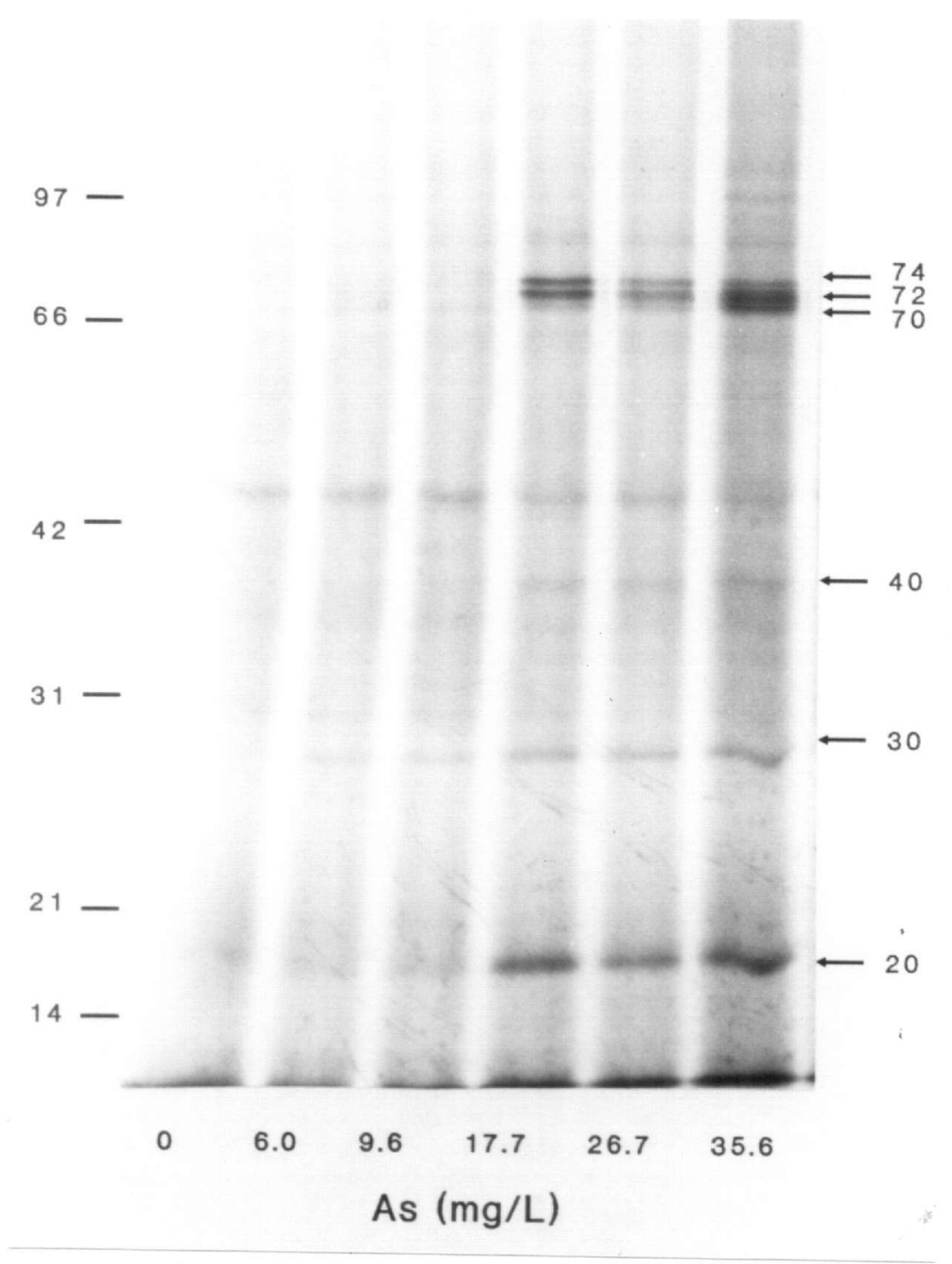

Figure 9A. A fluorogram of gill tissue proteins from fish exposed to 0, 6.0, 9.6, $17.7,26.7$, and $35.6 \mathrm{mg} \mathrm{As} / \mathrm{L}$ for $8 \mathrm{~h}$. Molecular weight markers are designated on the left. Arrows on the right denote stress proteins of 20,30, 40,70, 72, and 74 $\mathrm{kD}$. 


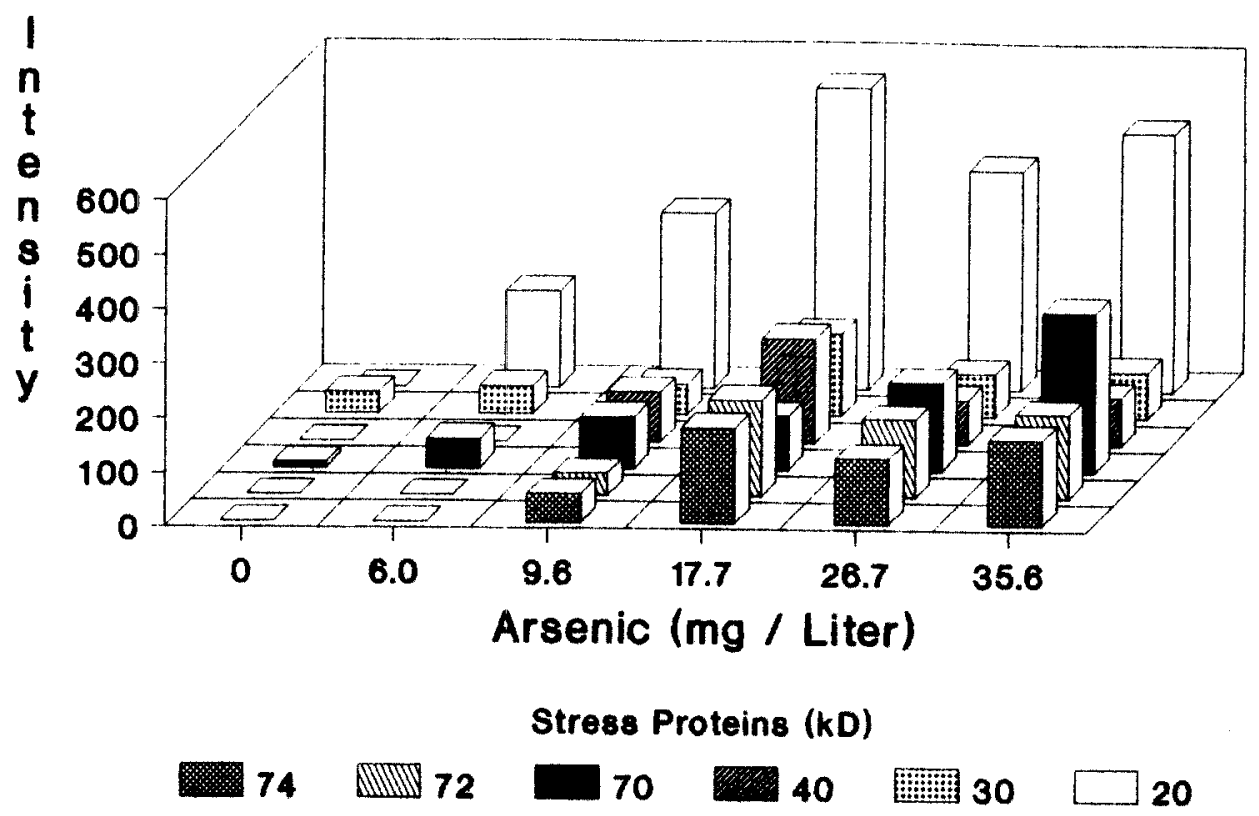

Figure 9B. Median intensities of $20,30,40,70,72$, and $74 \mathrm{kD}$ proteins in fluorograms from replicate samples $(n=5)$ of experiment described in $9 \mathrm{~A}$.

proteins observed (Figure 9B; Kruskal-Wallis, $\mathrm{p} \leq 0.05$ ). Arsenite treatments didnot significantly affect $\mathrm{p} 30$ synthesis and accumulation (Kruskal-Wallis, $\mathrm{p}=$ 0.16). Dunnett's $T$ test performed on ranked data showed significantly increased $(\mathrm{p} \leq 0.05)$ radiolabel incorporation above controls for proteins of 20,40 , and 70 $\mathrm{kD}$ from 9.6 to $35.6 \mathrm{mg} \mathrm{As} / \mathrm{L}$. Increased isotope incorporation into the $20 \mathrm{kD}$ protein was evident at $6.0 \mathrm{mg} \mathrm{As} / \mathrm{L}$ but was not significant due to high variance. For arsenite induced proteins 72 and 74 , significant increases occurred from 17.7 to $35.6 \mathrm{mg} \mathrm{As} / \mathrm{L}$. Overall, levels of incorportation were greatest into the $20 \mathrm{kD}$ protein, followed by proteins of $70,72,74,40$, and $30 \mathrm{kD}$, respectively. 


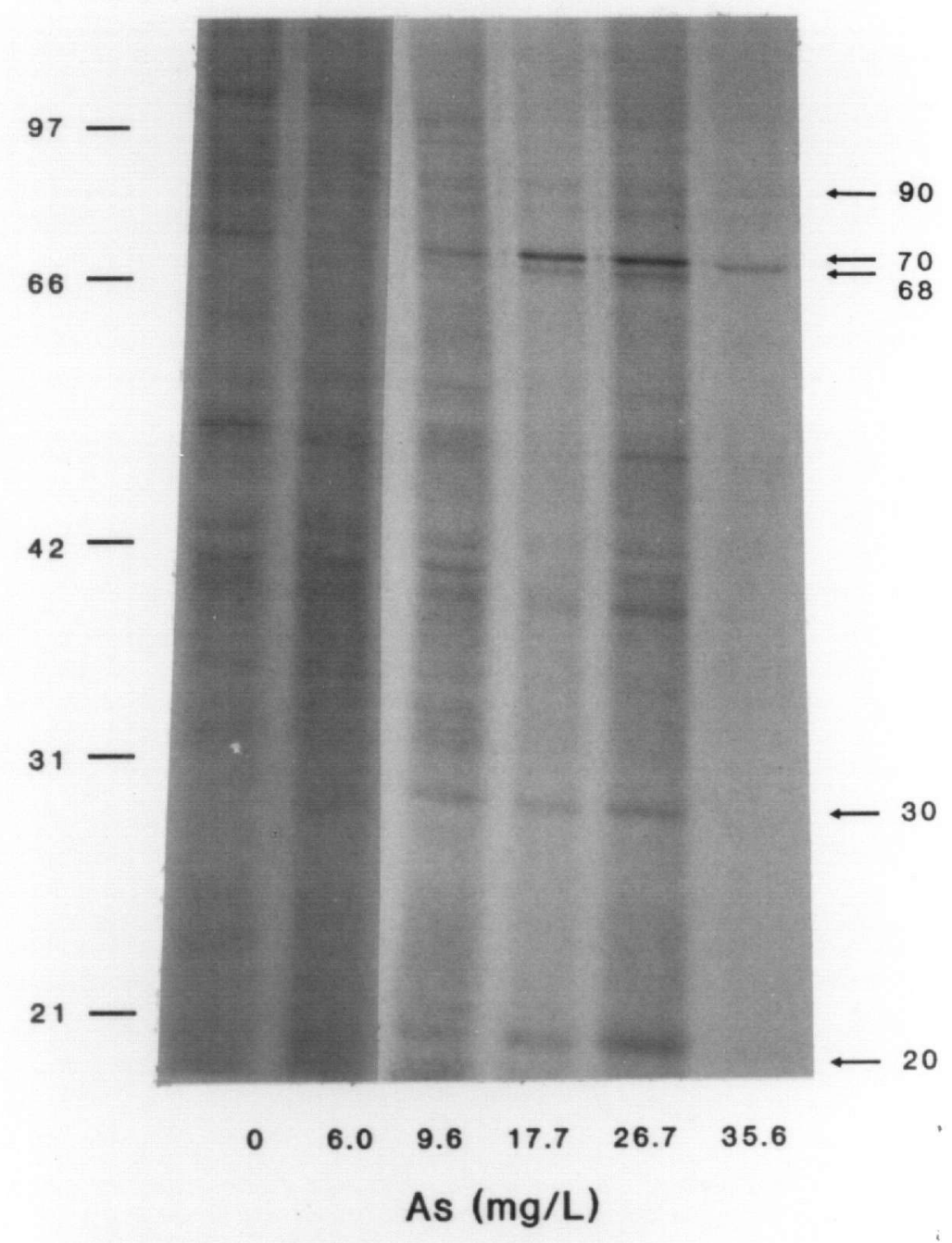

Figure 10A. A fluorogram of striated muscle tissue proteins from fish exposed to $0,6.0,9.6,17.7,26.7$, and $35.6 \mathrm{mg} \mathrm{As} / \mathrm{L}$ for $8 \mathrm{~h}$. Molecular weight markers are designated on the left. Arrows on the right denote stress proteins of 20,30,68, 70 , and $90 \mathrm{kD}$. 


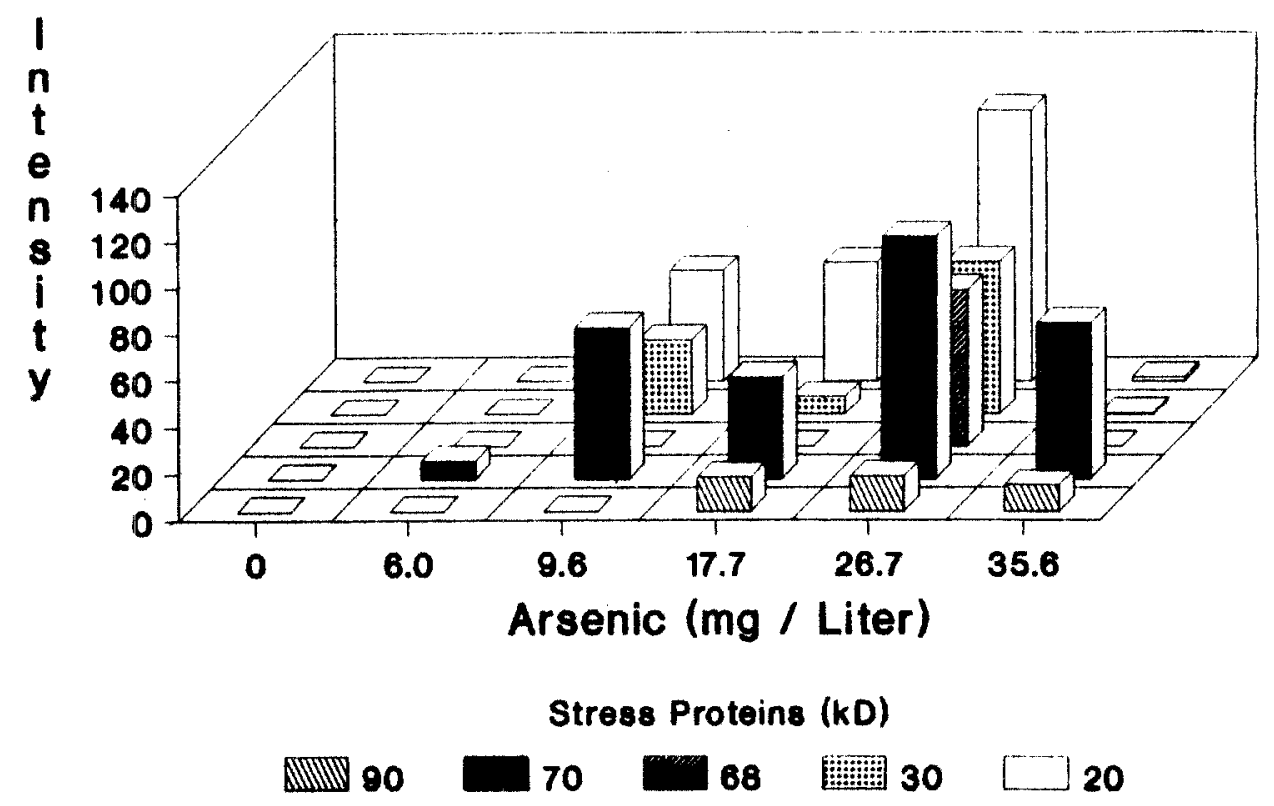

Figure 10B. Median intensities of $20,30,68,70$, and $90 \mathrm{kD}$ proteins in fluorograms from replicate samples $(n=5)$ of experiment described in $10 \mathrm{~A}$.

Five arsenite induced proteins of $20,30,68,70$, and $90 \mathrm{kD}$ were found in the striated muscle (Figure $10 \mathrm{~A}$ ). The $70-\mathrm{kD}$ protein was observed at all concentrations and showed increased incorporation rates above controls from 17.7 to $35.61 \mathrm{mg} \mathrm{As} / \mathrm{L}$. Increased incorporation of ${ }^{35} \mathrm{~S}$-methionine into proteins 20 and 30 occurred from 9.6 to $26.7 \mathrm{mg}$ As/L. There was no observable incorporation at the highest arsenite concentration for either protein. A $90-\mathrm{kD}$ protein was observed from 17.7 to $35.61 \mathrm{mg}$ As/L and the $68-\mathrm{kD}$ protein was seen from 17.7 to $26.7 \mathrm{mg} \mathrm{As} / \mathrm{L}$. Arsenite treatments significantly affected the synthesis and 
accumulation of all proteins quantitated in the striated muscle (Kruskal-Wallis, $p$ $\leq 0.05)$. In addition, Dunnett's $\mathrm{T}$ tests on ranked data showed significantly increased radiolabel incorporation into the $70-\mathrm{kD}$ protein above control levels from 17.7 to $35.61 \mathrm{mg} \mathrm{As} / \mathrm{L}$ (Figure 10B). Significantly increased incorporation levels were also observed with the $30-\mathrm{kD}$ protein at 9.6 and $26.7 \mathrm{mg} \mathrm{As} / \mathrm{L}$. The remaining of the proteins quantitated $(20,68$, and 90$)$ showed significant increases above controls at only $26.7 \mathrm{mg} \mathrm{As} / \mathrm{L}$.

Intensities from replicate fluorograms for each stress protein from both gill and striated muscle were correlated to $96-\mathrm{h}$ mortalities for each respective treatment replicate (Table 1). In the gill, synthesis and accumulation rates of stress induced proteins $20,70,72$, and 74 were significantly correlated with mortality. However, in striated muscle, only stress protein 70 was shown to be significantly correlated with mortality. The lack of radioisotope incorporation at the highest concentration compromised the correlation's significance.

Striated muscle protein from survivors of replicate number one was immunoblotted with antibodies to stress proteins 70 and 60 (Figure $11 \mathrm{~A}$ and 11B). Increased relative antibody binding for stress protein 70 occurred at all treatment concentrations compared to the control. In comparison, increased hsp $60 \mathrm{Ab}$ binding occurred at 9.6, 17.7, and $26.7 \mathrm{mg} \mathrm{As} / \mathrm{L}$. 
Table 1. Spearman rank correlations of stress protein intensities from gill and striated muscle tissues versus $96-\mathrm{h}$ mortality.

\begin{tabular}{llll}
\hline Tissue & $\begin{array}{l}\text { Stress } \\
\text { Protein }\end{array}$ & $\begin{array}{l}\text { Correlation } \\
\text { Coefficient }\end{array}$ & \\
& & & \\
& & & \\
Gill & 74 & 0.537 & 0.0056 \\
& 72 & 0.599 & 0.0020 \\
& 70 & 0.697 & 0.0001 \\
& 40 & 0.277 & 0.1807 \\
& 30 & 0.297 & 0.1499 \\
Striated Muscle & 20 & 0.626 & 0.0011 \\
& 90 & 0.240 & 0.2693 \\
& 70 & 0.417 & 0.0424 \\
& 68 & 0.201 & 0.3471 \\
& 30 & 0.064 & 0.7657 \\
& 20 & 0.192 & 0.3674 \\
& & & \\
\hline
\end{tabular}

Discussion

The acute exposure of fathead minnows to $25 \mathrm{mg} \mathrm{As} / \mathrm{L}$ resulted in the rapid and preferential synthesis of the stress induced proteins in gill tissue. By $2 \mathrm{~h}$, ${ }^{35} \mathrm{~S}$-methionine/cysteine incorporation rates into proteins with molecular weights of $20,30,40,70,72$, and $74 \mathrm{kD}$ were increased and continued throughout the $10-\mathrm{h}$ exposure period. The rapidity of this response to arsenite exposure has also been reported in HeLa, mouse fibroblast, and Neurospora crassa cells which have also been shown to elicite the stress response within 0.5 to $2 \mathrm{~h}$ (Duncan and Hershey, 1987; Kapoor and Lewis, 1987; Hiwasa and Sakiyama, 1986). 


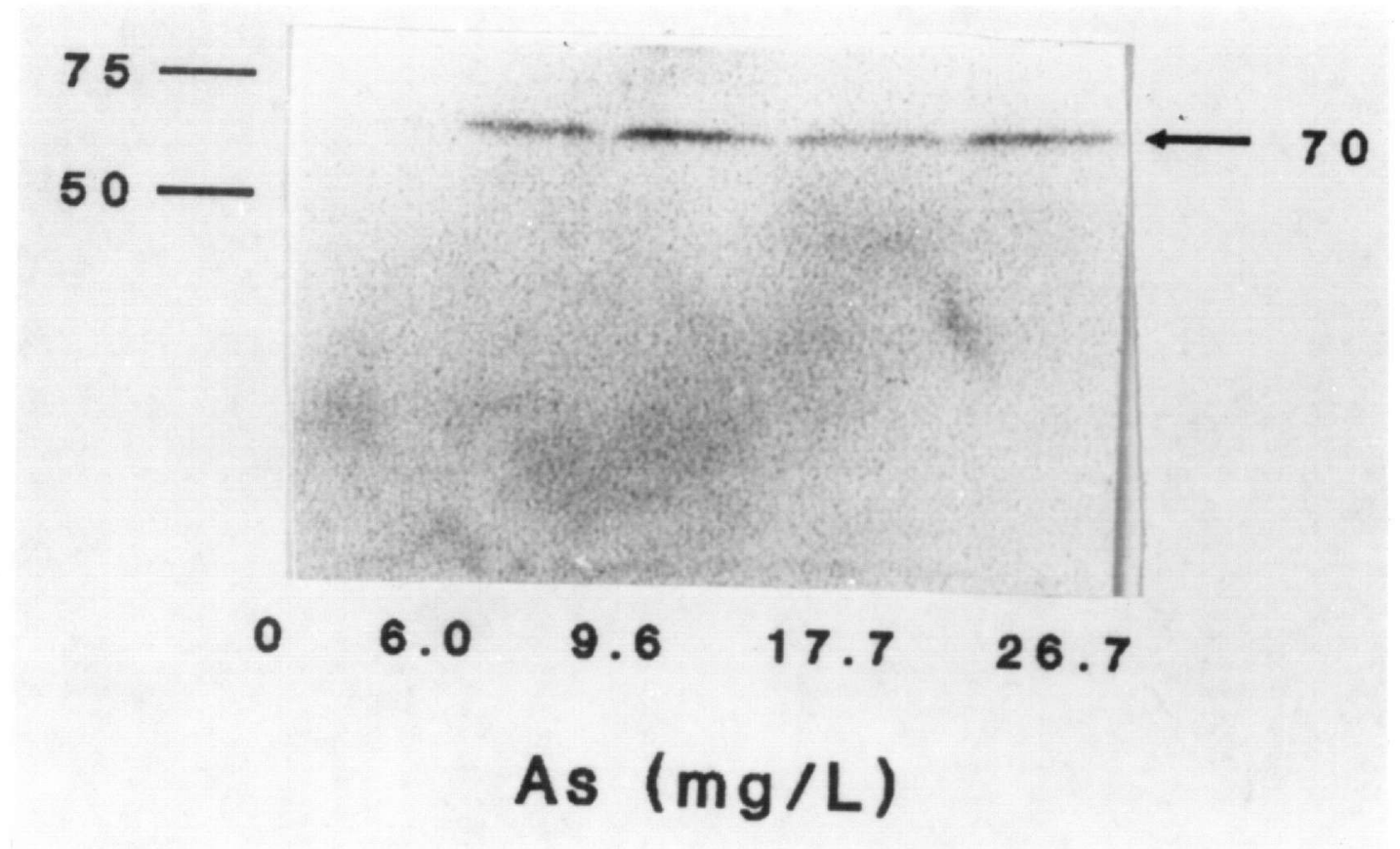

75

5

$\begin{array}{lllll}0 & 6.0 & 9.6 & 17.7 & 26.7\end{array}$

As $(\mathrm{mg} / \mathrm{L})$

Figure 11. A. Western blot of striated muscle tissue proteins, from fish that survived the $96 \mathrm{~h}$ toxicity test, against a monoclonal antibody raised against hsp70 (from Dr. W. Welch; Riabowol et al., 1988). Samples of equal protein were separated on a $12.5 \%$ polyacrylamide gel before blotting. Prestained molecular weight markers of 75 and $50 \mathrm{kD}$ are designated on the left. The arrow on the right denotes a single band with an apparent molecular weight of $70 \mathrm{kD}$.

B. Western blot of striated muscle tissue proteins, from fish surviving the $96 \mathrm{~h}$ toxicity test, against a monoclonal antibody raised against hsp60 (from Dr. S.

Miller; Miller 1987). Samples were run as described in A. Prestained molecular weight markers 75 and $50 \mathrm{kD}$ are designated on the left. The arrow on the right denotes a single band with an apparent molecular weight of $60 \mathrm{kD}$. 
Gill and striated muscle of fish exposed to different arsenite concentrations yielded different translational patterns. Gill synthesized more stress proteins (six) than muscle (five) and required a lower concentration of arsenite to induce the stress response. In addition, all proteins induced in the gill showed increased incorporation rates over all concentrations. However, the striated muscle showed little or no translation of stress proteins 20,30 , and 68 at the highest concentration possibly due to the overwhelming of transcriptional/translational processes. Two possible explanations exist that describe the pattern differences between these two tissues. First, is route of exposure. Of the two tissues examined, only the gill is directly exposed to arsenite, whereas the muscle required transport via the circulatory system. A second explanation may be that gill is more sensitive to changes in environmental conditions (i.e. temperature, $\mathrm{pH}$, conductivity, $\mathrm{DO}$, turbidity, etc.) compared to the muscle and, therefore, requires the inducement of protective mechanisms such as the stress protein response to cope with such changes. In support of this, a previous study in this laboratory showed that the temperature required to elicit the stress response in the gill was $3^{\circ} \mathrm{C}$ less than that for muscle (Dyer et al., in review).

Over all treatment levels the relative synthetic rates of the stress proteins were significantly correlated to percent mortality. In gill, significant concentrationresponses were determined for $20,40,70,72$, and $74 \mathrm{kD}$ proteins. Striated muscle showed significant concentration relationships with four proteins $(20,30,68,70$ $\mathrm{kD})$. Levels of radiolabel incorporation into proteins of $20,40,70,72$, and $74 \mathrm{kD}$ 
observed in the gill were significantly correlated with $96-\mathrm{h}$ percent mortality. In contrast, only one muscle protein, $70 \mathrm{kD}$, was significantly correlated to mortality. The lack of incorporation of isotope into stress proteins compromised correlations with the other five proteins $(20,30,40,68$, and $90 \mathrm{kD})$. Other investigations with in vitro arsenite exposures have also yielded similar results. Upon exposures of 1 to $100 \mathrm{uM}$ sodium arsenite, rainbow trout (Oncorhynchus mykiss) fibroblasts elicited increased synthetic rates of stress proteins $30,32,42,62,70,87$, and 100 with increased concentrations (Kothary and Candido, 1982). Similarly, synthesis of 40,70 , and $80 \mathrm{kD}$ proteins in Neurospora crassa cells also were found to be concentration dependent (Kapoor and Lewis, 1986).

In a previous study, translational patterns of gill and muscle of fathead minnows were determined via sublethal heat shocks. Gill was shown to elicit six stress proteins with molecular weights of $63,68,70,78,90$, and $100 \mathrm{kD}$. Striated muscle elicited four proteins of $70,78,90$, and $100 \mathrm{kD}$. This study, however, has shown elicitation of a different array of proteins in the same tissues. In gill, increased syntheses and accumulations of $20,30,40,72$, and $74 \mathrm{kD}$ proteins appeared to be specific for arsenite. Whereas, muscle showed arsenite specific elicitation of 20,30, and $68 \mathrm{kD}$ proteins. However, Merz and Laudien (1987) clearly showed that cultured fathead minnow epithelial cells exposed to heat stress elicit low molecular weight proteins of 22,36 , and $39 \mathrm{kD}$. Without performing comparative peptide analyses, such as has been conducted by Amaral et al. (1988), it is not known whether the proteins induced by heat shock, as shown by Merz 
and Laudien (1987), are the same as shown to be induced by arsenite in this study.

Immunoblots with hsp60 and 70 antibodies revealed that relative levels of stress proteins 60 and 70 in striated muscle of fish surviving the 96-h toxicity test were greater in treated fish. Increased stress protein antibody binding in treated samples, as compared to controls, is indicative of increased accumulation of stress proteins. Greater hsp $70 \mathrm{Ab}$ binding at $6.0 \mathrm{mg} \mathrm{As} / \mathrm{L}$ corresponded well with the MATC for fathead minnows, $3.33 \mathrm{mg}$ As/L (Spehar and Fiandt, 1986). Further, Sanders et al., (in press) has recently shown that accumulation of stress protein 60 in mantle tissue of Mytilus edulis is an order of magnitude more sensitive than scope for growth, a whole organism index of health. Thus, it appears that usage of immunological techniques to ascertain stress protein levels has potential as a highly sensitive method to determine chronic cellular and organismal stress.

Historically it has been reported that arsenite exerts its toxicity through interactions with sulfhydryl groups of enzymes. Binding to such groups often causes tertiary structural changes resulting in decreased catalytic activities. Inhibition of metabolic oxidative pathways, such as the TCA cycle, and glucose utilization result in a depletion of high energy substances in the cell (Webb, 1966).

Recent research has shown that structurally altered proteins serve as a signal for the stress response (Munro and Pelham, 1986; Ananthan, et al., 1986; Beckmann, et al., 1990). In addition, non-lysosomal degradation of denatured proteins is also inhibited by arsenite (Munro and Pelham, 1986; Klemperer and 
Pickart, 1989). The net result is that denatured proteins accumulate rapidly in the cell. The level of transcription or intensity of the response is relative to the level of signal (Mizzen and Welch, 1988).

This study showed that radiolabel incorporation into different stress proteins was tissue specific. However, both tissues elicited proteins of 20,30 , and $70 \mathrm{kD}$. Much is known about the functions of 70 and $30 \mathrm{kD}$ stress proteins in cellular metabolism but relatively little is known about $20 \mathrm{kD}$ proteins. Stress protein 70 has been shown to have at least three functions, multimeric protein assembly, unfolding for translocation, and disaggregation of protein aggregates (Craig, 1989; Rothman, 1989; Welch, 1990; Schlesinger, 1990). These functions are thought to facilitate repair of proteins and protein complexes associated with common and critical metabolic processes, therefore protecting cells from stressor induced damage.

Recently, a $32 \mathrm{kD}$ stress protein known to be induced by arsenite, heavy metals, and oxidizing agents has been identified to be heme oxygenase (Shibahara et al., 1987; Keyse and Tyrell, 1989). This is an essential enzyme in heme catabolism where it cleaves heme to form biliverdin. Biliverdin is subsequently converted to bilirubin via biliverdin reductase. These heme products have been shown to be efficient peroxyl radical scavengers (Stocker et al., 1987a; Stocker et al., 1987b). Thus, it has been suggested that induction of heme oxygenase may be part of a protective response against oxidative damage (Keyse and Tyrell, 1989). 
Little is known about the function of the remaining stress protein, 20. However, several proteins in the $20-27 \mathrm{kD}$ range have been investigated in a variety of cell cultures. This family of stess proteins are known to be phosphorylated during cell stress (Kim et al., 1984; Duncan and Hershey, 1987; Regazzi et al., 1988). These phosphorylated proteins accumulate in the nucleus and other large sedimenting organelles where it is suggested that they perform their protective processes (Kim et al., 1984; Duband et al., 1986; Arrigo, 1987).

These data support previous suggestions (Sanders et al., 1990; Sanders, 1990) that the stress protein response should be considered as a potential biomonitoring tool. Increased translation of stress proteins due to arsenite exposure and their significant correlation to percent mortality further suggest that the stress protein response may function as a biochemical indicator of both exposure and effects. 
Chromate Exposures

Materials and methods

Ninety-day-old fathead minnows (Pimephales promelas) were obtained from a culture located at the University of North Texas. Fish used for the study were acclimated to $25^{\circ} \mathrm{C}$ for at least 7 days and a $16 \mathrm{~L}: 8 \mathrm{D}$ photoperiod and were fed frozen brine shrimp twice daily to satiation.

An initial range-finding experiment was carried out to determine a range of sodium chromate concentrations suitable for a definitive LC50 test and to determine times to first signs of intoxication. Aquaria (19L) were filled to $10 \mathrm{~L}$ with nominal concentrations of $0,10,50,100,150$, and $200 \mathrm{mg} \mathrm{Cr} / \mathrm{L}$. Each treatment was replicated twice. Fish (7 to 12) were placed into each treatment replicate and observed for onset of intoxication. Fish in $100 \mathrm{mg} \mathrm{Cr} / \mathrm{L}$ tanks, showed first signs of intoxication by $6-12 \mathrm{~h}$, with nearly $30 \%$ dead in $24 \mathrm{~h}$. Fish in other treatments showed signs of intoxication later than $12 \mathrm{~h}$, or the treatments were too toxic, with mortalities occurring within $8 \mathrm{~h}$. Thus, $100 \mathrm{mg} \mathrm{Cr} / \mathrm{L}$ was used as the exposure concentration for the time to stress protein induction study.

In order to determine the length of time required for stress protein induction, fish were exposed to $100 \mathrm{mg} \mathrm{Cr} / \mathrm{L}$ and sampled at $0,2,4,6,8,10$ and 12h. Two replicates of three fish each were sampled at each time interval. Immediately after sampling, fish were sacrificed and gill tissue (mean wet weight \pm standard deviation $=51.1 \pm 7.2 \mathrm{mg}$ ) was dissected and pooled within each treatment replicate. Tissues were metabolically labeled for $2 \mathrm{~h}$ with ${ }^{35} \mathrm{~S}$ - 
methionine and cysteine. Incorporation of label into proteins was examined by SDS-PAGE and fluorography. Resulting fluorograms showed that all stress proteins observed within the $12-\mathrm{h}$ treatment period were maximally induced at 12h. Thus, $12 \mathrm{~h}$ was selected as the appropriate sampling time to examine the stress protein response in the subsequent definitive 96-h toxicity test.

To assess the concentration range in which gill and striated muscle tissues synthesize stress proteins, fish were exposed to five different chromate concentrations $(9.0 \pm 1.3 ; 49.7 \pm 2.7 ; 75.4 \pm 2.4 ; 104.9 \pm 1.6 ; 159.4 \pm 2.5 \mathrm{mg}$ $\mathrm{Cr} / \mathrm{L}$ ), plus control, and sampled at $12 \mathrm{~h}$. Each treatment was replicated five times. Thirteen fish were placed into each treatment replicate and three were subsampled at $12 \mathrm{~h}$ while the rest were exposed for $96 \mathrm{~h}$. Tissues of subsampled fish (gill $46.7 \pm 7.2$; striated muscle $46.7 \pm 6.5 \mathrm{mg}$ ) destined for metabolic labeling were treated as in the induction study. Time to mortality was recorded every $24 \mathrm{~h}$. Metabolic labeling, sample preparation, SDS-PAGE, and densitometric quantitation of fluorograms was conducted as described in the arsenite experiment's materials and methods section. However, X-ray films used for quantitation were exposed to radiolabeled gels for $5 \mathrm{~d}$. Survivors of the 96-h toxicity test were sacrificed and immediately placed into a $-80^{\circ} \mathrm{C}$ freezer and later assayed for stress protein 70 levels using quantitative immunoblots.

Gill and striated muscle proteins from $96-\mathrm{h}$ toxicity test survivors were digested and serially diluted in sample buffer. Dilutions were loaded into seven wells of a $12.5 \%$ SDS-polyacrylamide gel and subsequently electrophoresed. 
Proteins in gels were then transferred to nitrocellulose using a transfer buffer containing $1 \%$ SDS, $0.192 \mathrm{M}$ glycine in $0.025 \mathrm{M}$ tris and $20 \%$ methanol $(\mathrm{v} / \mathrm{v}), \mathrm{pH}$ 8.3. The gels were subjected to $25 \mathrm{~V}$ for $15 \mathrm{~h}$ at $4^{\circ} \mathrm{C}$. The nitrocellulose was then blocked for $1 \mathrm{~h}$ in tris buffered saline (TBS) which contained $3 \%$ gelatin.

The nitrocellulose was probed using a monoclonal antibody $(\mathrm{Ab})$ raised against hsp72/73 from HeLa cells (generously provided by W. Welch; Riabowol, et al., 1988). Blots were incubated at room temperature with hsp $72 / 73 \mathrm{Ab}$ for $2 \mathrm{~h}$ and subsequently rinsed several times with TBS containing $0.5 \%$ Tween-20 (TTBS). The blots were then incubated with a second antibody of goat antimouse alkaline phosphatase (AP) conjugated antibody (BIORAD) for $2 \mathrm{~h}$. The blots were washed several times with TTBS and TBS and incubated with the substrates 5-bromo 4-chloro 3-indoyl phosphate p-toluidine salt and p-nitro blue tetrazolium chloride (BIORAD) to visualize bound antibody. The least amount of total protein required to visualize stress protein bands was recorded as the minimum detection level, which was verified using a laser densitometer.

All exposures used dechlorinated tap water that had the following characteristics: alkalinity $100 \mathrm{mg} \mathrm{CaCO} / 3$; hardness $120 \mathrm{mg} \mathrm{CaCO} / \mathrm{L}$; and conductivity 300 umhos. Dissolved oxygen and $\mathrm{pH}$ were monitored for each test. Mean dissolved oxygen was $6.5 \pm 0.7 \mathrm{mg} \mathrm{O} / \mathrm{L}$ while $\mathrm{pH}$ was $7.7 \pm 0.3$ over all concentrations. Chromium concentrations were determined using a Perkin Elmer atomic absorption spectrophotometer (EPA Method 218.1). 
Concentration effects on mortality were determined by parametric analysis of variance on arcsine transformed percent mortality data. Comparisons to controls were made by one-tailed Dunnett T tests. The LC50 and LC1 were determined by probit analysis. Stress protein intensities were analyzed nonparametrically due to heteroscedacity. Kruskal-Wallis analysis of variance on ranked intensity data was used to determine the significance of treatment effects (alpha $=0.05)$ on specific stress protein intensities. Comparisons to controls were determined by one-tailed Dunnett $\mathrm{T}$ tests on ranked data. Spearman rank correlations were used to compare percent mortality to stress protein intensities. Data are presented in three-dimensional plots in order to fully illustrate intensity data for each of the stress proteins versus arsenic concentration. Due to the high variability of ${ }^{35} \mathrm{~S}$-methionine/cysteine incorporation into some stress proteins, increased bar height above that of the controls should not be interpreted as being necessarily statistically significant. Data from the quantitative immunoblots were analyzed by parametric analysis of variance and one-tailed Dunnett's $T$ test on raw data.

Results

Chromate treatments caused significant changes in mortality (parametric AOV, $\mathrm{p}=0.0001)$. Percent mortality was $2.0 \%$ and $1.3 \%$ in controls and $9.9 \mathrm{mg}$ $\mathrm{Cr} / \mathrm{L}$. Average mortalities in the other concentrations (49.7, 75.4, 104.9, and 159.4 $\mathrm{mg} \mathrm{Cr} / \mathrm{L}$ ) were $35.8,67.2,86.4$, and $94.7 \%$, respectively. A Dunnett's $\mathrm{T}$ test 


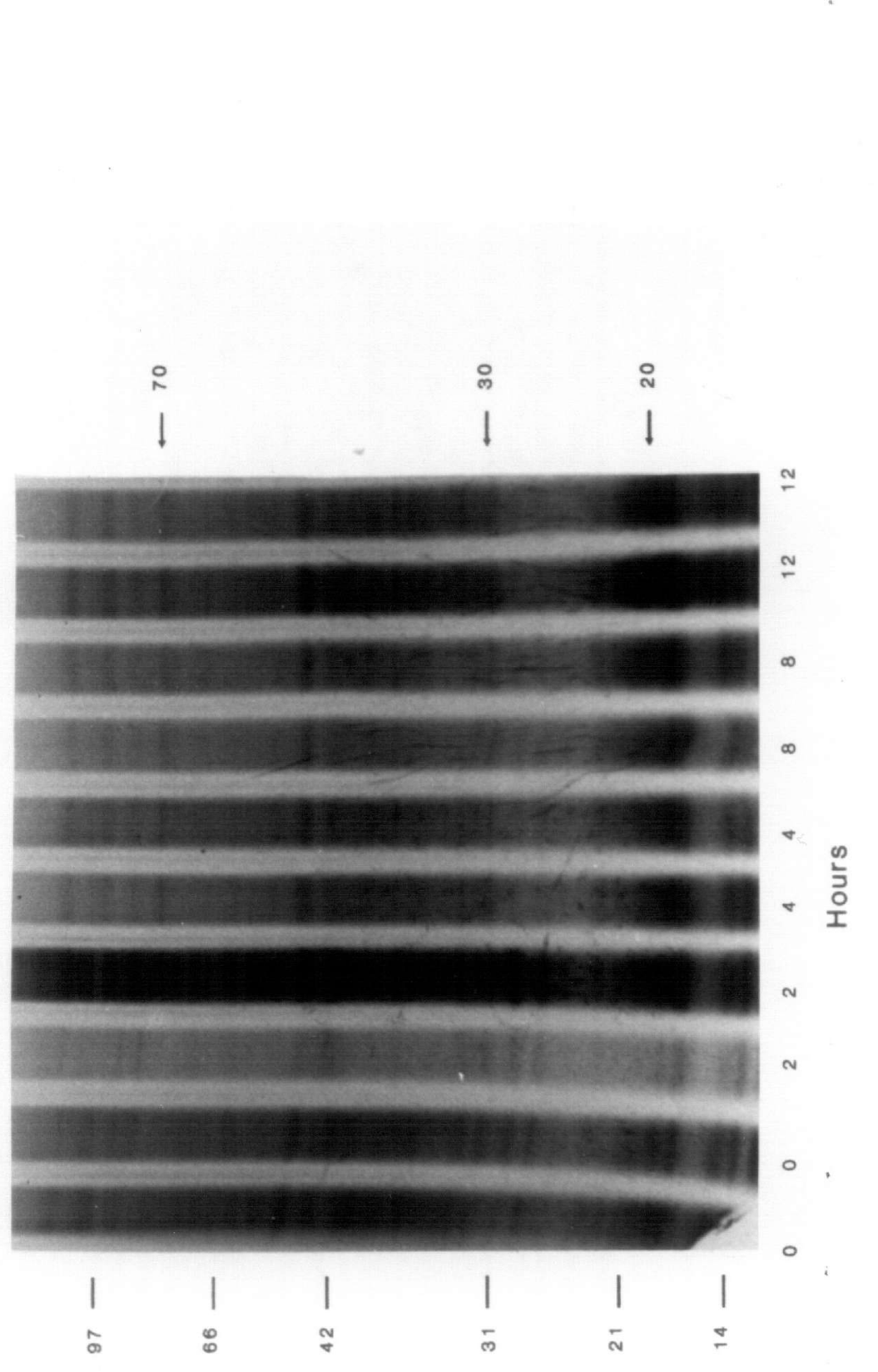

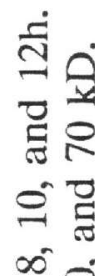

$0^{\infty}$ ह

+ิ

ते

○ิ

는

สิํㅡ

葛管

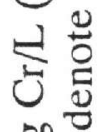

品

马.

온

모

这娄

育

넝

告

苋

宫

纪

司岕

茨。

봅

ప్

을 흠

$\ll \bar{\jmath}$

그 츠

ข

岕 
revealed that significantly increased mortality, compared to controls, occurred at $49.7 \mathrm{mg} \mathrm{Cr} / \mathrm{L}$ to $159.4 \mathrm{mg} \mathrm{Cr} / \mathrm{L}(\mathrm{p} \leq 0.05)$. Probit analysis determined the $\mathrm{LC} 50$ to $60.1 \mathrm{mg} \mathrm{Cr} / \mathrm{L}$ and the $\mathrm{LC} 1$ to be $18.1 \mathrm{mg} \mathrm{Cr} / \mathrm{L}$.

The stress protein response was elicited in gill tissue of fathead minnows exposed to $75 \mathrm{mg} \mathrm{Cr} / \mathrm{L}$. Three different stress proteins with apparent molecular weights of 20,30 , and $70 \mathrm{kD}$ were observed (Figure 12). Incorporation of ${ }^{35} \mathrm{~S}$ methionine/cysteine into each of the stress proteins increased with time of exposure. Densitometric analysis indicated that maximum incorporation of radiolabel into all three proteins occurred at $12 \mathrm{~h}$ exposure. Thus, a 12-h exposure was deemed to be an appropriate sampling time for the concentration response study. Our goal was to correlate incorporation of radiolabel into stress proteins to an eventual effect, namely percent mortality.

A qualitative description of one of the replicate fluorograms with gill tissue shows that radiolabel incorporation into proteins of 20,30 , and $70 \mathrm{kD}$ did not increase with increased chromate concentration (Figure 13A). However, statistical analysis of densitometric scans over all treatments showed that chromate concentration significantly affected isotope incorporation into only the $70 \mathrm{kD}$ protein (Figure 13B; Kruskal-Wallis, $\mathrm{p}=0.04$ ). A Dunnett's $\mathrm{T}$ test performed on ranked data showed significantly increased radiolabel incorporation into $\mathrm{sp} 70$ above control rates at $75.4 \mathrm{mg} \mathrm{Cr} / \mathrm{L}$. As found in gill, three proteins of 20,30 , and $70 \mathrm{kD}$ were observed in striated muscle (Figure 14A). Increased incorporation of ${ }^{35} \mathrm{~S}$-methionine/cysteine into the $30 \mathrm{kD}$ protein occurred from 49.7 to $104.9 \mathrm{mg}$ 
$\mathrm{Cr} / \mathrm{L}$. The incorporation of radiolabel into p20 was greater than controls at chromate concentrations of 104.9 and $159.4 \mathrm{mg} \mathrm{Cr} / \mathrm{L}$. No discernable differences over all chromate treatments were observed for the $70 \mathrm{kD}$ protein.

Taking all replicates into account, chromate treatments significantly affected the synthesis and accumulation of only the $20 \mathrm{kD}$ protein in the striated muscle (Figure 14B; Kruskal-Wallis, $\mathrm{p}=0.04$ ). Significantly increased radiolabel incorporation occurred at 49.7, 75.4, and $159.4 \mathrm{mg} \mathrm{Cr} / \mathrm{L}$ (Dunnett's $\mathrm{T}$ test, $\mathrm{p} \leq 0.05$.). Significance of treatment levels on stress protein 30 synthesis and accumulation was compromised due to high variance.

Intensities from replicate fluorograms from both gill and striated muscle were correlated to 96-h mortalities for each respective treatment replicate. In gill, incorporation of radiolabel into $70 \mathrm{kD}$ protein was highly significantly correlated with mortality (Spearman correlation, $r=0.54, p=0.0026$ ). The other two proteins $(20$ and $30 \mathrm{kD}$ ) were not significantly correlated with mortality. The $20 \mathrm{kD}$ protein found in striated muscle was highly significantly correlated with mortality $(\mathrm{r}=0.50, \mathrm{p}=0.0086)$. In contrast, proteins of 30 and $70 \mathrm{kD}$ were not found to be correlated with mortality.

Gill and striated muscle protein of 96-h survivors were immunoblotted with an antibody to hsp 72/73 (Figure 15). Two bands with apparent molecular weights of 70 and $68 \mathrm{kD}$ were observed in gill whereas only one band, $70 \mathrm{kD}$, was found in the striated muscle. The number of micrograms of total protein required for minimum detection decreased markedly with increased chromate concentration for 


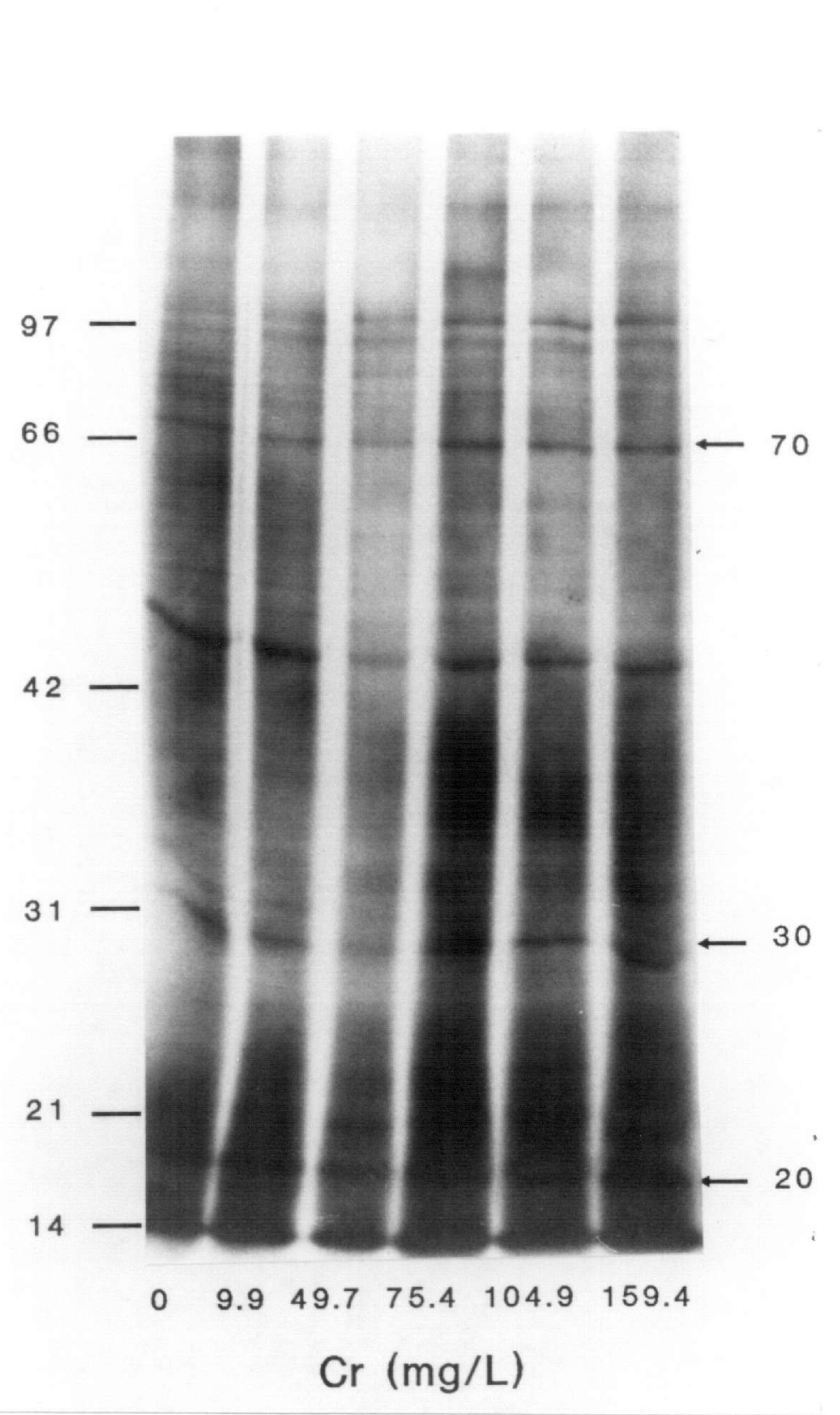

Figure 13A. A fluorogram of gill tissue proteins from fish exposed to 0, 9.9, 49.7, 75.4, 104.9, and $159.4 \mathrm{mg} \mathrm{Cr} / \mathrm{L}$ for $12 \mathrm{~h}$. Molecular weight markers are designated on the left. Arrows on the right denote stress proteins of 20,30 , and $70 \mathrm{kD}$. 


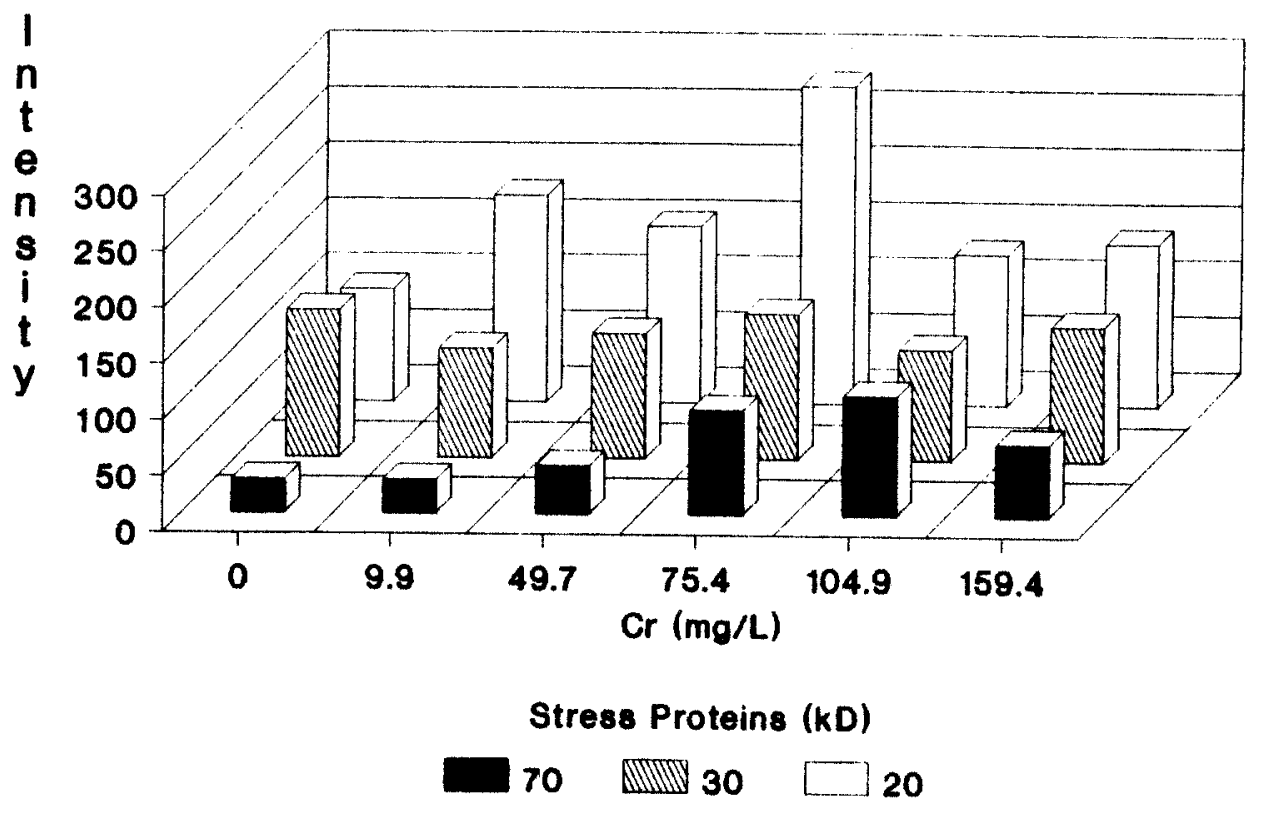

Figure 13B. Median intensities of 20,30 , and $70 \mathrm{kD}$ proteins in fluorograms from replicate samples $(n=5)$ of experiment described in $13 \mathrm{~A}$.

the $68-\mathrm{kD}$ band in the gill. In comparison, detection levels for the $70-\mathrm{kD}$ bands of both gill and muscle tissues were only slightly lower in treated fish versus control fish. Parametric analysis of variance showed that chromate concentrations had no significant effect on the $70 \mathrm{kD}$ band protein levels in both gill and muscle. Contrastingly, the $68-\mathrm{kD}$ band of the gill was highly significantly affected by treatment levels (ANOVA, $\mathrm{p}=0.0001$ ). Dunnett's $\mathrm{T}$ test performed on raw data showed that minimum detection levels for the $68-\mathrm{kD}$ protein from treated fish were significantly less than those from controls $(p \leq 0.05)$. Levels of the $68-\mathrm{kD}$ 


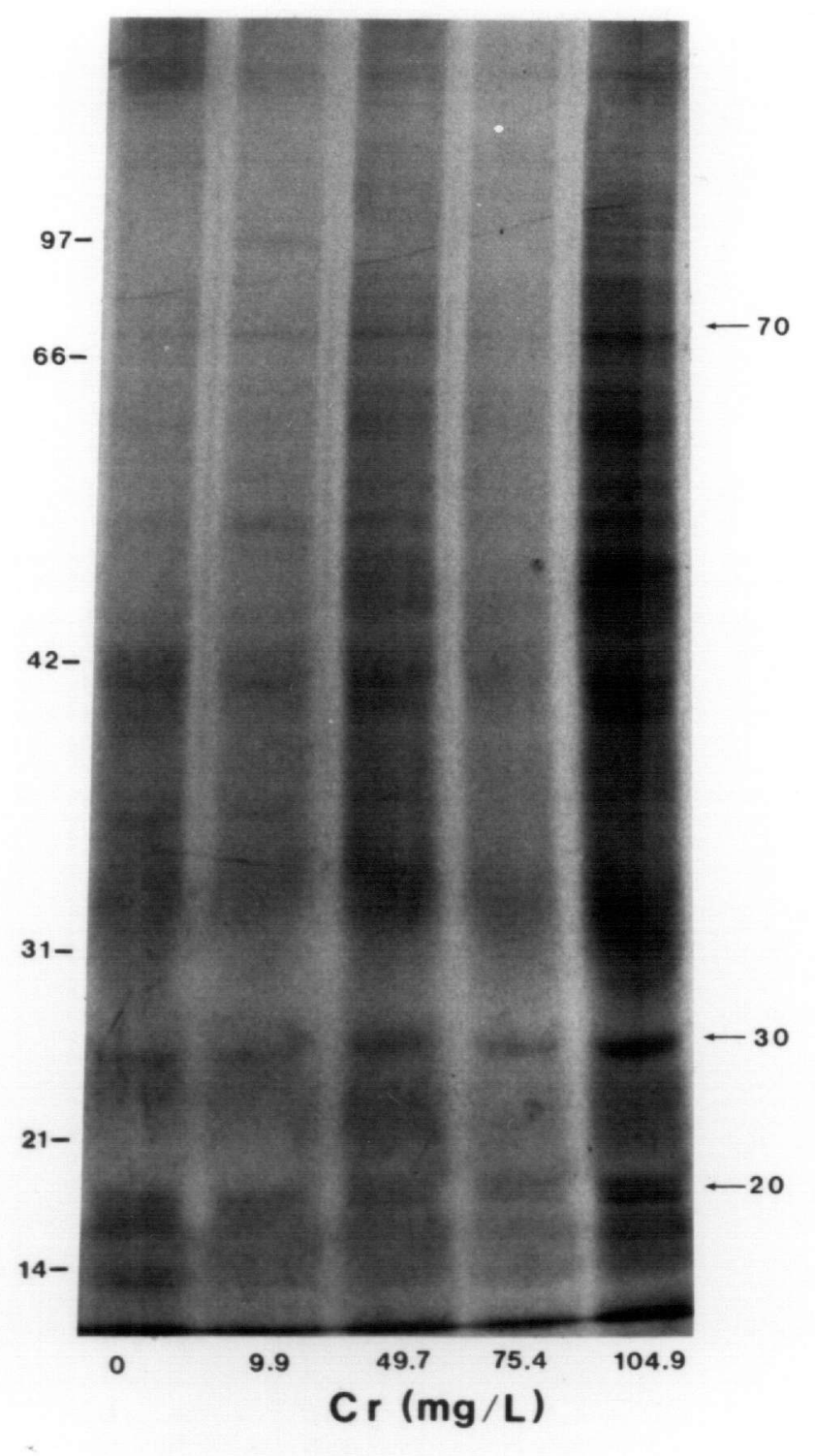

Figure 14A. A fluorogram of striated muscle tissue proteins from fish exposed to $0,9.9,49.7,75.4,104.9$, and $159.4 \mathrm{mg} \mathrm{Cr} / \mathrm{L}$ for $12 \mathrm{~h}$. Molecular weight markers are designated on the left. Arrows on the right denote stress proteins of 20,30, and $70 \mathrm{kD}$. 


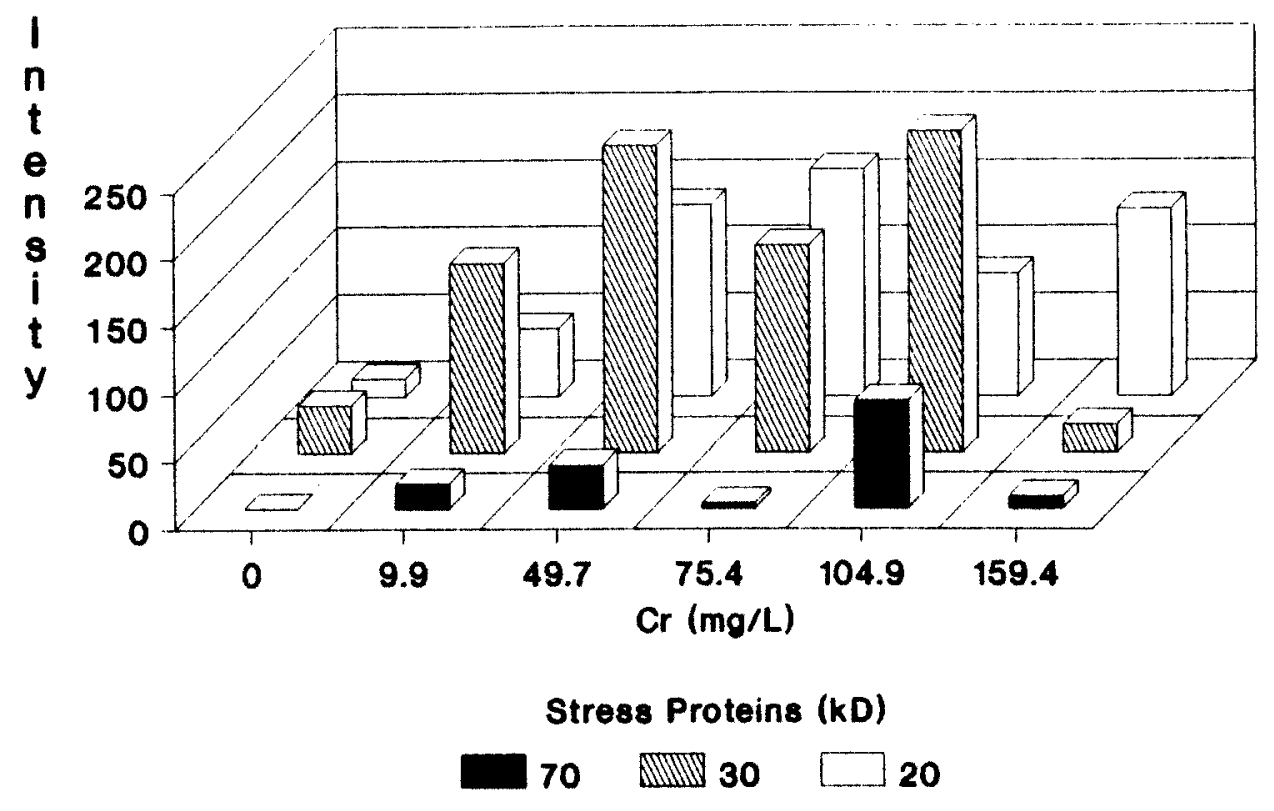

Figure 14B. Median intensities of 20,30 , and $70 \mathrm{kD}$ proteins in fluorograms from replicate striated muscle samples $(n=5)$ of experiment described in $13 \mathrm{~A}$.

protein were highly significantly correlated to percent mortality (Spearman rank correlation, $\mathrm{p}=0.0002, \mathrm{r}=-0.74)$.

Discussion

The translation pattern in gill of fathead minnows was found to be affected upon acute exposure to $75 \mathrm{mg} \mathrm{Cr} / \mathrm{L}$. By $12 \mathrm{~h}$, synthesis and accumulation of proteins with molecular weights of 20,30 , and $70 \mathrm{kD}$ had increased beyond $0-\mathrm{h}$ levels. Similarly, synthesis of the stress proteins in mouse fibroblasts has been shown to be induced by $0.2 \mathrm{mM} \mathrm{K}_{2} \mathrm{CrO}_{4}$ within $2 \mathrm{~h}$ (Hiwasa and Sakiyama, 1986). 


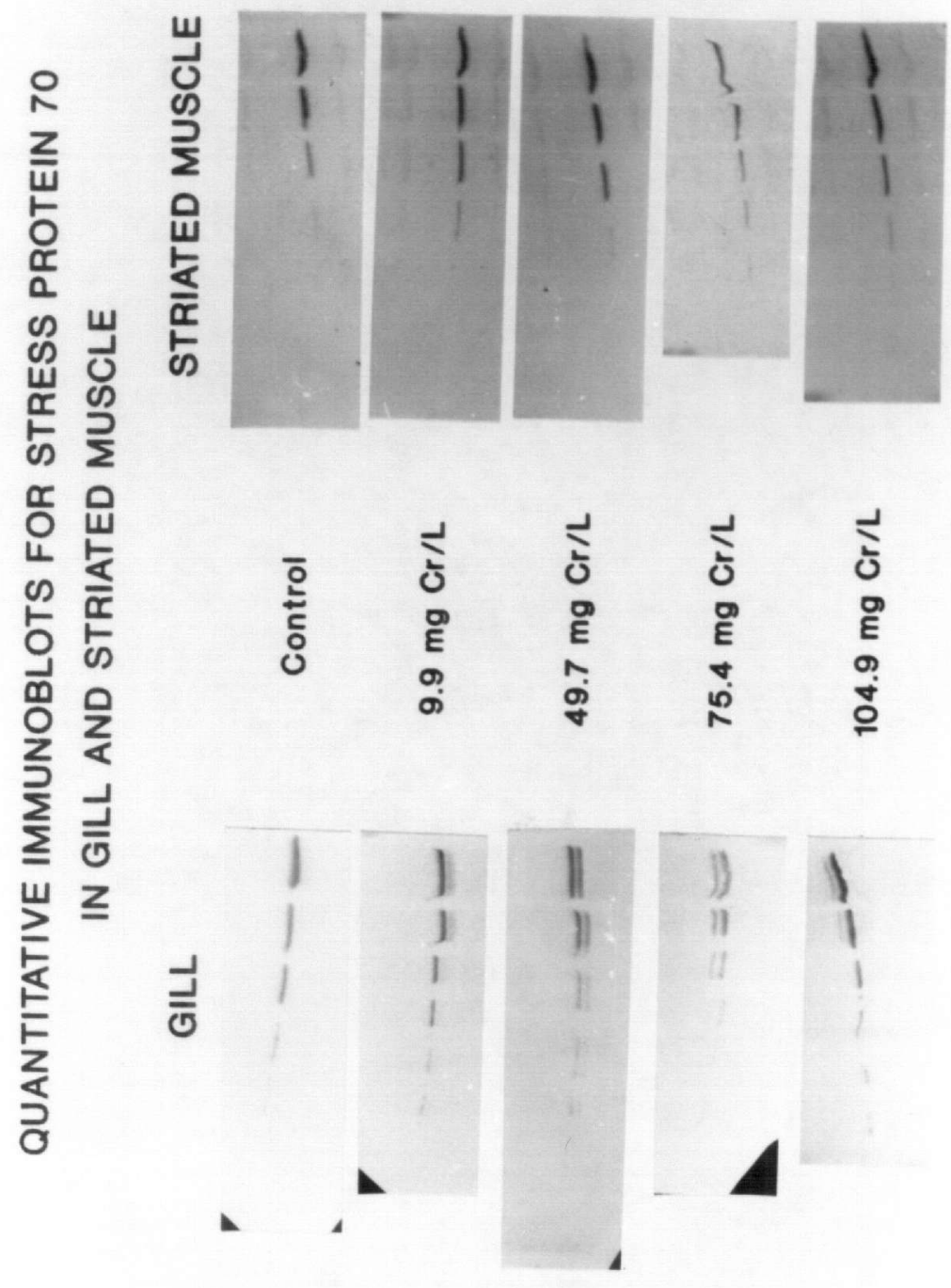

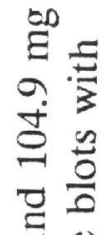

สำ

n

ก苾

จे

a

จำ

○

로

ญे पे

放

递

फ

$\cong$

会

을

छ

밈

患

릉

흥.

पे

$\approx$

응 恣

肎芯

.

등

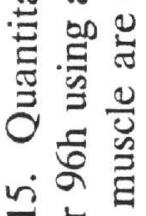

는 응

骂导恶 


\section{Stress Protein 68 Levels and Percent Mortality vs. Chromium Concentration}

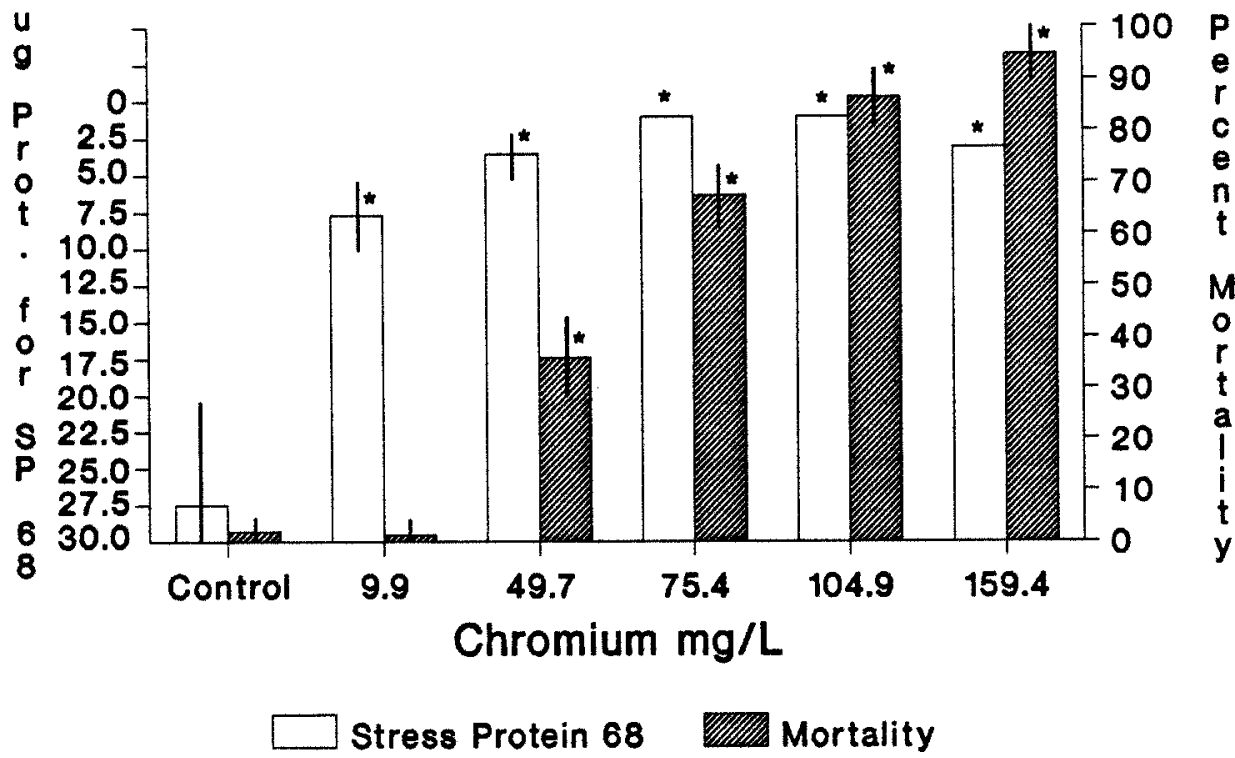

Figure 16. The relationships between accumulation of the $68-\mathrm{kD}$ protein, as determined via quantitative immunoblots, and percent mortality of fish exposed to different chromium concentrations for $96 \mathrm{~h}$. Open bars correspond to mean number of micrograms of total protein required for minimum stress protein detection \pm standard deviation. Hatched bars correspond to mean percent mortality \pm SD. Asterix denote significance from controls, as determined by Dunnett's T tests.

Gill and striated muscle from fish exposed to a range of chromium concentrations yielded similar translational patterns. Both tissues elicited three stress induced proteins of 20,30 and $70 \mathrm{kD}$. Significant concentration response relationships were determined for synthesis and accumulation of the $70 \mathrm{kD}$ protein in gill and the $20 \mathrm{kD}$ protein in the striated muscle. Incorporation of radiolabel into both 
proteins, as mentioned, were also significantly correlated with percent mortality. Significant concentration-response relationships for the $20 \mathrm{kD}$ protein of the gill and the $30 \mathrm{kD}$ protein found in the muscle were not observed due to high variance within the controls.

Gill and striated muscle protein from 96-h survivors were quantitatively immunoblotted with a monoclonal hsp $72 / 73 \mathrm{Ab}$. Both tissues synthesized a $70-\mathrm{kD}$ protein whose levels did not change significantly with $\mathrm{Cr}$ concentration. However, the gill also synthesized a $68 \mathrm{kD}$ protein whose levels accumulated and were significantly correlated to $\mathrm{Cr}$ concentration and percent mortality. A comparison between accumulation of the $68-\mathrm{kD}$ protein and percent mortality values showed that significantly increased accumulations of the $68 \mathrm{kD}$ protein occurred at concentrations of $9.9 \mathrm{mg} \mathrm{Cr} / \mathrm{L}$ and greater whereas significant increases in mortality occurred at $49.7 \mathrm{mg} \mathrm{Cr} / \mathrm{L}$ and greater. Thus, accumulation of the $68-\mathrm{kD}$ protein was five-fold more sensitive than 96-h mortality.

Potential use of immunoblot technology to ascertain chronic toxicant exposure appears to have great potential. For example, significantly increased 68$\mathrm{kD}$ protein accumulation occurred at a concentration nearly half that of the LC1, $18.1 \mathrm{mg} \mathrm{Cr} / \mathrm{L}$. In addition, significant accumulations at $9.9 \mathrm{mg} \mathrm{Cr} / \mathrm{L}$ correspond well with the MATC for fathead minnows, $2.3 \mathrm{mg} \mathrm{Cr} / \mathrm{L}$ (Spehar and Fiandt, 1986). Furthermore, Sanders et al., (in press) has recently shown accumulation of sp60 in mantle tissue of Mytilus edulis to be an order of magnitude more sensitive than scope for growth, a sublethal whole organism index of health. In contrast, 
significantly increased radiolabel incorporation into stress proteins 70 (gill) and 20 (striated muscle) was first determined at concentrations in which acute mortality resulted. This comparison illustrates the marked difference in the sensitivity of the two methods employed to examine the stress protein response, that of radiolabel incorporation into proteins (less sensitive) vs. stress protein accumulation as determined by quantitative western blots (more sensitive).

Toxicity of chromium is dependent on chemical speciation and subsequent associated health effects are, thus, influenced by the chemical form of the exposure (Nieboer and Jusys, 1988). In general, chromium toxicity has been attributed to two species; CrVI, such as sodium chromate, and CrIII (Holdway, 1988). In biologic systems, CrVI has been found to oxidize low-molecular-weight reductants (i.e. cysteine, glutathione, lipoic acid), proteins, and DNA (Ono, 1988; Nieboer and Jusys, 1988; Nieboer and Shaw, 1988). At physiologic pH's, CrVI is rapidly reduced to CrIII (Nieboer and Jusys, 1988). This species (CrIII) has been shown to exhibit a high affinity for nucleotides and nucleic acids (NAS, 1974, Nieboer and Jusys, 1988). The binding of CrIII to nucleic acids and nucleotides, results in the displacement of MgII as the major counterion. This ion swap alters the three-dimensional geometry of RNA and DNA. Thus it is not surprising that DNA replication and protein translation become impaired and result in mutagenesis and carcinogenesis (Ono, 1988; Nieboer and Shaw, 1988; Yassi and Nieboer, 1988) as well as the potential production of aberrant proteins.

Chromium VI exerts its toxicity in fish in a manner different from most 
heavy metals. Whereas cationic metals such as $\mathrm{Zn}$ and $\mathrm{Cd}$ have been shown to accumulate in the gill and drastically alter lamellar structure and function (Skidmore and Tovell, 1972; Olsson and Hogsatrand, 1987), CrVI exists as an oxoanion which allows it to pass readily through gill membranes and accumulate within internal organs (Van der Putt et al., 1981; Van der Putt and Part, 1982). It has been postulated that at exposure pH's of 7.8 and greater that CrVI induced toxicity is caused by pathological changes within internal organs (Van Der Putt et al, 1981). This has also been supported by the lack of response from various enzymes in gill versus those in other tissues ( Kuhnert et al., 1976; Buhler et al, 1977). Even so, chromium has repeatedly been shown to accumulate rapidly in gill and localize in microsomal and soluble fractions (Kuhnert et al, 1976; Buhler et al, 1977; Van der Putt et al, 1981).

Causal factors that relate chromium exposure and induction of the stress proteins have thus far been ignored. Our study showed that in both gill and muscle tissues three stress proteins were synthesized, 20-, 30- and 70-kD. In regard to function, much is known of the $70-$ and $30-\mathrm{kD}$ stress proteins in cellular metabolism, but not as much is known about the $20-\mathrm{kD}$ protein. Stress protein 70 has been shown to have at least three functions, multimeric protein assembly, unfolding, for translocation, and disaggregation of protein aggregated (Craig, 1989; Rothman, 1989; Welch, 1990; Schlesinger, 1990). These functions are thought to facilitate repair of proteins and proteins complexes associated with common and critical metabolic processes and thus protect cells from stressor induced damage. 
Recent research has shown that structurally altered proteins serve as a signal for the induction of the stress protein 70 family (Munro and Pelham; 1986; Ananthan et al., 1986; Beckman, et al., 1990). Denaturation of proteins due to CrVI oxidation and/or aberrant translation of proteins caused by CrIII's action on nucleic acid tertiary structure may explain the induction of the $70-\mathrm{kD}$ protein.

A 32-kD stress protein known to be induced by arsenite, chromium, cationic heavy metals, and oxidizing agents has recently been identified to be heme oxygenase (Goering et al., 1987; Shibahara et al., 1987; Keyse and Tyrell, 1989; Ariyoshi et al., 1990; Mitani et al., 1990). This is an essential enzyme in heme catabolism where it cleaves heme to form biliverdin. Biliverdin is subsequently converted to bilirubin via biliverdin reductase. These heme products have been shown to be efficient peroxyl radical scavengers as well as CrVI reductants (Stocker et al. 1987a; Stocker at al. 1987b; Nieboer and Jusys, 1988). Thus, it has been suggested that induction of heme oxygenase may serve as a protective response against oxidative damage (Goering et al, 1987; Keyse and Tyrell, 1989).

Little is known of the function of $20 \mathrm{kD}$ proteins. Several proteins in the 20-27 $\mathrm{kD}$ range observed in a variety of cell cultures have been shown to be phosphorylated during cell stress (Kim et al., 1984; Duncan, and Hershey, 1987; Regazzi et al., 1988). These phosphorylated proteins accumulate in the nucleus and other large sedimenting organelles where it is suggested that they perform their protective roles (Kim et al., 1984; Duband et al., 1986; Arrigo, 1987). 
As to which spieces of chromium may be most responsible for the stress response, data from this study suggest that CrIII is the likely candidate. The lack of a major induction of stress proteins at $12 \mathrm{~h}$, as measured by radiolabel incorporation, and a highly significant response at $96 \mathrm{~h}$, as determined via quantitative immunoblots, coincides well with that of the rapid bio-reduction of CrVI to CrIII (Niebor and Jusys, 1988). Thus, production of denatured proteins was less likely to be from CrVI's oxidative action than CrIII's influence on transcription and translation.

Results of this study as well as another with sodium arsenite that we have performed demonstrate that the stress protein response has potential to serve as a biochemical indicator of cellular and organismal stress. Future research with emphasis on immunological techniques and their calibration to chronic effects is needed to fully understand the limits of this cellular protective mechanism. Several investigations have shown that different suites of proteins are induced upon exposure to different stressors (Courgeon et al., 1984; Honda et al., 1986; Shelton et al., 1986; Bournias-Vardiabasis et al., 1990). Thus, additional studies utilizing antibodies to other stress proteins may reveal other relevant bioindicators of stress as well as help to further elucidate toxicant induced effects and mode of action. 


\section{Lindane Exposures}

Materials and methods

Ninety-day-old fathead minnows (Pimephales promelas) were obtained from a culture located at the University of North Texas. Fish used for the study were acclimated to $25^{\circ} \mathrm{C}$ and a $16 \mathrm{~L}: 8 \mathrm{D}$ photoperiod for at least $7 \mathrm{~d}$ and were fed frozen brine shrimp twice daily to satiation.

Prior to each test, a fresh solution of lindane (Supelco, Inc. Bellefonte, PA) was prepared in certified grade DMF. The toxicant was metered into a modified Mount-Brungs diluter via a Beckman syringe pump. All exposures were flowthrough where water volumes in each $6 \mathrm{~L}$ exposure chamber were exchanged 5-6 times daily.

Range-finding experiments were carried out to determine a range of lindane concentrations suitable for a definitive 96-h toxicity test (LC50) and to determine times to first signs of intoxication. Fish were exposed to lindane concentrations ranging from 6.6 to $214.7 \mathrm{ug} / \mathrm{L}$. Minnows exposed to concentrations ranging from 88.4 to $214.7 \mathrm{ug} / \mathrm{L}$ displayed first signs of intoxication within $6 \mathrm{~h}$ and persisted for another 12 to $24 \mathrm{~h}$. Behavioral signs of toxicity followed a progression where fish first displayed extreme hyperactivity, periodic muscle spasms alternating with lethargy, and lastly whole body spasms and loss of equilibrium. 
In order to determine the length of time required for stress protein induction, fish were exposed to $220.0 \pm 48.4$ ug lindane/L and sampled at $0,2,4$, $6,8,10$, and $12 \mathrm{~h}$. Three replicates of three fish each were sampled at each time interval. Immediately after sampling, fish were sacrificed and brain, gill, and striated muscle tissues were disected and respectively pooled within each treatment replicate. Tissues were metabolically labeled for $2 \mathrm{~h}$ with ${ }^{35} \mathrm{~S}$ methionine/cysteine. Incorporation of radiolabel into proteins was examined by SDS-PAGE and fluorography. Fluorograms showed that a $70-\mathrm{kD}$ band was maximally induced in all three tissues at $12 \mathrm{~h}$. Thus, $12 \mathrm{~h}$ was determined to be the appropriate sampling time in the subsequent concentration-response experiment.

To ascertain the concentration range in which gill, brain, and striated muscle tissue synthesize stress proteins, fish were exposed to five different lindane concentrations $(7.5 \pm 2.5 ; 18.7 \pm 2.8 ; 47.5 \pm 9.2 ; 84.3 \pm 19.9 ; 180.9 \pm 13.0 \mathrm{ug}$ lindane/L), plus control, and sampled at $12 \mathrm{~h}$. Each treatment was replicated four times. Thirteen fish were placed into each treatment replicate. Three fish were subsampled at $12 \mathrm{~h}$ and the remaining fish were exposed for $96 \mathrm{~h}$. Brain, gill and striated muscle tissues of subsampled fish were treated as in the induction study. Time to mortality was recorded every $24 \mathrm{~h}$. Metabolic labeling, sample preparation, SDS-PAGE, and quantitation were performed as stated in the heatshock experiment materials and methods. X-ray films used for quantitation were exposed to radiolabeled gels for $4 \mathrm{~d}$. Quantitative immunoblotting with brain, gill, and striated muscle tissues from $96-\mathrm{h}$ toxicity test survivors was performed using 
the protocol outlined in the chromate experiments.

Concentration effects on mortality were determined by parametric analysis of variance on arcsine transformed percent mortality data. Comparisons to controls were made by one-tailed Dunnett T tests. The LC50 and LC1 were determined by probit analysis. Stress protein intensities were analyzed nonparametrically due to heteroscedacity. Kruskal-Wallis analysis of variance on ranked intensity data was used to determine the significance of treatment effects (alpha $=0.05$ ) on specific stress protein intensities. Comparisons to controls were determined by one-tailed Dunnett $\mathrm{T}$ tests on ranked data. Spearman rank correlations were used to compare percent mortality to stress protein intensities. Data are presented in three-dimensional plots in order to fully illustrate intensity data for each of the stress proteins versus lindane concentration. Due to the high variability of ${ }^{35} \mathrm{~S}$-methionine/cysteine incorporation into some stress proteins, increased bar height above that of the controls should not be interpreted as being necessarily statistically significant. Data from the quantitative immunoblots were analyzed by parametric analysis of variance and one-tailed Dunnett's $T$ test on raw data.

All exposures used dechlorinated tap water. Ranges of alkalinity, hardness, and conductivity were $80-120 \mathrm{mg} \mathrm{CaCO} / \mathrm{L}, 100-140 \mathrm{mg} \mathrm{CaCO}_{3} / \mathrm{L}$, and 270-310 umhos, respectively. Mean dissolved oxygen and $\mathrm{pH}$ measured were $5.1 \pm 1.2 \mathrm{mg}$ $\mathrm{O}_{3} / \mathrm{L}$ and $7.70 \pm 0.02$, respectively. Each treatment was monitored for lindane concentration once a day during each test. Water from each treatment replicate 
was added to volume in a $250 \mathrm{ml}$ volumetric flask containing $10 \mathrm{ml}$ of pesticide grade hexane. Samples were mixed for 1 hour, followed by removal of the hexane fraction. A Tracor 560 Gas Chromatograph fitted with an electron capture detector and a SPB-5 (Supelco, Inc.) capillary column was used to determine lindane concentrations in the hexane extract. Percent extraction efficiencies were $96.5 \pm 17.5 \%(\mathrm{~N}=6)$.

Results

Lindane treatments caused significant changes in mortality (parametric AOV, $\mathrm{p}=0.0001$ ). Percent mortality was $2.5 \%$ in controls, 7.5 , and $18.7 \mathrm{ug}$ lindane/L. Mortality increased to $47.5,95.0$, and $100 \%$ in the highest three concentrations (47.5, 84.4, and 180.9 ug lindane/L). Dunnett's $\mathrm{T}$ tests revealed mortality was significantly greater in $47.5,84.3$, and 180.9 ug lindane/L treatments compared to controls. Probit analysis showed the LC50 to be $43.8 \mu \mathrm{g}$ lindane/L and the LC1 to be $12.6 \mu \mathrm{g}$ lindane/L.

The stress protein response was elicited slightly in brain, gill, and muscle tissue exposed to $219.3 \mu \mathrm{g}$ lindane/L. Four proteins with apparent molecular weights of 35, 56, 65, and $70 \mathrm{kD}$ were observed in the brain (Fig.17). Radiolabel incorporation into these proteins increased with time, reaching maximum levels at 12-h exposure. A similar pattern was seen in the striated muscle (Fig. 18). Increased isotope incorporation into three proteins of 56,70 , and $90 \mathrm{kD}$ was 


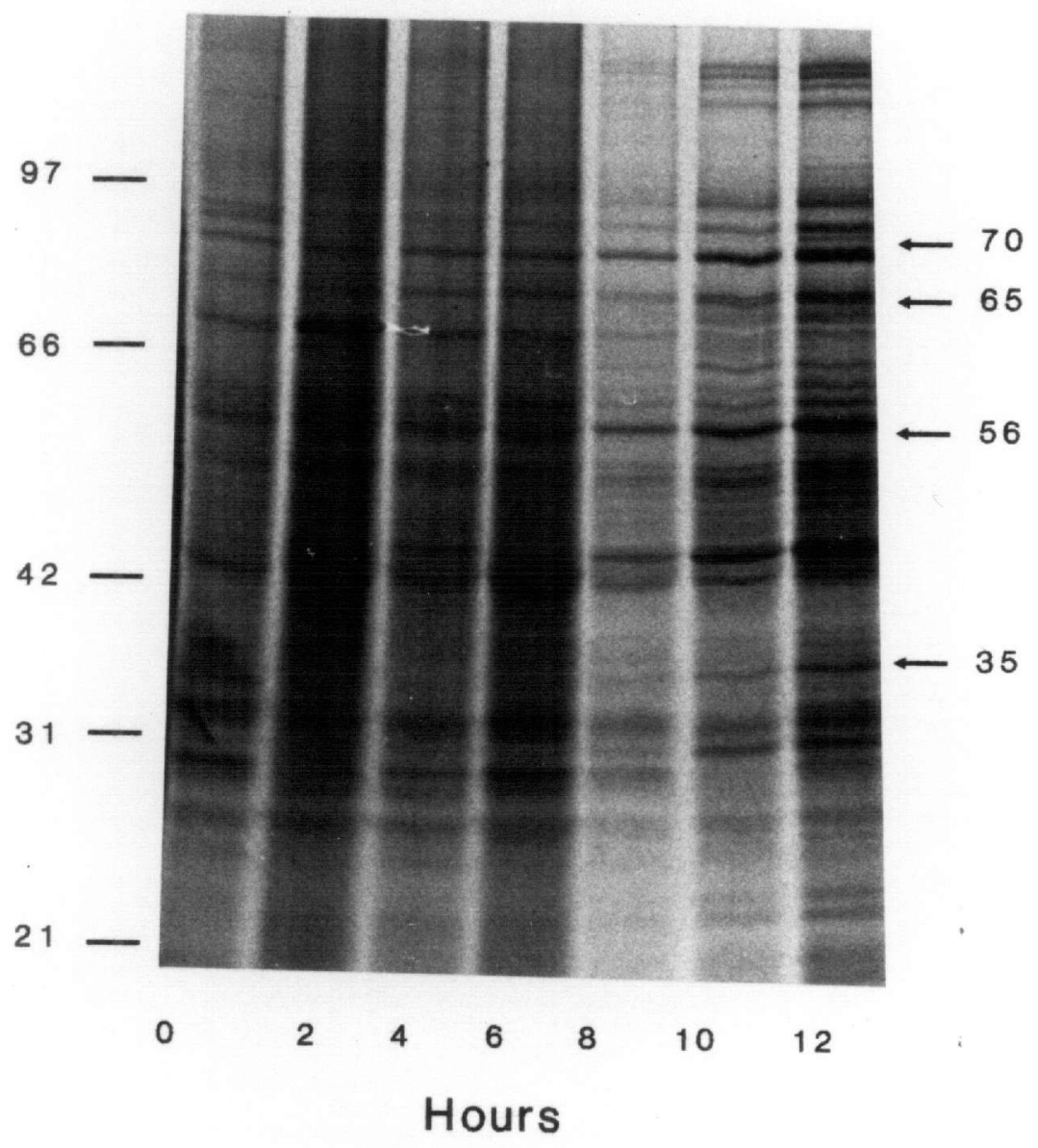

Figure 17. A fluorogram of brain tissue proteins from fish exposed to 220.0 ug lindane/L for $0,2,4,6,8,10$, and $12 \mathrm{~h}$. Molecular weight markers are designated on the left. Arrows on the right denote proteins of 35, 56, 65, and 70 $\mathrm{kD}$. 


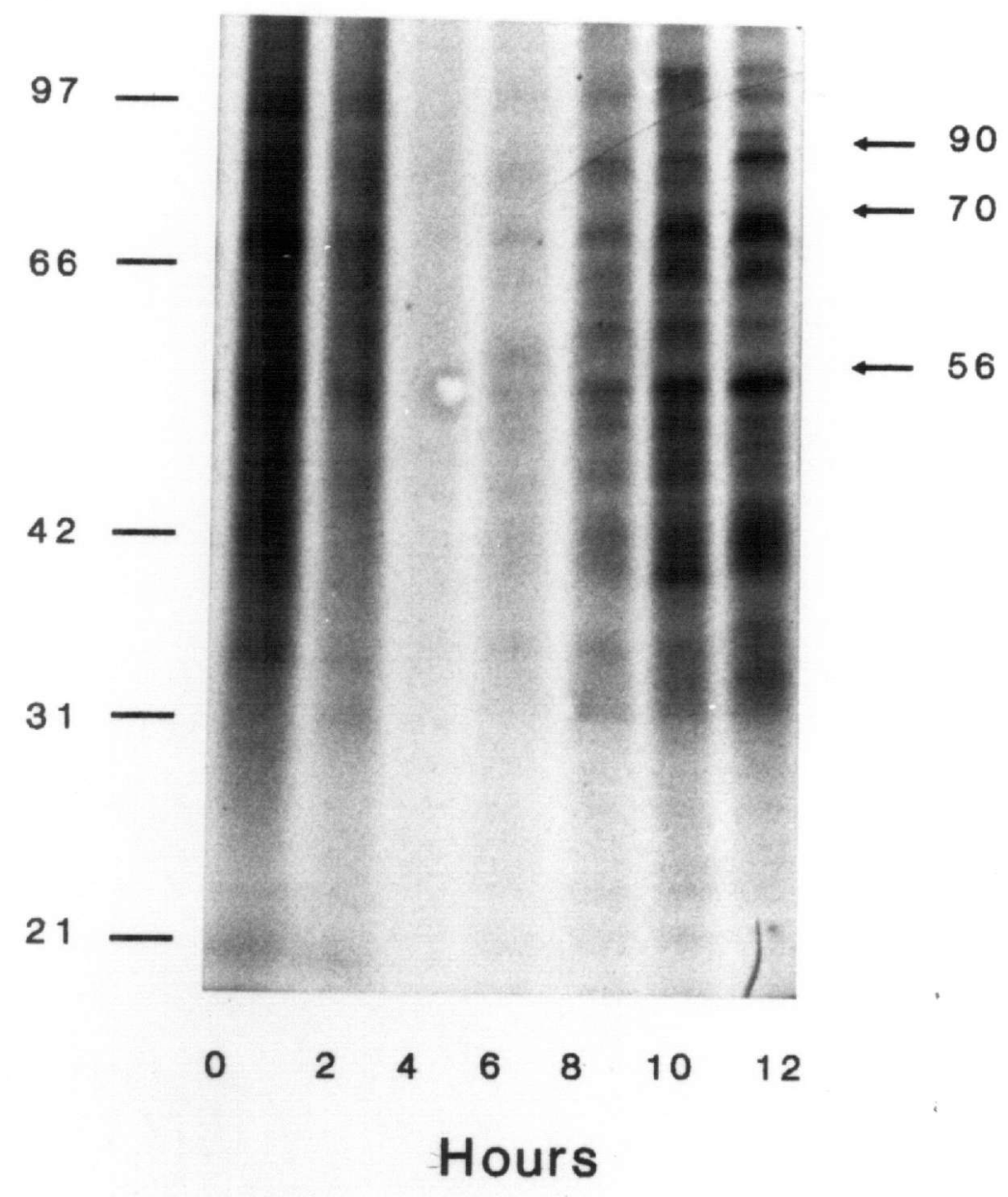

Figure 18. A fluorogram of striated muscle tissue proteins from fish exposed to 220.0 ug lindane/ $\mathrm{L}$ for $0,2,4,6,8,10$, and $12 \mathrm{~h}$. Molecular weight markers are designated on the left. Arrows on the right denote proteins of 56, 70, and $90 \mathrm{kD}$. 


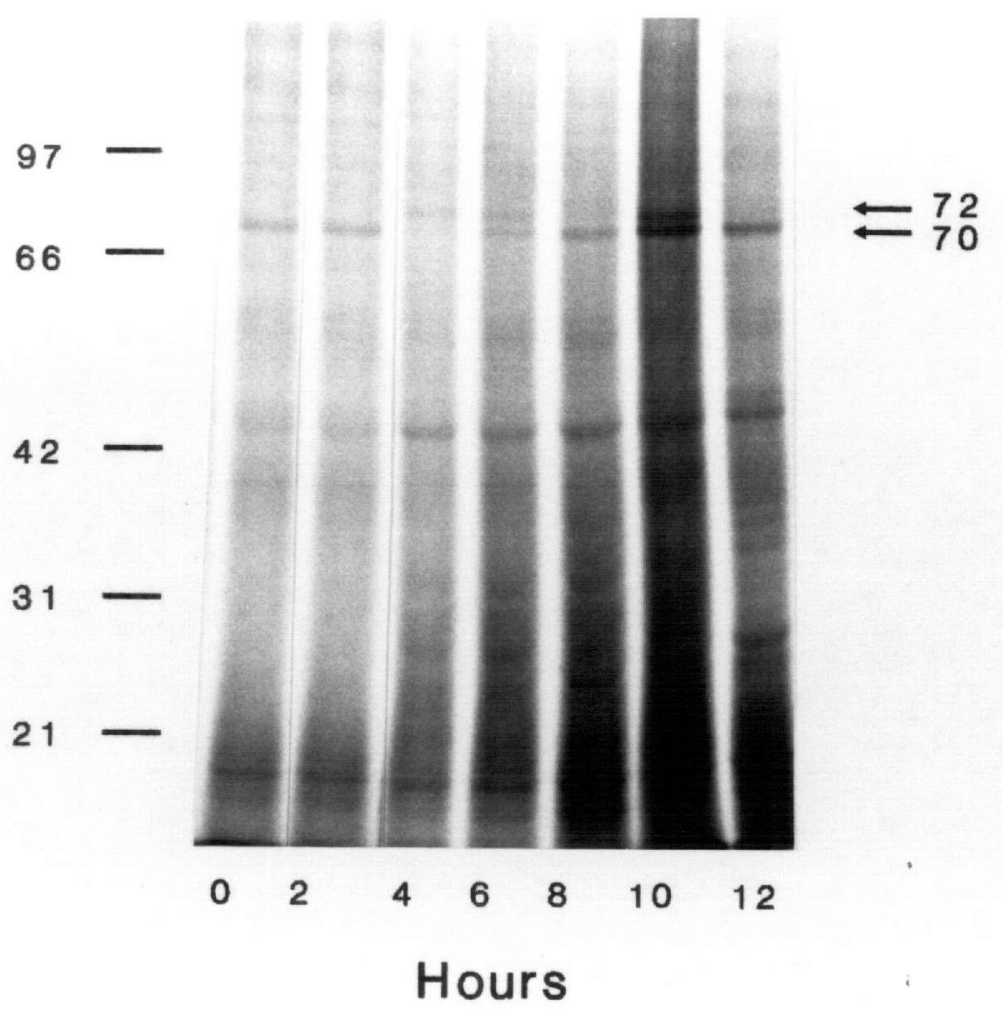

Figure 19. A fluorogram of gill tissue proteins from fish exposed to 220.0 ug lindane/L for $0,2,4,6,8,10$, and $12 \mathrm{~h}$. Molecular weight markers are designated on the left. Arrows on the right denote proteins of 70 and $72 \mathrm{kD}$. 
observed. As found in the muscle, maximum levels were reached by $12-\mathrm{h}$ exposure. In contrast, only two proteins, 70 and $72 \mathrm{kD}$, were observed in gill (Fig. 19). Increased label incorporation into the $72 \mathrm{kD}$ protein occured by $2 \mathrm{~h}$ and remained visible throughout the exposure period. Since maximal levels of induction occured at $12-\mathrm{h}$ exposure, this was deemed to be an appropriate sampling time for the concentration-response study. The goal was to correlate incorporation of radiolabel into stress proteins to an eventual effect, namely mortality.

Gill tissue of fathead minnows exposed to $7.5 \mu \mathrm{g}$ lindane/L responded by eliciting two proteins (70- and $72-\mathrm{kD}$ ) at incorporation rates significantly greater than controls (Figures 20A and 20B; Dunnett's T test, $\mathrm{p}<0.05$ ). However, over all other treatments, lindane did not significantly induce a stress response (Kruskal-Wallis, $\mathrm{p}=0.14$ ). Similarly, increased radiolabel incorporation into a 70 $\mathrm{kD}$ protein was evident at 18.7 and $47.5 \mu \mathrm{g}$ lindane/L in the brain (Figure $21 \mathrm{~A}$ and $21 \mathrm{~B})$. However, due to high variance at these concentrations there were no significant differences between controls. Nonparametric analysis of variance indicated that lindane had no effect on the stress protein response (KruskalWallis, $p=0.19$ ). In addition, Lindane treatments were not found to affect ${ }^{35} \mathrm{~S}$ label incorporation into a $70-\mathrm{kD}$ protein observed in the striated muscle (Figure 


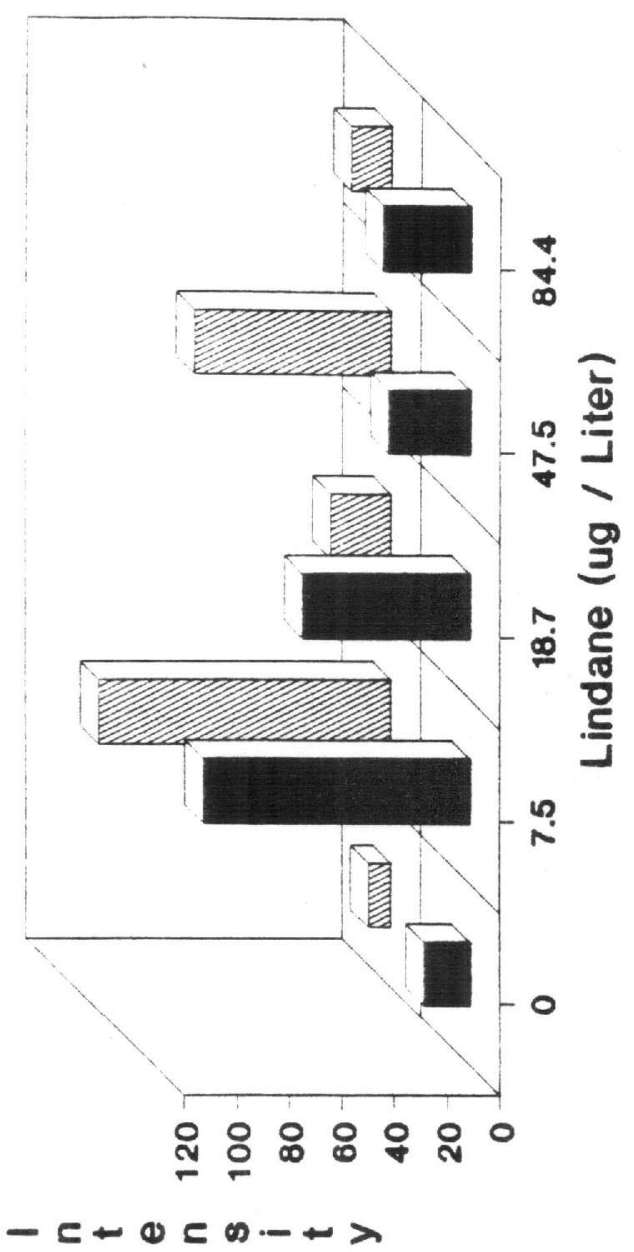

ำ

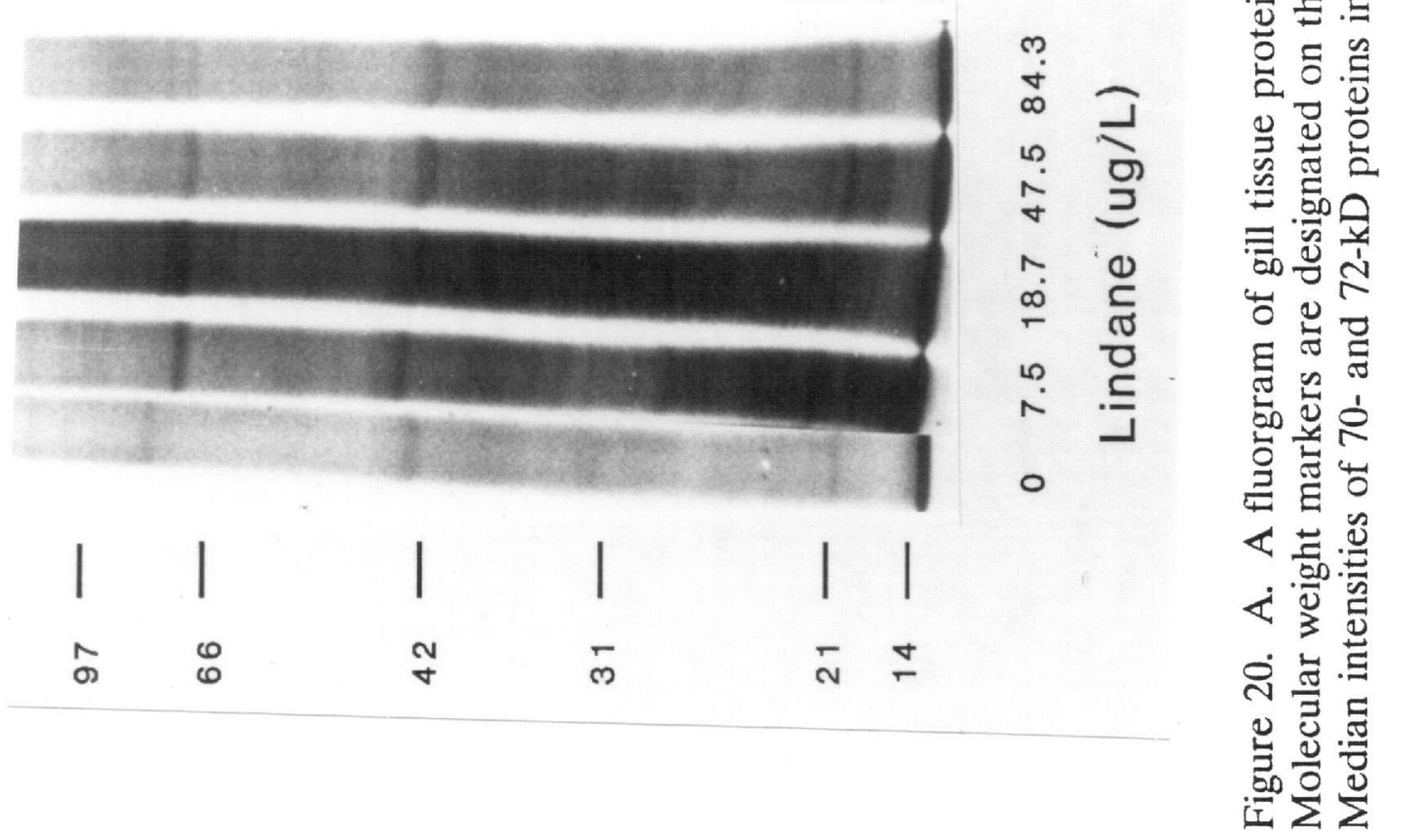




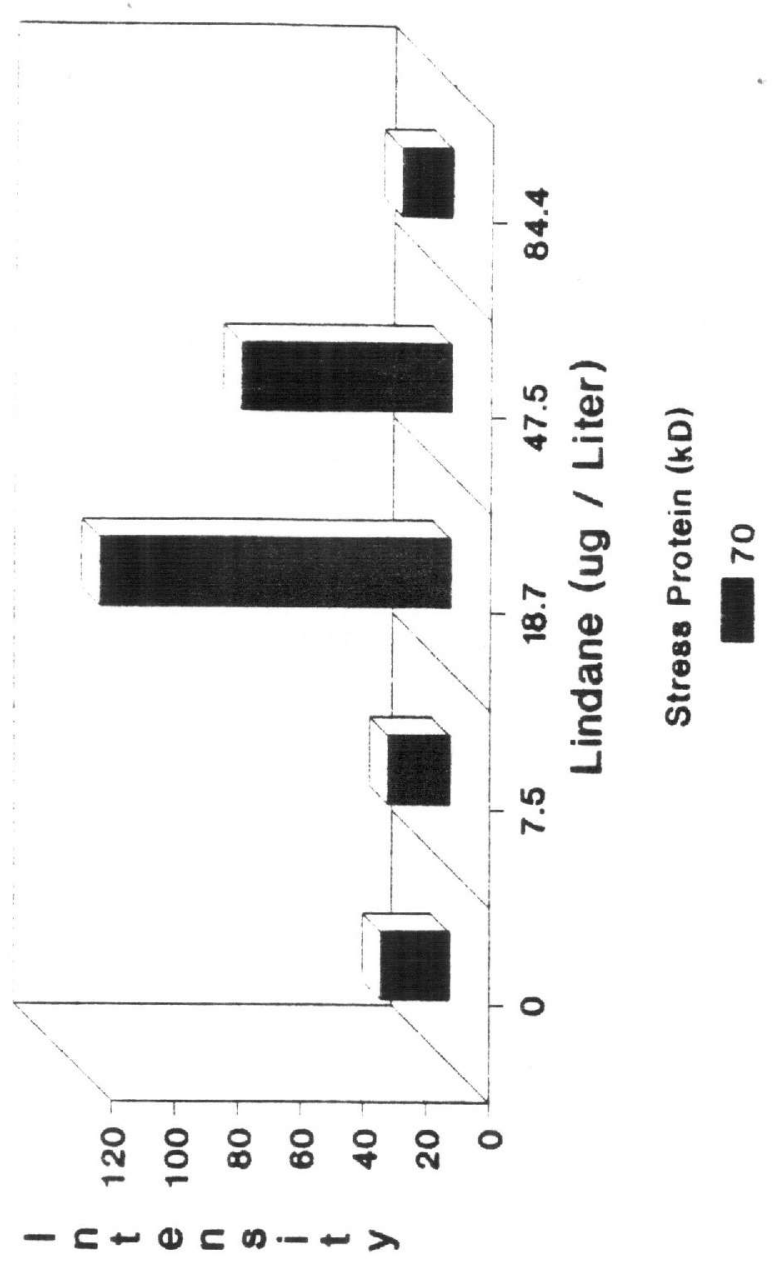

ปิ่ 它呅 实 몽를 Eㄴㅇㅇㅎㅇ 50.들 분 ๆ 음 品 胥令它

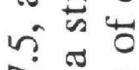
守守 กํํㅇ $\infty$ 过 vi 동 ० $\bigcirc \cong$ ปี ํㅡㅇ 전린 돈 $\Xi$ 틍 过 프용 은

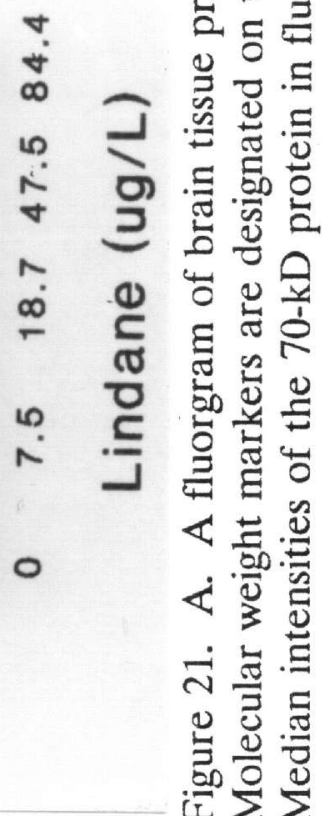

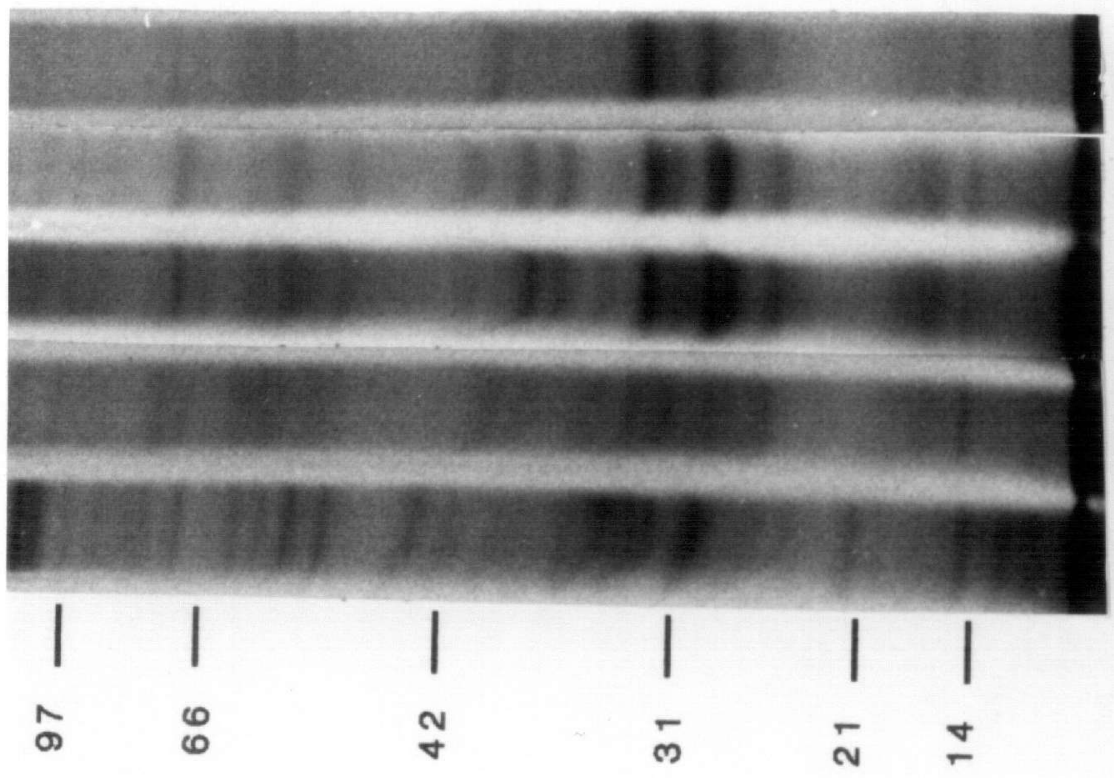




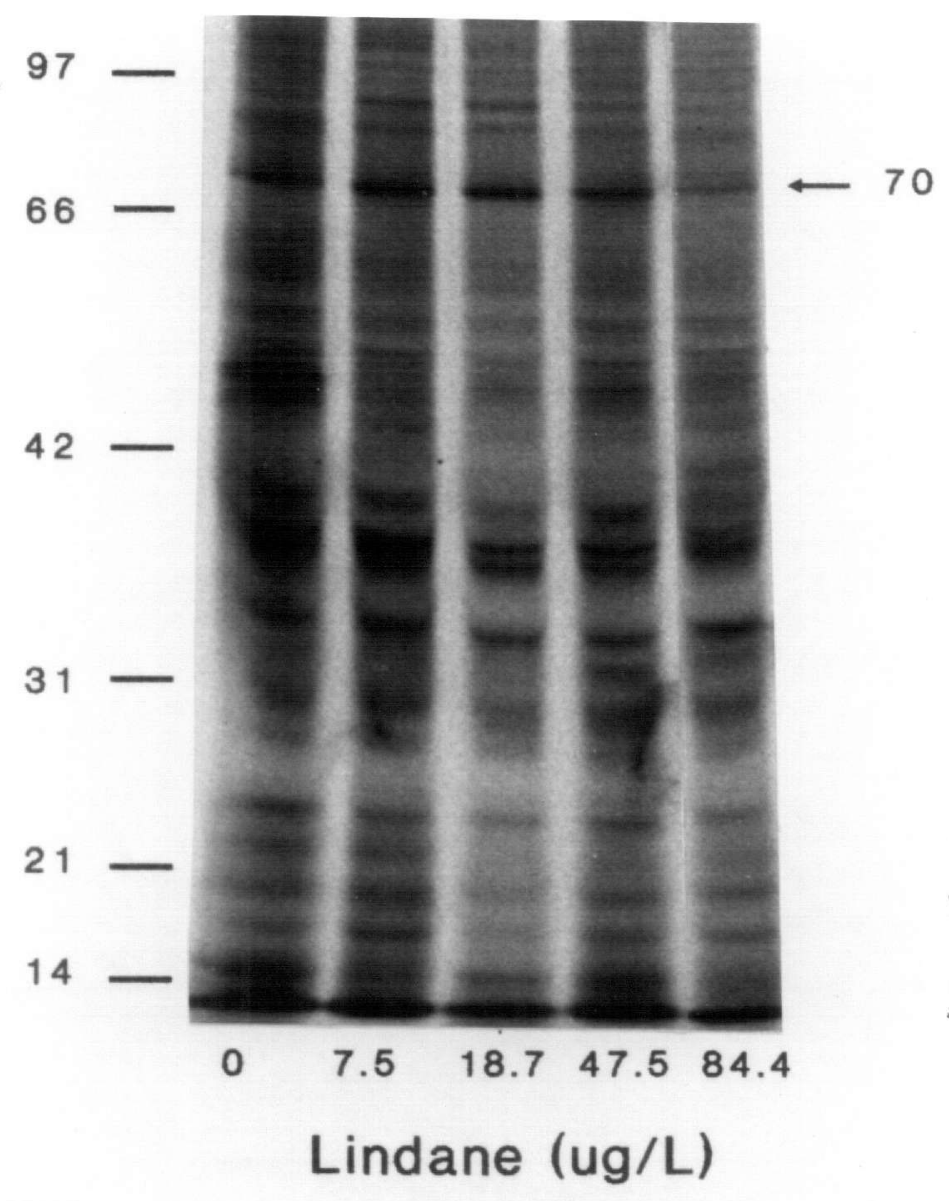

Figure 22A. A fluorogram of striated muscle tissue protein from fish exposed to $0,7.5,18.7,47.5,84.3 \mathrm{ug}$ lindane/L for $12 \mathrm{~h}$. Molecular weight markers are designated on the left. The arrow on the right denotes a stress protein of $70 \mathrm{kD}$. 


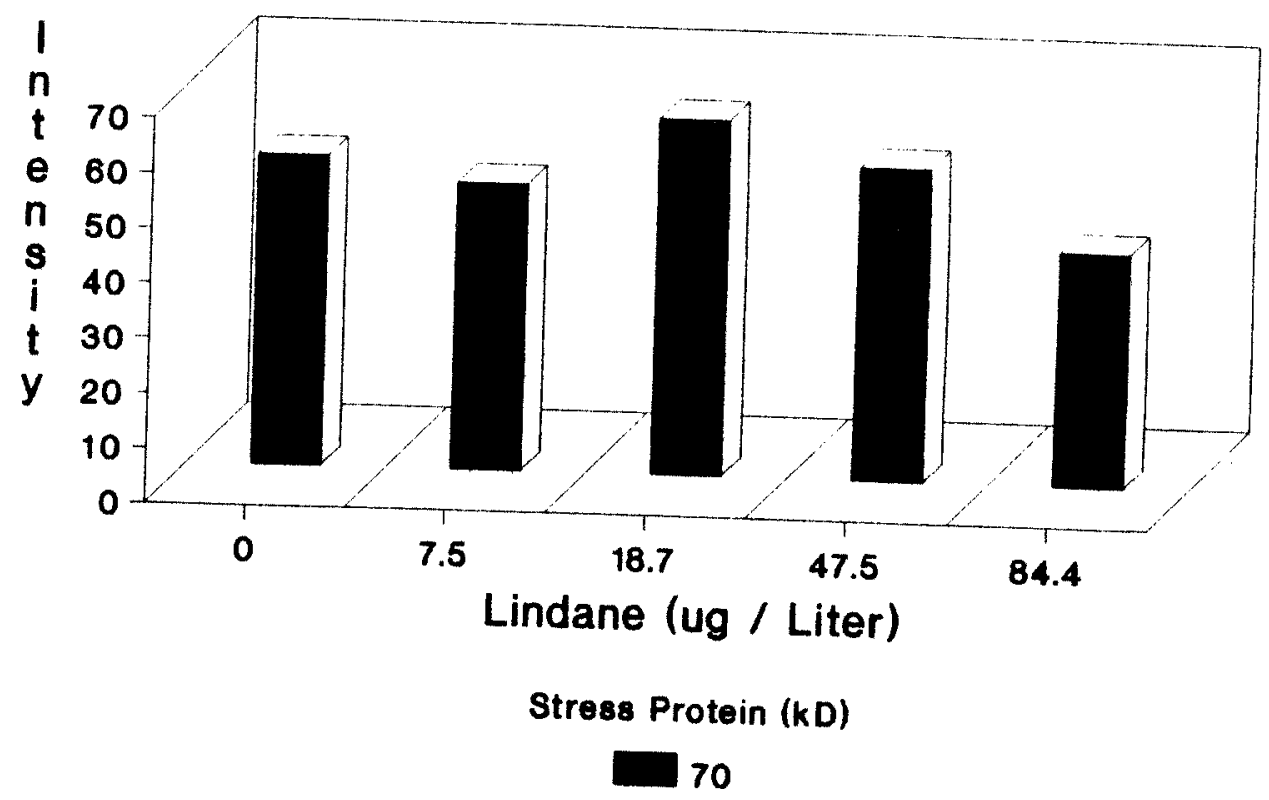

Figure 22B. Median intensities of the $70-\mathrm{kD}$ protein in fluorograms from replicate samples $(n=4)$ from the experiment described in $22 \mathrm{~A}$.

22A and 22B; Kruskal-Wallis, $\mathrm{p}=0.51$ ).

Brain, gill, and striated muscle protein of 96-h survivors were immunoblotted with an antibody to hsp 72/73. One band, with an apparent molecular weight of $70-\mathrm{kD}$, was found in each of the tissues. The mean number of micrograms of total protein required for minimum detection in gill was decreased in all lindane treatments, as compared to control levels. Parametric analysis of variance showed that lindane concentrations significantly affected 70 $\mathrm{kD}$ protein levels in gill $(\mathrm{p}=0.0008)$. Lindane had no significant affect on $\mathrm{sp70}$ accumulations in brain and striated muscle tissue. 


\section{Stress Protein 70 Levels and Percent Mortality vs. Lindane Concentration}

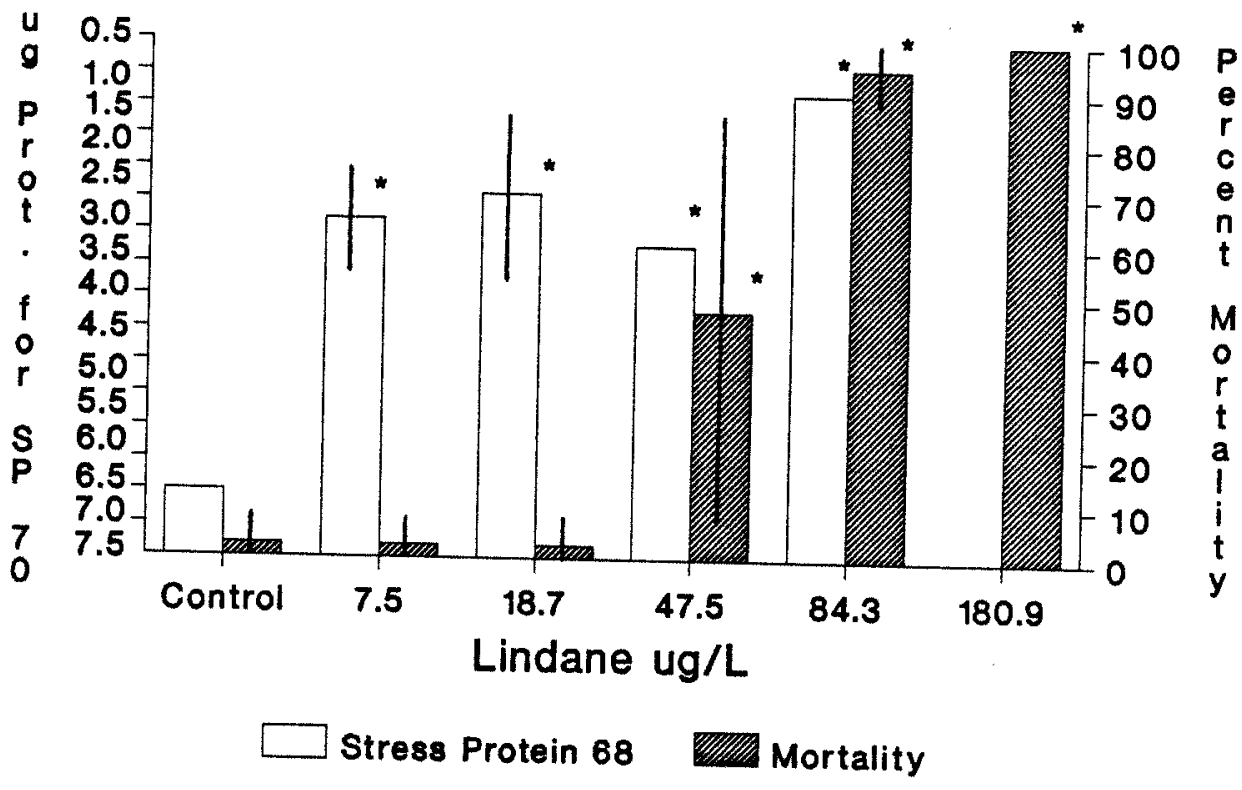

Figure 23. Histograms that illustrate the relationships of the $70-\mathrm{kD}$ gill protein, as determined by quantitative immunoblots, and percent mortality of fish exposed to different lindane concentrations for $96 \mathrm{~h}$. Open bars correspond to mean number of micrograms of total protein required for minimum stress protein detection \pm standard deviation. Hatched bars correspond to mean percent mortality \pm SD. Asterix denote significance from controls, as determined by Dunnett's $\mathrm{T}$ tests.

A Dunnett's T test performed on raw data from the gill showed that lindane significantly decreased the minimum detection level for the $70-\mathrm{kD}$ protein at all treatment levels. However, $70-\mathrm{kD}$ protein levels were not significantly correlated with 96-h mortality (Pearson correlation, $\mathrm{p}=0.22, \mathrm{r}=-0.35$ ). 
Discussion

The translation patterns in three tissues (brain, gill, and striated muscle) of the fathead minnow were found to be affected upon acute exposure to $219.3 \mu \mathrm{g}$ lindane/L. By $12 \mathrm{~h}$, increased radiolabel incorporation into four proteins $(35,56$, $65,70 \mathrm{kD}$ ) in the brain, three $(56,70,90 \mathrm{kD})$ in the striated muscle, and two (70 and $72 \mathrm{kD}$ ) in the gill were observed. In contrast, only one protein band, corresponding to $70 \mathrm{kD}$, was observed in the brain and muscle tissues of fish exposed to a wide range of lindane concentrations. However, both the 70 and 72 $\mathrm{kD}$ proteins were observed in gill of fish exposed to a range of lindane concentrations, as found in the time to induction study. Statistically, lindane did not affect radiolabel incorporation into the above mentioned proteins in any of the tissues.

Blots with protein from brain, gill, and striated muscle of $96-\mathrm{h}$ toxicity test survivors revealed a single band with an apparent molecular weight of $70 \mathrm{kD}$. Only levels found in the gill were significantly affected by lindane concentration. Accumulation of the $70 \mathrm{kD}$ stress protein observed in gill was significantly increased in fish exposed to all lindane treatment levels $(7.5,18.7,47.5,84.3$, and 180.9 ug lindane/L). Mortality, however, was found to be significantly greater than controls at lindane concentrations of $47.5,84.3$, and 180.9 ug lindane/L. Thus, a comparison between stress protein 70 accumulation and mortality revealed that accumulation of the $70 \mathrm{kD}$ stress protein was six-fold more sensitive than $96-\mathrm{h}$ percent mortality. 
Future use of quantitative immunoblots to ascertain chronic toxicant exposure appears to have great potential. For example, significantly increased 70$\mathrm{kD}$ protein accumulation in the gill occurred at a concentration below that of the $\mathrm{LC} 1,12.6 \mu \mathrm{g}$ lindane/L. In addition, Sanders et al., (in press) has shown that sp60 accumulation in mantle tissue of the mollusc Mytilus edulis is an order of magnitude more sensitive than scope for growth, a whole organism index of health.

At present, relationships of the stress protein response and insecticide exposure have thus far been ignored. Our study demonstrated the presence of a 70-kD stress protein in brain, gill, and striated muscle tissues. In regard to its function, much is known about sp70. This stress protein has been shown to have at least three functions, multimeric protein assembly, unfolding for translocation and disaggregation of protein aggregates (Craig, 1989; Rothman 1989; Welch, 1990; Schlesinger, 1990). These functions are thought to facilitate repair of proteins and protein complexes associated with common and critical metabolic processes and thus protect cells from stressor induced damage. In addition, it has been shown that this $70 \mathrm{kD}$ protein interacts with proteins involved with cytoskeletal structure and function (Clark and Brown, 1986; Guidon and Hightower, 1986; Whatley et al., 1986; Green and Liem, 1989). Several studies have shown that structurally altered proteins serve as a signal for the induction of stress protein 70 (Munro and Pelham, 1986; Ananthan et al., 1986; Beckman et al., 1990). However, how this relates to the accumulation of stress protein 70 in 
the gill and the mode of action of lindane is not obvious.

It is generally accepted that the toxicity of lindane is a result of its inhibition of the GABA - activated chloride channel in the nerve (Matsumura and Ghiasuddin, 1983; Woolley and Zimmer, 1986; Fishman and Gianutsos, 1987; Joy et al., 1987; Ogata et al., 1988). Organochlorine insecticides such as lindane, cyclodienes, and toxaphene inhibit GABAergic transmission by binding to a site associated with the GABA-Cl channel complex. GABA inhibition results in the presynaptic release of neurotransmitter (Shankland, 1982; Woolley and Zimmer, 1986; Joy et al., 1987). Postsynaptically, lindane has been found to reduce sensitivity of the end plate to acetylcholine (Woolley and Zimmer, 1986). Chemically, lindane is highly lipophilic. Although it has not been shown to disorder fluid native membranes, it has been hypothesized that lindane may interfere with the physico-chemical properties of integral proteins in discrete membrane domains (Antunes-Madeira and Madeira, 1989).

In aquatic organisms, lindane has been shown to: disrupt osmoregulatory mechanisms, particularly chloride regulation, in the crab Eurypanopeus depressus (Shirley and McKenney, 1987), induce hypoglycemia and alter the membrane lipidic matrix in carp Cyprinus carpio (Demael et al., 1987); and inhibit protein synthesis in Tetrahymena pyriformis (Al-Chalabi and Al-Khayat, 1989). In addition, neonates of Daphnia magna exposed to different concentrations of chlordecone, a cyclodiene insecticide, showed decreased protein/organism with increased exposure concentration (McKee and Knowles, 1986). 
Given the affinity of stress protein 70 for denatured proteins and protein repair, including those involved in cytoskeletal structure, and lindane's effects on membrane processes, leads to the suggestion that the lindane-induced stress response is due to membrane associated aberrations. 


\section{Diazinon Exposures}

Materials and methods

Ninety to 120-day-old fathead minnows (Pimephales promelas) were obtained from a culture located at the University of North Texas. Fish used for the study were acclimated to $25^{\circ} \mathrm{C}$ and a $16 \mathrm{~L}: 8 \mathrm{D}$ photoperiod for at least $7 \mathrm{~d}$ and were fed frozen brine shrimp twice daily to satiation.

Stock concentrations of Diazinon (Supelco, Inc., Bellefonte, PA) were prepared in certified grade DMF. All exposures were static/renewal. Before exposing fish to the insecticide, a degradation study was performed to determine frequency of renewals. A $19 \mathrm{~L}$ glass aquaria filled to $18 \mathrm{~L}$ with dechlorinated tap water was spiked with $4.4 \mathrm{ml}$ of a $24,533 \mathrm{mg}$ diazinon/L stock solution such that the nominal concentration in the stock tank was $6 \mathrm{mg} / \mathrm{L}$. The stock tank was then gently stirred with a glass rod. The contents were transferred into four $6 \mathrm{~L}$ glass aquaria, each fitted with a center drain pipe positioned so that the overflow volume was $5 \mathrm{~L}$. The aquaria were filled until overflowing. Samples from each aquaria were taken at $0,2,4,8,12$, and $24 \mathrm{~h}$. Aqueous diazinon concentrations remained stable for $12 \mathrm{~h}$, but dropped unacceptably by $24 \mathrm{~h}$ (Fig. 24). Therefore, the maximum time to next renewal was determined to be $12 \mathrm{~h}$. For fish exposures, appropriate volumes of stock solution were pipetted into 19L (stock) tanks using the degradation study protocol. Ninety-percent of the exposure volume was renewed every $12 \mathrm{~h}$. 


\section{Results of the Diazinon Degradation Study}

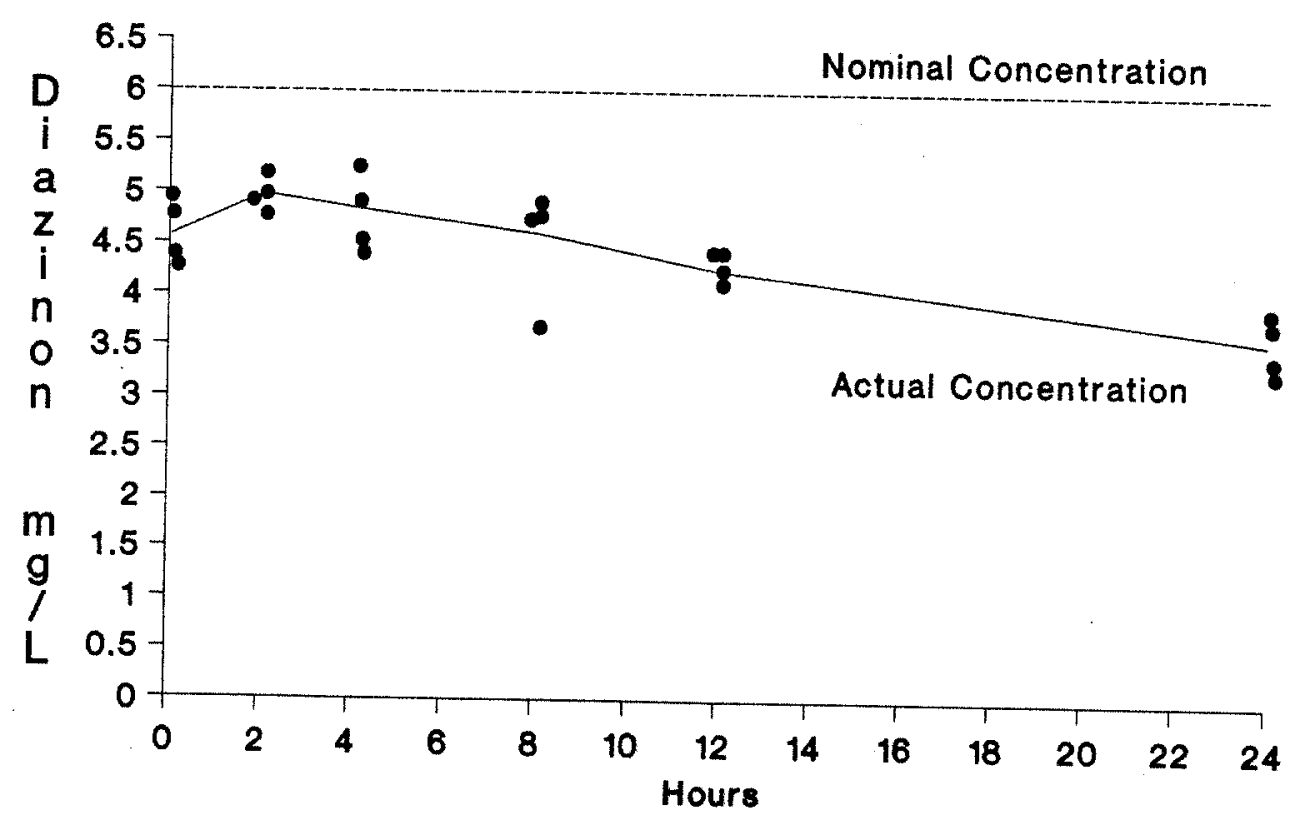

Figure 24. A scatter plot of actual diazinon concentrations in static aquaria sampled at $0,2,4,8,12$, and $24 \mathrm{~h}$. Solid line connects mean diazinon concentration respective of sampling time. The dashed line corresponds to the nominal, spike, concentation.

A range-finding experiment was performed to determine a range of diazinon concentrations suitable for a definitive LC50 test and to determine times to first signs of intoxication. Five diazinon concentrations $(2,4,6,8$, and $10 \mathrm{mg} / \mathrm{L}$, nominal) were used. Each treatment was replicated twice. Four to six fish were placed into each treatment replicate and observed for onset of intoxication. By 
$4 \mathrm{~h}$, fish in all treatments showed varying degrees of intoxication. Fish in the 2 and $4 \mathrm{mg}$ Diazinon/L treatments were lethargic and located on the bottom of the aquaria. In contrast, 6,8 , and $10 \mathrm{mg} / \mathrm{L}$ exposed fish were near the surface operculating rapidly and displayed erratic swimming, including lazy ' $S$ ' curves. By $24 \mathrm{~h}$, percent mortality was $33 \%$ and $67 \%$ in 8 and $10 \mathrm{mg} / \mathrm{L}$ exposed fish, respectively, however, none had died in the other treatments.

To determine the length of time required for induction of the stress proteins, two replicates of three fish each were exposed to $8 \mathrm{mg} / \mathrm{L}$ (nominal) and sampled at $0,4,8,12$, and $24 \mathrm{~h}$. Immediately after sampling, fish were sacrificed. Gill $(37.1 \pm 8.0 \mathrm{mg})$, brain $(22.4 \pm 3.3 \mathrm{mg})$ and striated muscle tissue $(36.3 \pm 6.2$ $\mathrm{mg}$ ) were excised and respectively pooled within each treatment replicate. Tissues were metabolically labeled for $2 \mathrm{~h}$ with ${ }^{35} \mathrm{~S}$-methionine/cysteine (Trans ${ }^{35} \mathrm{~S}$-label, ICN). Incorporation of label into proteins was examined by SDS-PAGE and fluorography. Resulting fluorograms showed that all stress induced proteins observed within the $24-\mathrm{h}$ treatment period were maximally induced at $12 \mathrm{~h}$. Thus, $12 \mathrm{~h}$ was selected as the sampling time to examine the stress protein response in the subsequent $96-\mathrm{h}$ acute toxicity test.

The range of concentrations in which the gill and striated muscle elicit the stress response was determined by exposing fish to five different diazinon concentrations $(1.44 \pm 0.21 ; 2.46 \pm 0.51 ; 3.45 \pm 0.80 ; 3.79 \pm 0.49 ; 5.59 \pm 0.50 \mathrm{mg}$ diazinon/L) plus control, and sampled at $12 \mathrm{~h}$. Each treatment was replicated four times. Thirteen fish were placed into each treatment replicate. Three were 


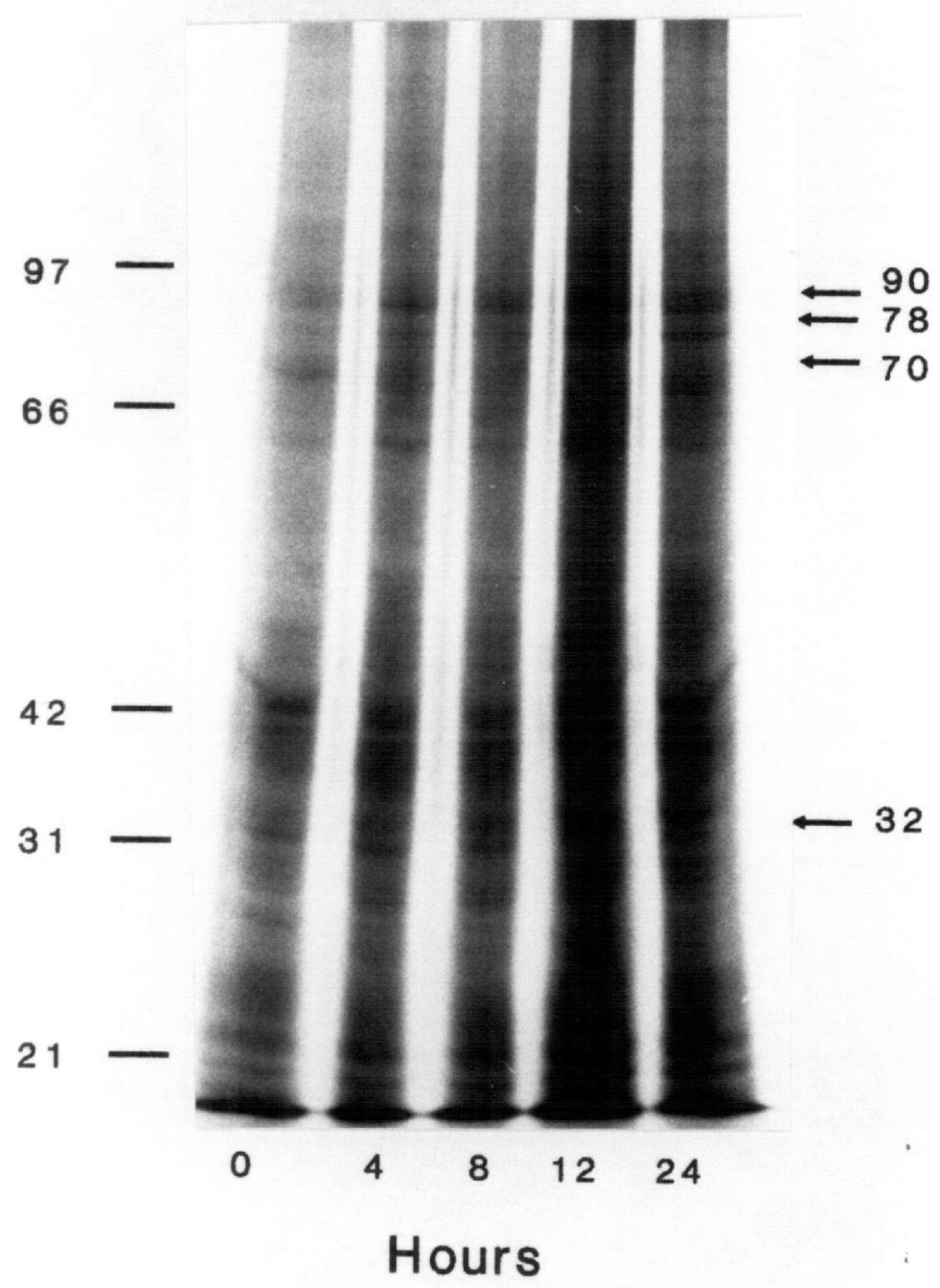

Figure 25. A fluorogram of gill tissue proteins from fish exposed to $8 \mathrm{mg}$ diazinon/L (nominal) for $0,4,8,12$ and $24 \mathrm{~h}$. Molecular weight markers are designated on the left. Arrows on the right denote proteins of 32, 70, 78, 90, 70 and $96 \mathrm{kD}$. 


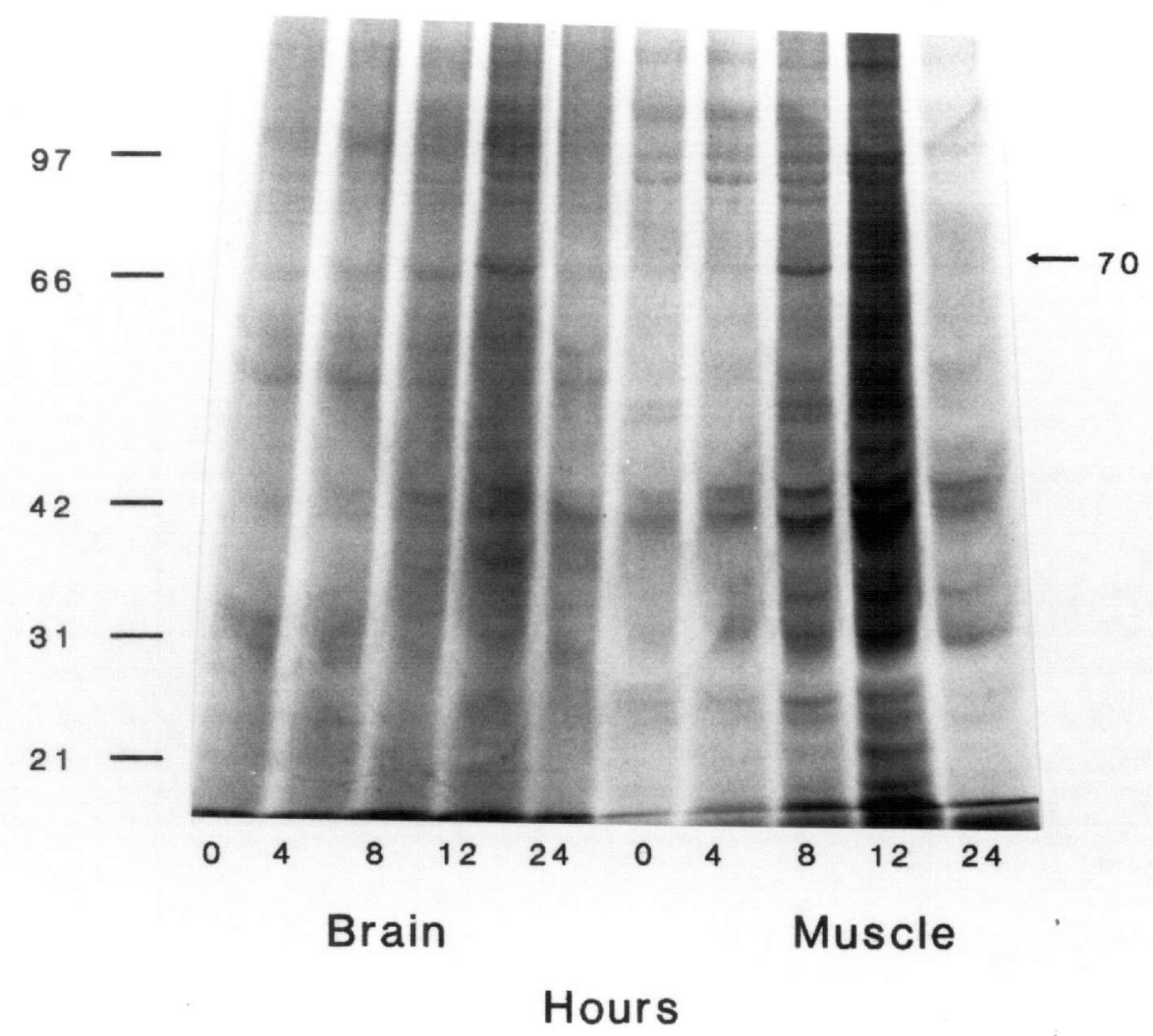

Figure 26. A fluorogram of brain and striated muscle tissue proteins from fish exposed to $8 \mathrm{mg}$ diazinon/L (nominal) for $0,4,8,12$ and 24h. Molecular weight markers are designated on the left. Arrow on the right denotes a protein of 70 $\mathrm{kD}$. 
subsampled at $12 \mathrm{~h}$ and the remaining fish were exposed for $96 \mathrm{~h}$. Tissues of subsampled fish (gill, $40.6 \pm 6.3 \mathrm{mg}$; brain, $27.0 \pm 10.0 \mathrm{mg}$; striated muscle $44.6 \pm$ $7.1 \mathrm{mg}$ ) destined for metabolic labeling were treated as mentioned in the induction study. Time to mortality was recorded every $24 \mathrm{~h}$. Metabolic labeling, sample preparation, SDS-PAGE, and quantitation of fluorograms was conducted using protocols described in the heat shock experiment's materials and methods.

In addition, allocation of incorporated radiolabeled amino acids in brain and striated muscle samples was assessed via radiation-normalized gels. Samples were precipitated with $72 \%$ trichloroacetic acid and then centrifuged at $3,000 \mathrm{~g}$ for 15 minutes. The supernatent was discarded. The resulting pellet was suspended at $95^{\circ} \mathrm{C}$ in sample buffer containing $4 \mathrm{M}$ Urea. Fifteen microliters from each sample was counted for radioactivity using a Beckman LS-100 scintillation counter. Amount of sample destined for SDS-PAGE and fluorography was normalized to $150,000 \mathrm{cpm}$.

Concentration effects on mortality were determined by parametric analysis of variance on arcsine transformed percent mortality data. Comparisons to controls were made by one-tailed Dunnett T tests. The LC50 and LC1 were determined by probit analysis. Stress protein intensities were analyzed nonparametrically due to heteroscedacity. Kruskal-Wallis analysis of variance on ranked intensity data was used to determine the significance of treatment effects $($ alpha $=0.05)$ on specific stress protein intensities. Comparisons to controls were determined by one-tailed Dunnett $\mathrm{T}$ tests on ranked data. Linearity of intensities 
of stress-induced proteins versus diazinon concentration was determined via regression analysis of $\log$ transformed intensity data vs. diazinon concentration.

All exposures used dechlorinated tap water that had the following mean

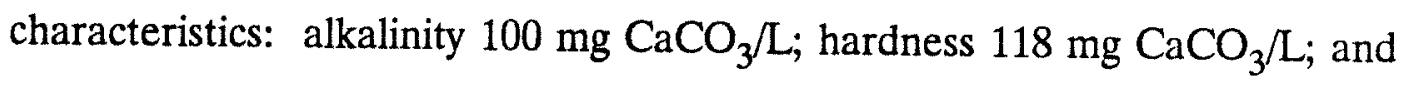
conductivity 300 umhos. Dissolved oxygen $(4.2 \pm 0.8 \mathrm{mg} \mathrm{O} / \mathrm{L})$ and $\mathrm{pH}(7.2 \pm 0.2)$ were measured at the end of each renewal. Each treatment was monitored for diazinon concentration once a day during each test. Water from each treatment replicate was added to volume in a $250 \mathrm{ml}$ volumetric flask containing $25 \mathrm{ml}$ of pesticide grade hexane. Samples were mixed for 1 hour, followed by removal of the hexane fraction. A Tracor 560 Gas Chromatograph fitted with an electron capture detector and a SPB-5 (Supelco, Inc.) capillary column was used to determine diazinon concentrations in the hexane extract. Percent spike recoveries were $102.2 \pm 13.6 \%(\mathrm{~N}=6)$.

Results

A range of diazinon concentrations caused significant changes in mortality (parametric AOV, $\mathrm{p}=0.0001$ ). Mean percent mortalities were 4.9, 0.0, 5.0, 7.5, 20.0 , and $75.0 \%$ at diazinon concentrations of $0,1.4,2.4,3.4,3.8$, and $5.6 \mathrm{mg}$ diazinon/L. A Dunnett's T test revealed that the 3.8 and $5.6 \mathrm{mg} / \mathrm{L}$ treatments had significantly greater mortalities compared to controls $(\mathrm{p} \leq 0.05)$. Probit analysis determined the LC50 to be $4.74 \mathrm{mg} / \mathrm{L}$ and the $\mathrm{LC} 1$ to be $2.38 \mathrm{mg} / \mathrm{L}$.

Gill tissue of fathead minnows exposed to $8 \mathrm{mg}$ diazinon/L (nominal) 
elicited the stress response (Fig. 25). Five stress proteins with apparent molecular weights of $32,70,78,90$, and $96 \mathrm{kD}$ were observed. Radiolabeled methionine/cysteine incorporation into all proteins increased beyond 0 -h rates by $8 \mathrm{~h}$ exposure and reached maximum rates at $12 \mathrm{~h}$. Compared to 12 - $\mathrm{h}$ rates, there was a decrease in label incorporation at $24 \mathrm{~h}$. Similar kinetics of protein induction was observed in the brain and striated muscle (Fig. 26). Both tissues elicited a 70 $\mathrm{kD}$ protein. As found with gill, maximum incorporation of ${ }^{35} \mathrm{~S}$-methionine/cysteine occurred at $12 \mathrm{~h}$, with an apparent decrease at $24 \mathrm{~h}$. Therefore, a $12-\mathrm{h}$ exposure was selected to be the sampling time for the concentration-response study.

The stress response was found to be highly tissue specific in fish exposed to. a range of diazinon concentrations. Total numbers and molecular weights of stress induced proteins observed differed markedly between the gill, brain and striated muscle tissues. In addition, the range of concentrations required for the increased incorporation of radiolabel into proteins of similar molecular weight was also tissue specific.

Five stress induced proteins were observed in the gill (Fig. 27). A visual inspection of one of the replicate fluorograms shows that ${ }^{35} \mathrm{~S}$-methionine/cysteine incorporation into proteins of 70 and $78 \mathrm{kD}$ increased above controls from 1.4 to $5.6 \mathrm{mg} / \mathrm{L}$. A $32 \mathrm{kD}$ protein showed an increase from 3.4 to $5.6 \mathrm{mg} / \mathrm{L}$ whereas, the $96-\mathrm{kD}$ protein appeared only at the highest concentration. In contrast, the $90-\mathrm{kD}$ protein did not appear to be induced above controls at any diazinon concentration. Kruskal-Wallis analysis of variance of densitometric scans of all 


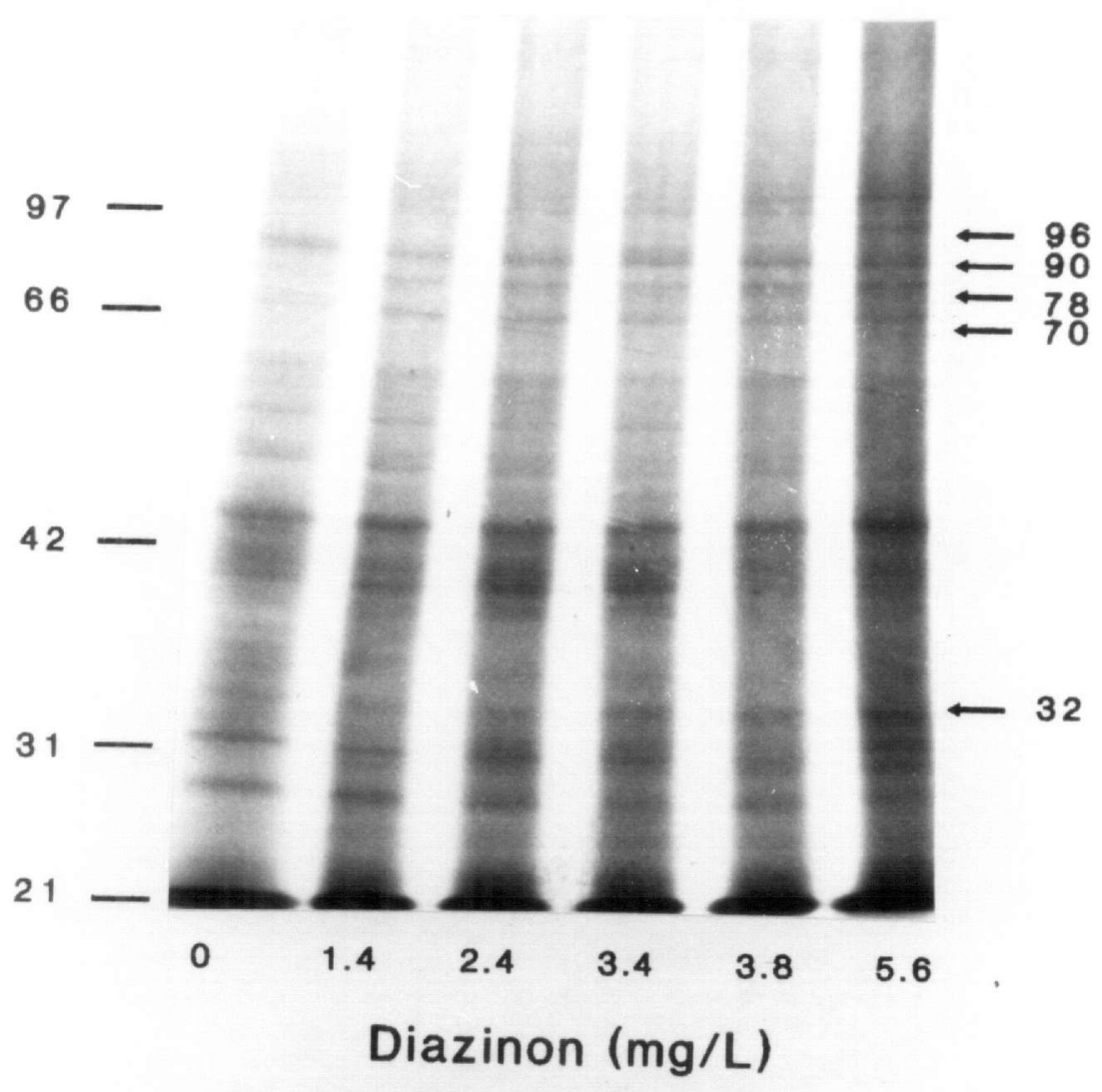

Figure 27. A fluorogram of gill tissue protein of fathead minnows exposed to 0 , $1.4,2.4,3.4,3.8$, and $5.6 \mathrm{mg}$ diazinon/L for $12 \mathrm{~h}$. Molecular weight markers are designated on the left. The arrows on the right denote proteins of $32,70,78,90$, $96 \mathrm{kD}$. 


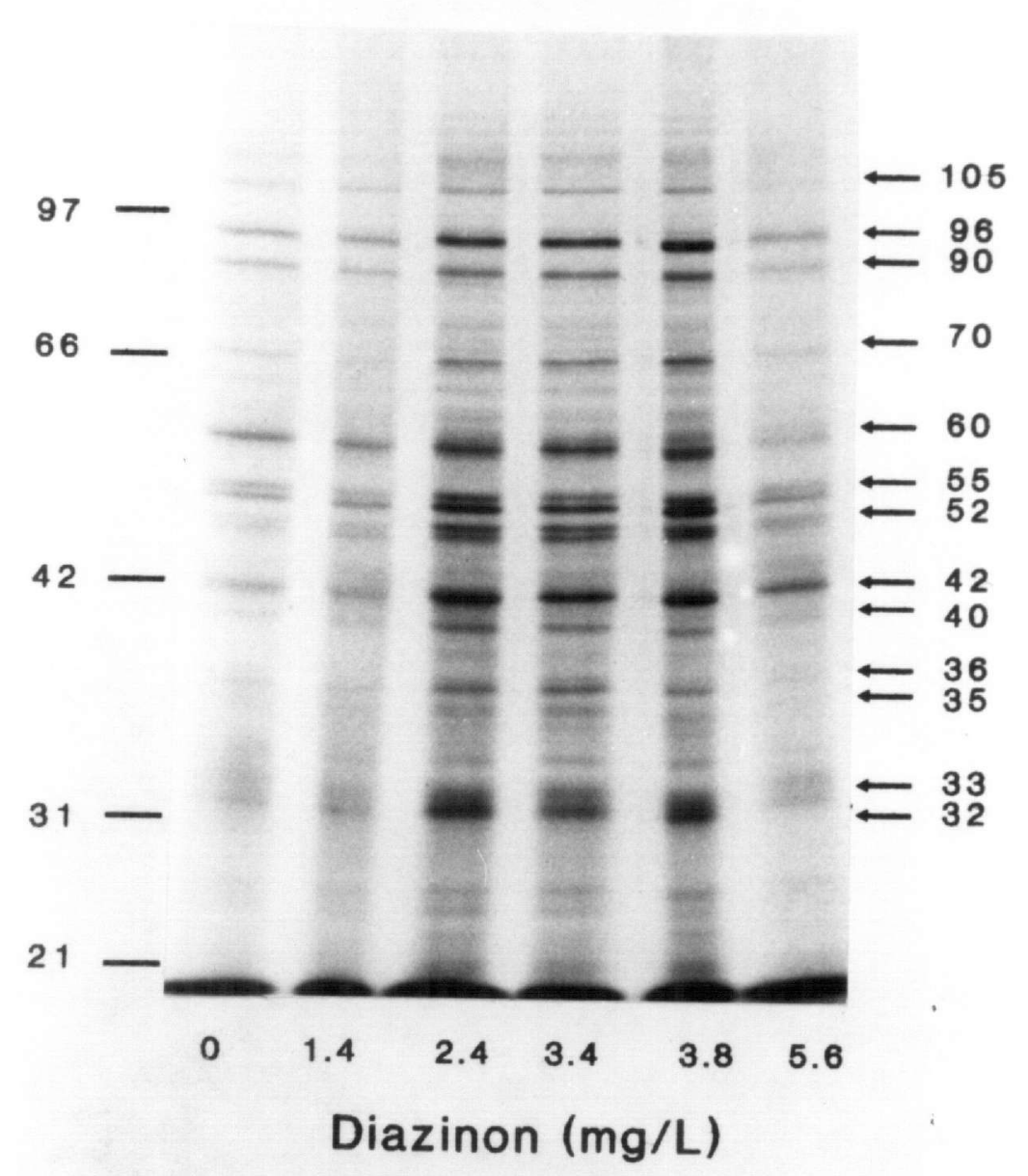

Figure 28. A fluorogram of brain tissue protein of fathead minnows exposed to 0 , $1.4,2.4,3.4,3.8$, and $5.6 \mathrm{mg}$ diazinon/L for $12 \mathrm{~h}$. Molecular weight markers are designated on the left. The arrows on the right denote proteins of $32,33,35,36$, $40,42,52,55,60,70,90,96,105 \mathrm{kD}$. 


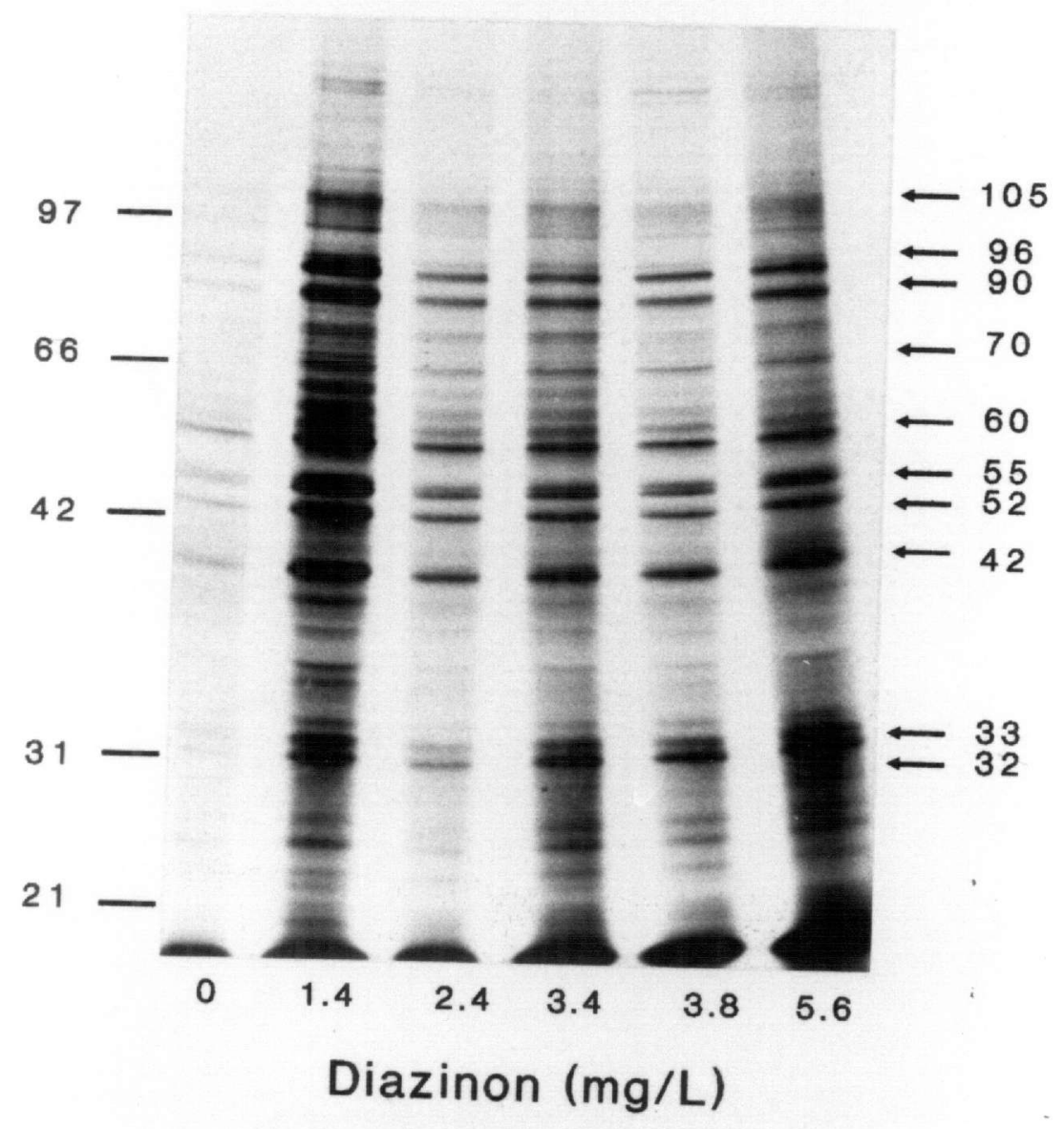

Figure 29. A fluorogram of brain tissue protein of fish exposed to a range of diazinon concentrations. Lanes were normalized to radioactivity $(150,000 \mathrm{cpm})$. Molecular weight markers are designated on the left. The arrows on the right denote proteins of $32,33,42,52,55,60,70,90,96$, and $105 \mathrm{kD}$. 
four replicates showed that diazinon did not significantly affect radiolabel incorporation into any of the observed proteins. Nevertheless, significantly increased incorporation rates above controls were found at 3.8 and $5.6 \mathrm{mg} / \mathrm{L}$ for the $32-\mathrm{kD}$ protein and $5.6 \mathrm{mg} / \mathrm{L}$ for stress protein 70 (Dunnett $\mathrm{T}$ test, $\mathrm{p} \leq 0.05$ ).

A strikingly different translation pattern was found in the brain (Fig. 28). Thirteen different proteins were observed with apparent molecular weights of 32 , $33,35,36,40,42,52,55,60,70,90,96$, and $105 \mathrm{kD}$. Radiolabel incorporation into all observed proteins increased above control levels at $2.4,3.4$, and $3.8 \mathrm{mg}$ diazinon/L. At $5.6 \mathrm{mg}$ diazinon $/ \mathrm{L}$, there was a decrease in label incorporation into seven $(32,33,35,36,40,70$, and $105 \mathrm{kD})$ out of the thirteen proteins . A similar translation pattern was seen in fluorograms from radioactivity-normalized gels. Ten proteins with molecular weights of $32,33,42,52,55,60,70,90,96$, and 105 $\mathrm{kD}$ were observed (Fig. 29). Incorporation of radiolabel into all observed proteins was least in control compared to levels in brains from fish exposed to a range of diazinon concentrations.

Radiolabel incorporation into only the $90 \mathrm{kD}$ protein was significantly affected by diazinon treatments (Kruskal-Wallis, $\mathrm{p}=0.05$; Table 2). However, at alpha $\leq 0.1$, synthesis and accumulation of four $(33,42,70,96 \mathrm{kD})$ other proteins were significantly affected. Dixon's outlier test revealed three data points (one for p90, two for p60) that could have compromised treatment significance. Outliers removed, probabilities of type II errors were decreased to 0.01 and 0.12 for the 90 and $60 \mathrm{kD}$ proteins, respectively. Dunnett's $\mathrm{T}$ tests performed on ranked data 


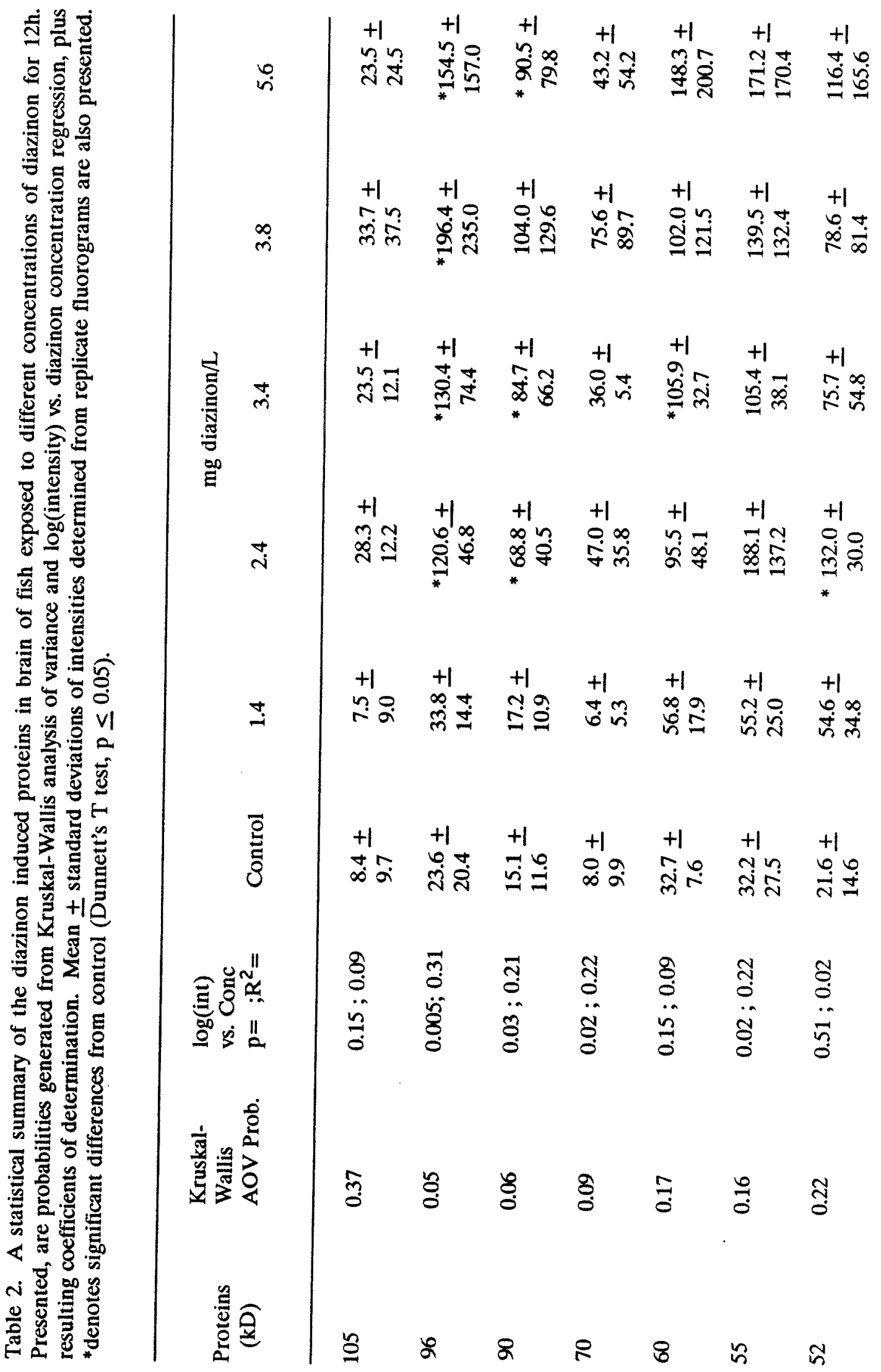




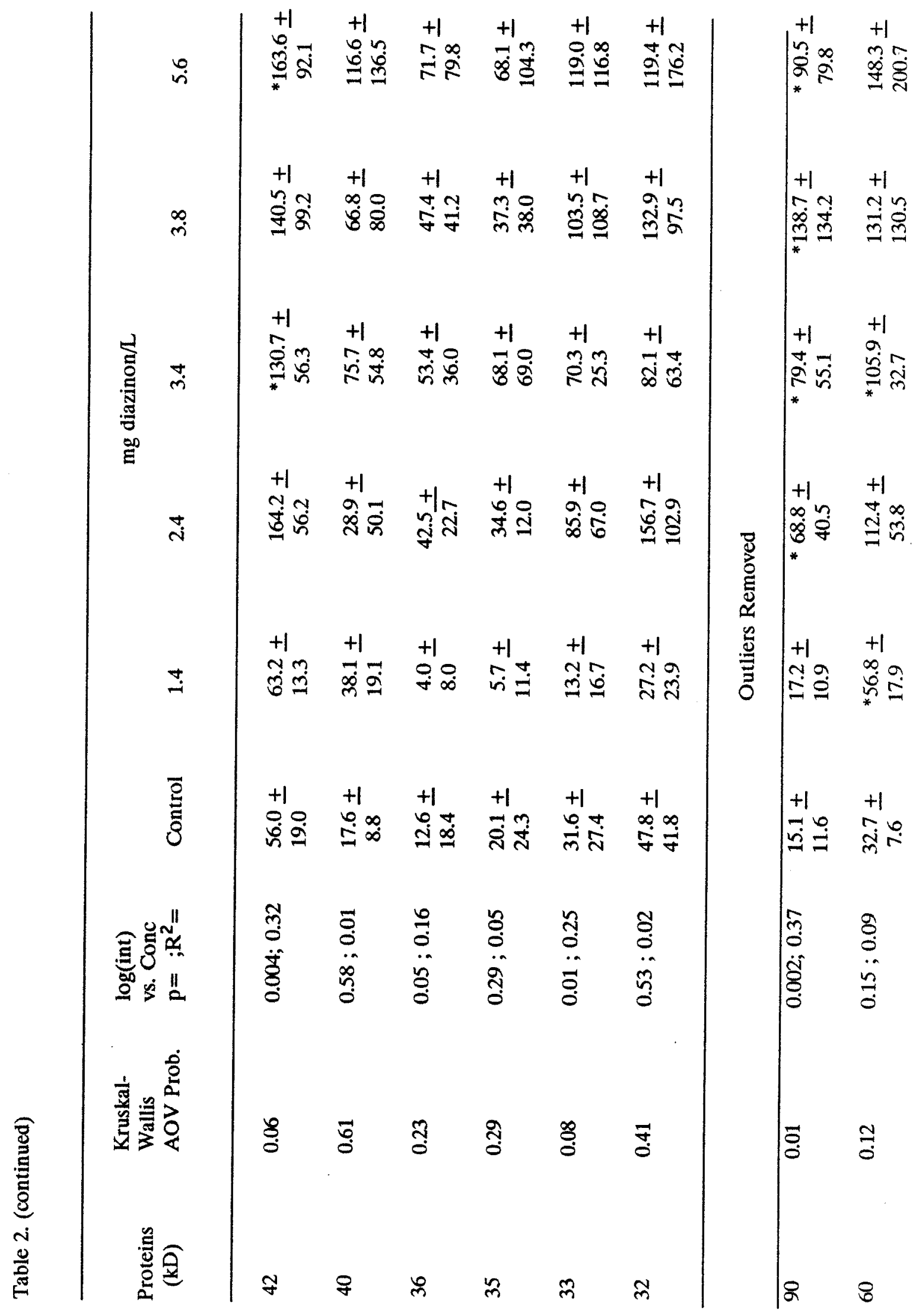




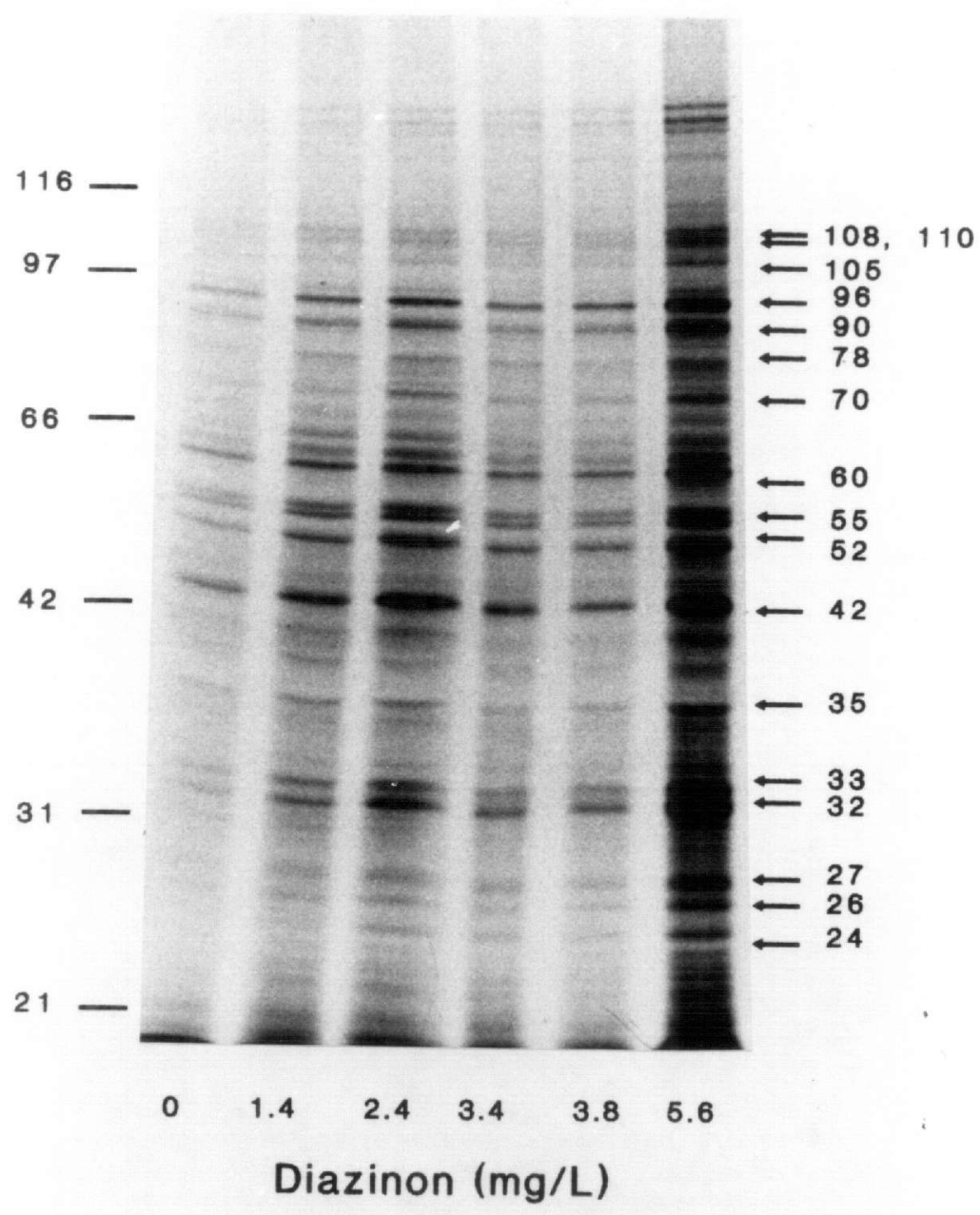

Figure 30. A fluorogram of striated muscle tissue protein of fathead minnows exposed to $0,1.4,2.4,3.4,3.8$, and $5.6 \mathrm{mg}$ diazinon/ $\mathrm{L}$ for $12 \mathrm{~h}$. Molecular weight markers are designated on the left. The arrows on the right denote proteins of $24,26,27,32,33,35,4252,5560,70,78,90,96,105,108$, and $110 \mathrm{kD}$. 


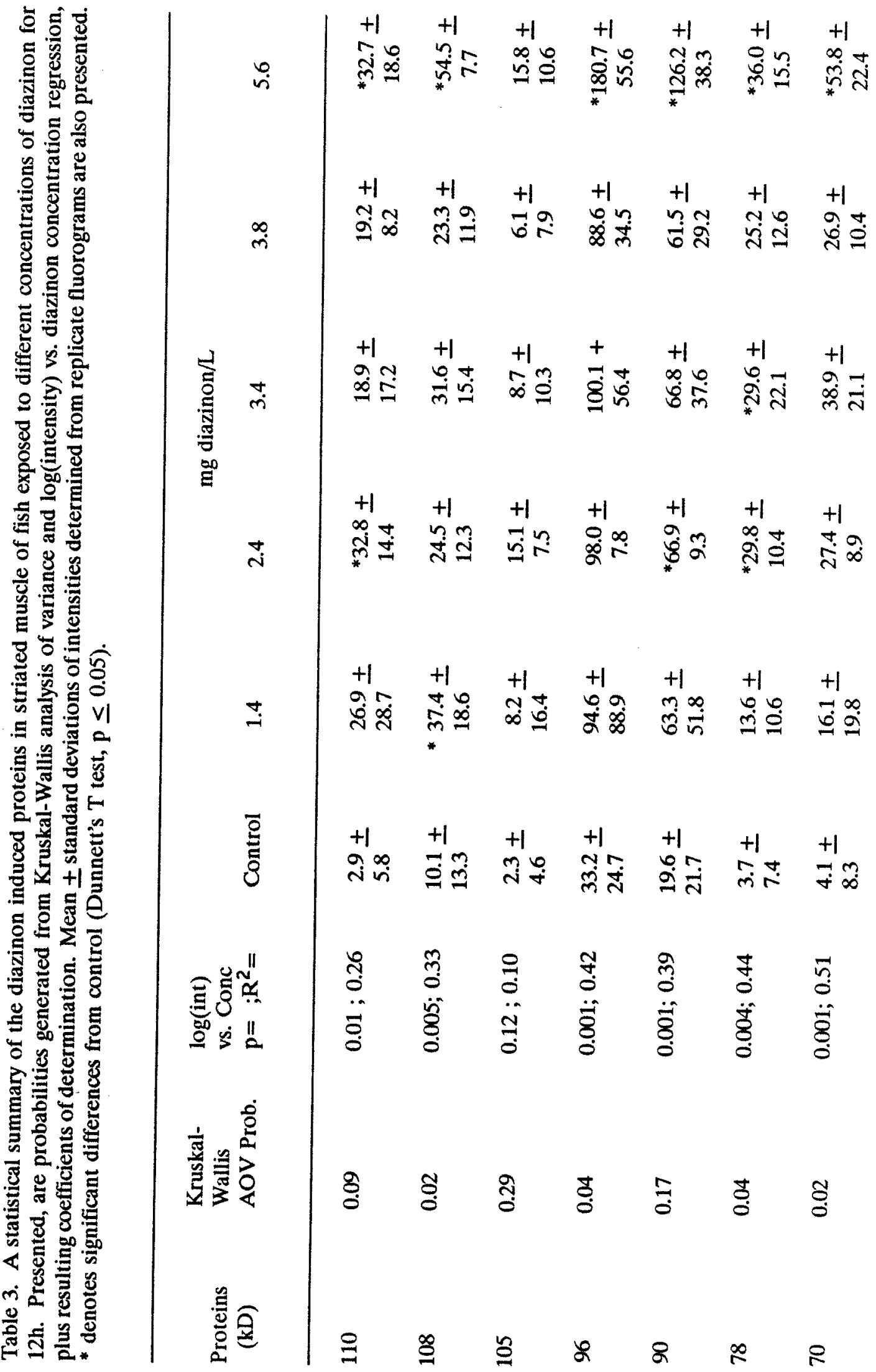




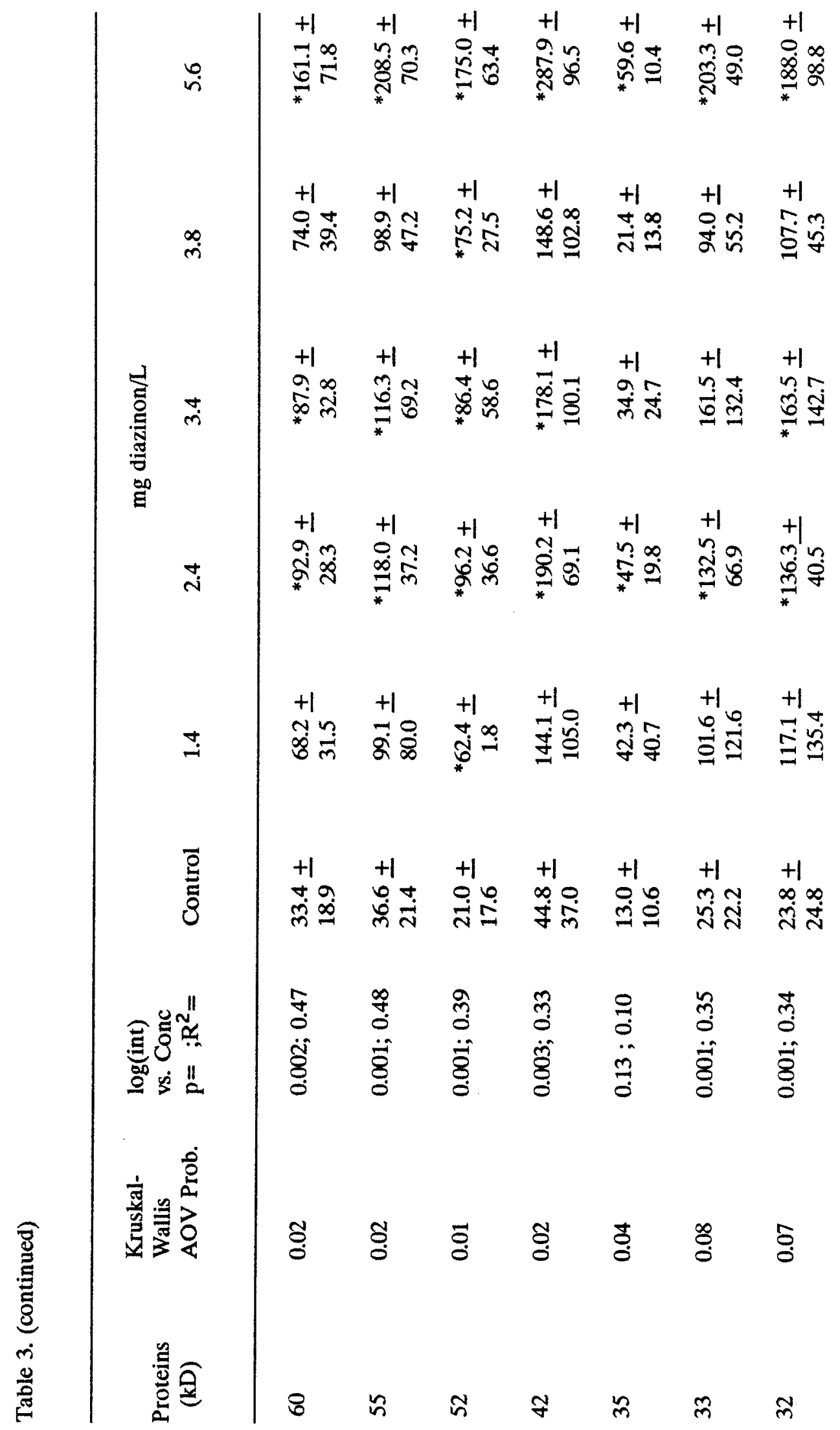




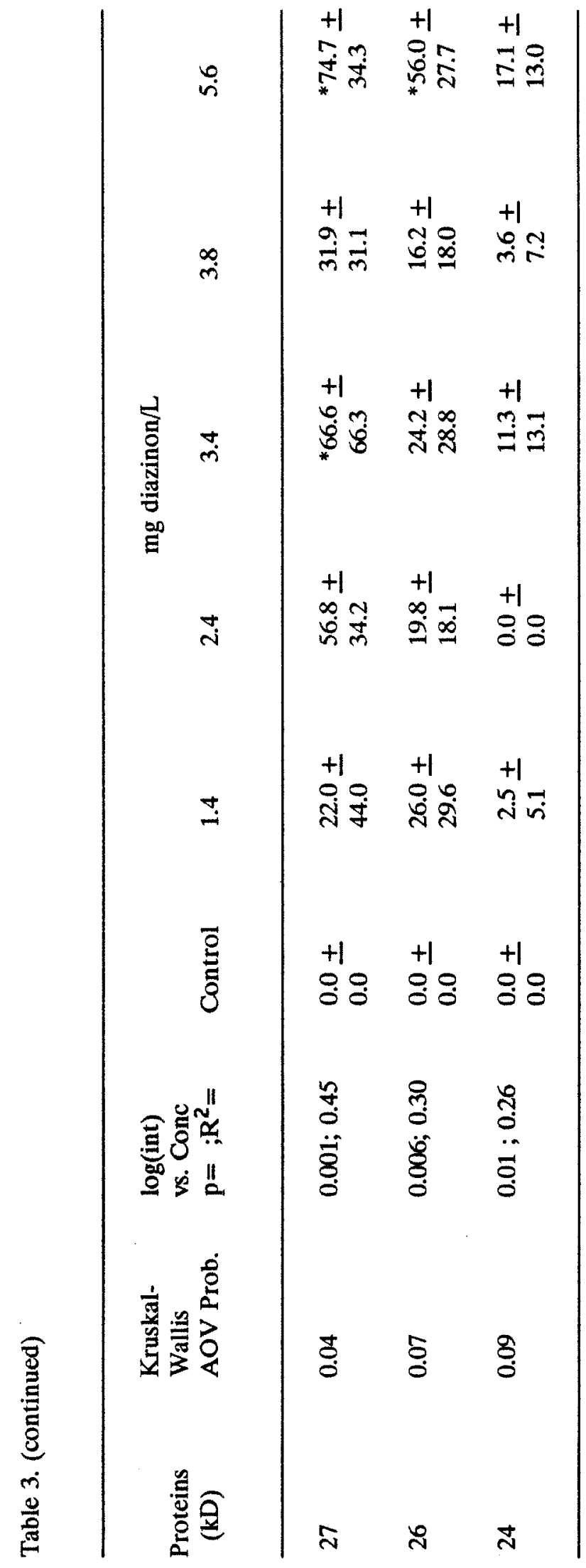


showed that incorporation significantly increased above controls at $2.4 \mathrm{mg}$ diazinon $/ \mathrm{L}$ for $42,52,60,90$, and $96 \mathrm{kD}$ proteins ( $\mathrm{p} \leq 0.05$ ). At $3.4 \mathrm{mg} / \mathrm{L}$, syntheses and accumulations of 60,90 , and $96 \mathrm{kD}$ proteins were significantly increased $(\mathrm{p} \leq 0.05)$. Ninety and $96 \mathrm{kD}$ protein syntheses were significantly greater than controls at $3.8 \mathrm{mg} / \mathrm{L}$. At the highest concentration, $5.6 \mathrm{mg} / \mathrm{L}$, radiolabel incorporation into four proteins $(42,55,90,96 \mathrm{kD})$ was significantly increased above controls.

Log transformed intensity values regressed against diazinon concentration revealed significant concentration responses for seven $(33,36,42,55,70,90$, and $96 \mathrm{kD})$ out of the thirteen quantitated proteins $(\mathrm{p} \leq 0.05)$. However, due to high data variability, coefficients of determination for the same proteins ranged from 0.16 to 0.37 . In addition, synthesis and accumulation was was not found to be significantly correlated to mortality for any of the observed proteins (Spearman rank correlation, $\mathrm{p} \leq 0.05)$.

Compared to responses in brain, a similar stress induced pattern was found in the striated muscle (Fig. 30). Seventeen different proteins were observed with apparent molecular weights of $24,26,27,32,33,35,42,52,55,60,70,78,90,96$, 105,108 , and $110 \mathrm{kD}$. All but the 24,26 , and $27 \mathrm{kD}$ proteins were observed in the controls. However, radiolabel incorporation into all observed stress induced proteins increased above controls at all diazinon concentrations.

Diazinon treatments significantly affected the incorporation of label into eleven out of the seventeen proteins quantitated in the striated muscle (Kruskal- 


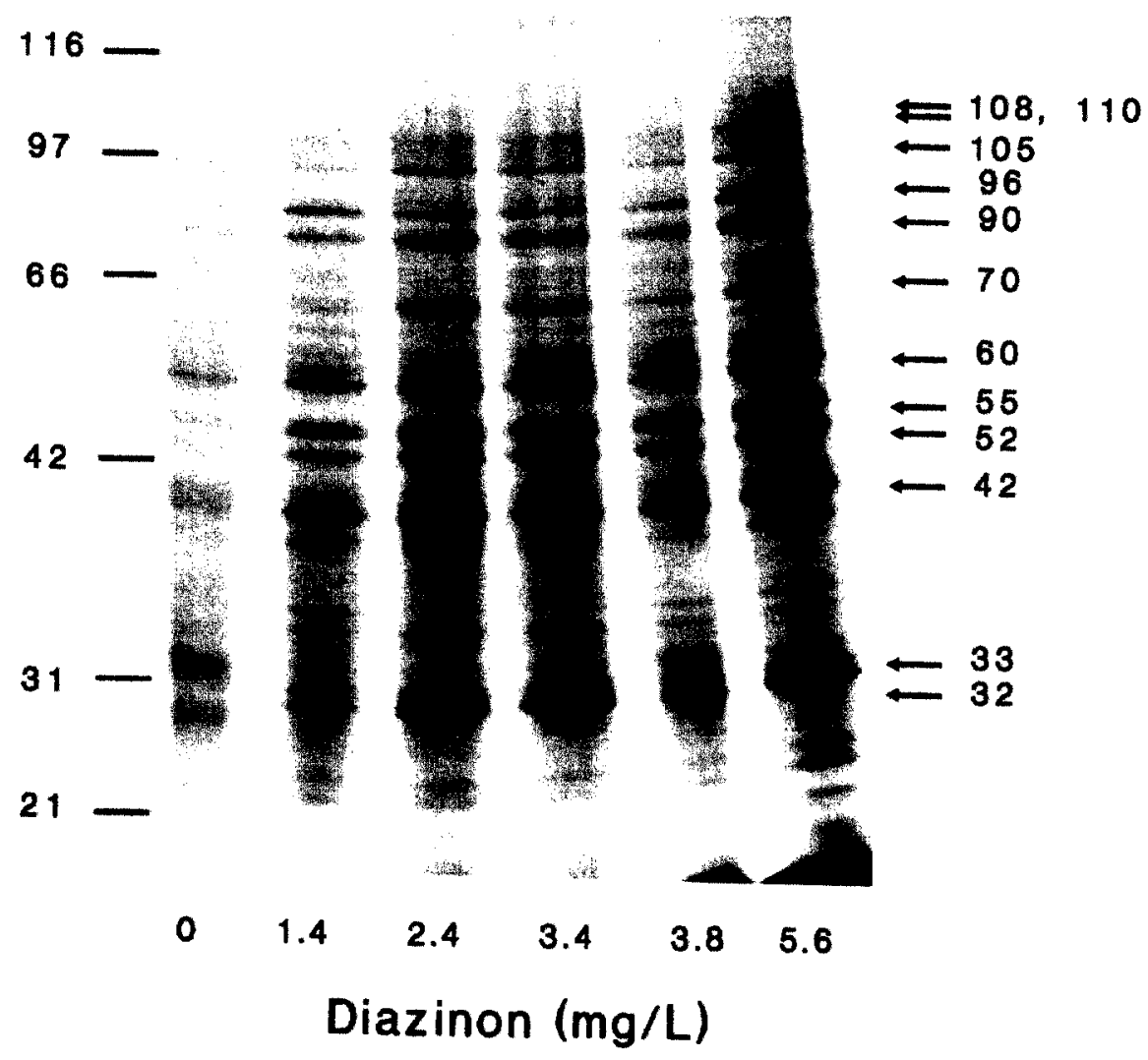

Figure 31. A fluorogram of striated muscle tissue protein of fish exposed to a range of diazinon concentrations. Lanes were normalized to radioactivity $(150,000$ $\mathrm{cpm})$. Molecular weight markers are designated on the left. The arrows on the right denote proteins of $32,42,52,55,60,70,90,96,105,108$, and $110 \mathrm{kD}$. 
Wallis, $\mathrm{p} \leq 0.05$; Table 3 ). Significantly altered incorporations were determined for proteins of $27,35,42,52,55,60,70,78,90,96$, and $108 \mathrm{kD}$. Dunnett's $\mathrm{T}$ tests performed on ranked data showed a significantly increased radiolabel incorporation into 52 and $108 \mathrm{kD}$ proteins at $1.4 \mathrm{mg} / \mathrm{L}$. At $2.4 \mathrm{mg} / \mathrm{L}$, eleven proteins $(27,32,33,35,42,52,55,60,78,90$, and $110 \mathrm{kD})$ were significantly induced. At $3.4 \mathrm{mg} / \mathrm{L}$, seven $(27,42,52,55,60,70$, and $78 \mathrm{kD})$ were induced. Large variability in the $3.8 \mathrm{mg} / \mathrm{L}$ replicates compromised significance such that only the $52-\mathrm{kD}$ protein showed a significantly increased incorporation rate. However, sixteen of the seventeen quantitated proteins showed significant increases in label incorporation at the highest concentration, $5.6 \mathrm{mg} / \mathrm{L}$. Fluorograms from gels normalized to radioactivity revealed preferential allocation of isotope into twelve proteins $(32,33,42,52,55,60,70,90,96,105,108$, and 110 $\mathrm{kD}$ ) of striated muscle from diazinon treated fish (Fig. 31). In all diazinon treatments, incorporation into each of these proteins was greater than observed in the controls.

\section{Discussion}

The acute exposure of fathead minnows to $8 \mathrm{mg} / \mathrm{L}$ resulted in the elicitation of the stress protein response in gill, brain and striated muscle tissues. By $12 \mathrm{~h}$, incorporation of ${ }^{35} \mathrm{~S}$-methionine/cysteine into stress proteins was maximum in all three tissues. However, the numbers and sizes of stress proteins induced were tissue specific. 
Markedly different translational patterns were observed in the gill, brain and striated muscle tissues of fish exposed to a range of diazinon concentrations. Striated muscle synthesized and accumulated the most stress induced proteins (seventeen), followed by brain (thirteen) and gill (five). In addition, concentrations required to induce the stress response were lower in the striated muscle and brain compared to gill. Statistically, diazinon did not induce the stress response in the gill whereas two out of thirteen in the brain and eleven out of the seventeen observed in the striated muscle were found to be significantly affected by diazinon treatments. Diazinon's mode of action may partially explain the dramatic tissue specific translational differences.

The classical definition of organophosphate insecticide mode of action is that they are acetylcholinesterase inhibitors (Matsumura, 1985). Inhibition of this enzyme results in the accumulation of acetylcholine at nerve endings. Organs are consequently effected, exhibiting signs and symptoms that mimic muscarinic, nicotinic, and central nervous system actions of acetylcholine (Murphy, 1986). Muscarinic effects are found primarily in smooth muscle, the heart, and exocrine glands (Durham, 1987; Murphy, 1986). Nicotinic effects occur primarily at neuromuscular junctions and antonomic ganglia (Murphy, 1986; Durham, 1987). Accumulation of acetylcholine in the central nervous system has been found to depress respiratory and circulatory centers (Murphy, 1986). In summary, toxicity of diazinon most likely involves respiratory distress (Murphy, 1986) caused by depression of CNS respiratory and circulatory centers in addition to bronchial 
constriction, increased lamellar secretions, and muscular fatigue (Smith, 1984) caused by overstimulation of the post synaptic neuromuscular junction.

Therefore, a plausible explanation for the lack of the stress response in gill might be due to respiratory failure. The increased stress responses in the brain and striated muscle tissues, on the other hand, could be due to overstimulation of neural and muscle cells.

In support of this explanation, Vijayalakshmi (1980) found that sumithion, an organophosphate insecticide, exposed fish resulted in greater inhibition of oxygen consumption and succinate dehydrogenase activity in the gill versus the striated muscle. In addition, expousure of Tilapia mossambica to organophosphate insecticides resulted in the inhibition of oxydative enzymes such as succinate dehydrogenase, lactate dehydrogenase, malate deydrogenase, and cytochrome coxidase in gill, brain, and striated muscle tissues (Rao and Rao, 1979; Basha et al., 1984). However, Rao and Rao (1979) also found total protein and free amino acids levels to significantly increase in muscle and gill of fish exposed to sublethal concentrations of methyl parathion. Recently, heme oxygenase (a $32 \mathrm{kD}$ stress protein) activity in hepatopancreas of the carp (Cyprinus carpio) has been shown to be markedly increased in diazinon treated fish (Ariyoshi et al., 1990).

The use of acetylcholinesterase inhibition as a biochemical indicator of organophosphate and carbamate insecticide exposure has been proposed (William and Sova, 1966; Coppage, 1972; Coppage et al., 1975; Coppage, 1977; Ansari and Kumar, 1984). Unfortunately, acetylcholinesterase inhibition has been shown to 
be markedly affected by season and temperature and is not significantly correlated to mortality (Thiruganonam and Forgash, 1975; Mayer, 1983). In addition, Olson and Christensen (1980) showed that fish acetylcholinesterase was inhibited 156 fold greater by arsenite compared to diazinon. Thus, use of this enzyme's inhibition as a biomarker of organophosphate exposure is controversial, to say the least.

This study, on the other hand, showed that a significant stress response occurred at concentrations at or below the LC1 in both brain and striated muscle. Therefore, the stress protein response has potential to serve as a biochemical indicator of organophosphate exposure. Furthermore, in comparing relative increases in gene expression, or lack thereof, between potential effector organs or tissues, it may be possible to delineate toxicant type(s). For example, previous studies we have performed clearly show that metal induced stress responses were most significant in gill versus striated muscle tissues of exposed fathead minnows. In accordance with these findings, the pattern of translation has also been shown to be toxicant specific. Unlike the lack of ability of acetylcholinesterase activity to distinguish arsenite versus organophosphate exposure, the tissue and toxicant specific translational patterns of the stress response may serve as a better diagnostic of toxicant specific stress. 


\title{
CHAPTER IV
}

\section{PRELIMINARY FIELD VALIDATION}

\author{
Introduction
}

Biological effects from toxicant exposure are manifest first at the molecular/cellular level and then proceeds through increasing levels of biological organization (i.e. organism, population, community, etc). Thus, use of biochemical parameters to assess biotic stress has the potential to be more sensitive than higher order indicators and may indeed serve as an early warning of impending doom for higher levels of organization.

Several studies performed in the laboratory with fathead minnows have shown that stress protein 70 is induced under a variety of exposures, such as heat shock, sodium arsenite, sodium chromate, lindane, and diazinon. The sum of these studies advocates the potential use of stress protein 70 as a general stress indicator. In particular, quantitative methods using immunological techniques have proven to be highly sensitive, especially in gill tissue.

To test the efficacy of stress protein 70 induction as a potential biomonitoring tool, we performed a preliminary field assessment by exposing laboratory reared fish in cages to an acute to chronic toxicity gradient. This study was conducted in Soldier Creek, Midwest City, Oklahoma. Soldier Creek orginates as an industrial effluent from Tinker Air Force Base. The creek flows 
approximately five miles north-northwest before its confluence with Crutcho Creek. Crutcho Creek flows approximately another 2 miles until its confluence with the North Canadian River.

Historically, Soldier Creek has been shown to be acutely toxic throughout its entire length and contain few fish (Simpson et al., 1987; Ontech, Inc. and Trac Laboratory, Inc., 1987). However, reconnaisance visits during the summers of 1989 and 1990 revealed viable fish communities in the middle and lower reaches of the creek, whereas the upper reach, toward Tinker Air Force Base, contained little or no fish. Thus, there has been an acute-chronic toxicity gradient within the creek. The purpose of this study was to compare the induction of stress protein 70 to percent mortality and in situ fish species richness.

\section{Materials and Methods}

Ninety- to 120-day-old fathead minnows (Pimphales promelas) were obtained from a culture located at the University of North Texas. Fish used for the study were acclimated to $25^{\circ} \mathrm{C}$ for at least 7 days and a $16 \mathrm{~L}: 8 \mathrm{D}$ photoperiod and were fed frozen brine shrimp twice daily to satiation.

Cages consist of 12 inch long, 6 inch diameter heavy PVC pipe with 40-52 one inch diameter holes drilled over the pipe length. Fiberglass window screen was wrapped around the outside of the pipe and fitted with adhesive tape and 6 inch stainless steel ring clamps. 
Three to four fathead minnows were placed into each cage. One cage each was placed at six different sites along Soldier Creek and one in the North Canadian River (Figure 32). Fish were exposed 4d, from 7/3/90 through 7/6/90. After the exposure period, fish were sacrificed, wrapped in aluminum foil, and then placed in liquid nitrogen. Gill tissue destined for stress protein 70 analysis was dissected in our laboratory.

Fish were collected from all Soldier Creek and North Canadian River stations on $9 / 14 / 90$. Three, ten meter seine hauls using a twenty foot quarter-inch mesh seine, were conducted at each site.

Protein from gill tissue of caged fish was assayed for stress protein levels using the methodology (quantitative immunoblots) described in the chromate and lindane experiments. Gill protein from non-exposed cultured fish was used as a performance control.

A Spearman Rank Correlation was used to assess the significance of the relationship between minimum detection levels for stress protein 70 and species richness.

\section{Results}

Proceeding from upstream to downstream, toxicity (percent mortality) decreased while in situ fish numbers and species richness increased (Table 4; Fig. 33). From sites 3 through 6 of Soldier Creek and the North Canadian River site, 


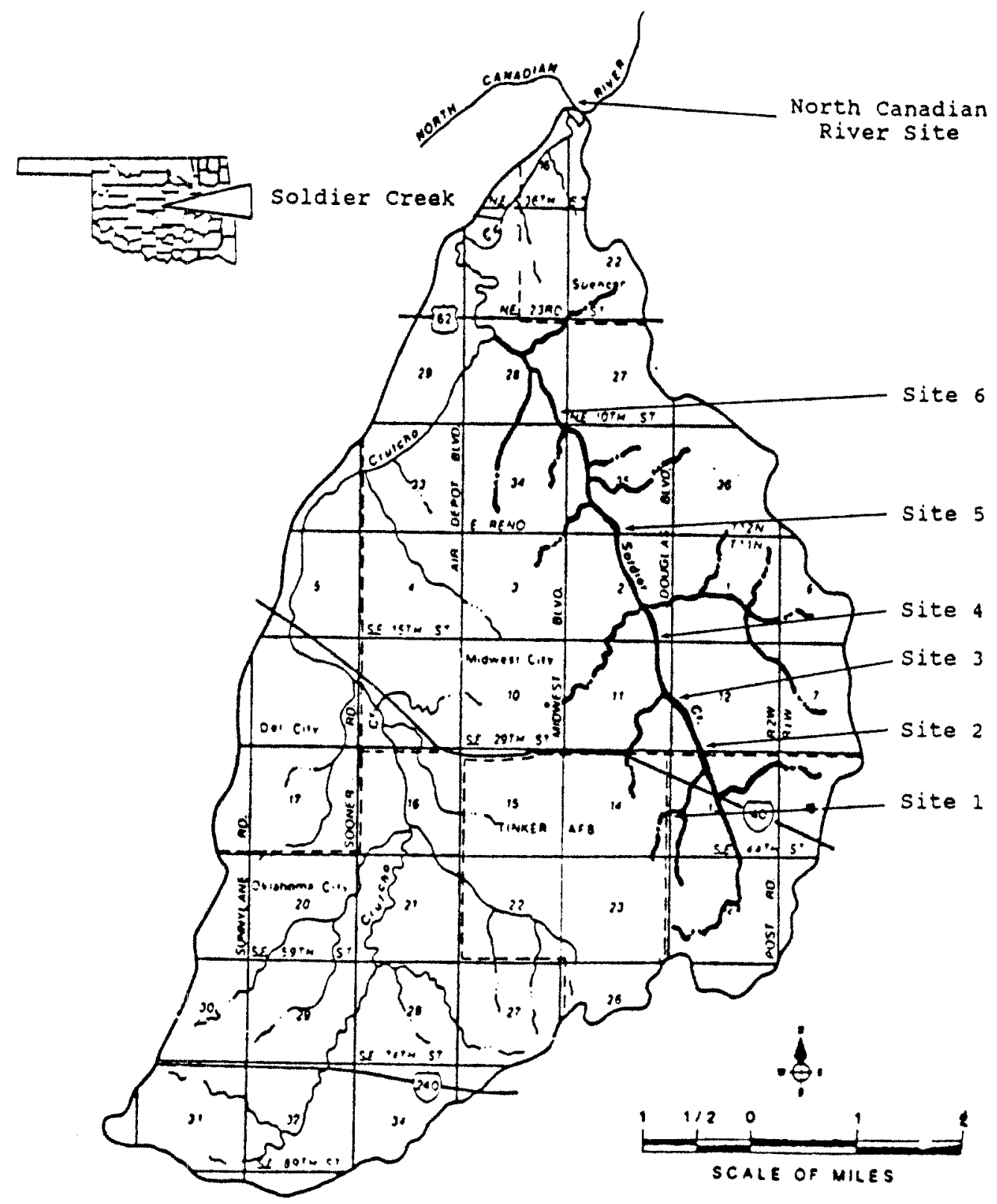

Figure 32. Locations of fish cages and in situ fish collection sites on Soldier Creek and North Canadian River during 7/90 and 9/90. 
Table 4. Minimum detection levels for stress protein 70 and percent mortality of caged fish, in situ species richness, and numbers of individuals collected in Soldier Creek and North Canadian River, by site.

\begin{tabular}{|c|c|c|c|c|}
\hline Site & $\begin{array}{l}\text { sp } 70 \\
\text { Level }\end{array}$ & $\begin{array}{l}\text { Percent } \\
\text { Mortality }\end{array}$ & Species & $\begin{array}{l}\text { Numbers of } \\
\text { Individuals }\end{array}$ \\
\hline 1 & NA & 100 & fathead minnow (Pimephales promelas) & 1 \\
\hline 2 & $\mathrm{NA}$ & 100 & red shiner (Notropis lutrensis) & 6 \\
\hline 3 & 3.125 & 0 & $\begin{array}{l}\text { mosquitofish (Gambusia affinis) } \\
\text { red shiner (Notropis lutrensis) } \\
\text { fathead minnow (Pimephales promelas) } \\
\text { redfin shiner (Notropis umbratilis) }\end{array}$ & $\begin{array}{c}330 \\
21 \\
3 \\
2\end{array}$ \\
\hline 4 & 3.125 & 0 & $\begin{array}{l}\text { red shiner (Notropis lutrensis) } \\
\text { mosquitofish (Gambusia affinis) }\end{array}$ & $\begin{array}{c}105 \\
12\end{array}$ \\
\hline 5 & 3.125 & 0 & $\begin{array}{l}\text { red shiner (Notropis lutrensis) } \\
\text { mosquitofish (Gambusia affinis) } \\
\text { green sunfish (Lepomis cyanellus) }\end{array}$ & $\begin{array}{c}374 \\
92 \\
13\end{array}$ \\
\hline 6 & 3.125 & 0 & $\begin{array}{l}\text { red shiner (Notropis lutrensis) } \\
\text { mosquitofish (Gambusia affinis) } \\
\text { fathead minnow (Pimephales promelas) } \\
\text { green sunfish (Lepomis cyanellus) } \\
\text { sand shiner (Notropis stramineus) } \\
\text { bigmouth shiner (Notropis dorsalis) } \\
\text { suckermouth minnow (Phenacobius } \\
\text { mirabilis) } \\
\text { common carp (Cyprinus carpio) }\end{array}$ & $\begin{array}{c}716 \\
384 \\
81 \\
43 \\
38 \\
19 \\
1 \\
1\end{array}$ \\
\hline $\begin{array}{l}\text { No. } \\
\text { Can. } \\
\text { Riv. }\end{array}$ & 6.250 & 0 & $\begin{array}{l}\text { red shiner (Notropis lutrensis) } \\
\text { mosquitofish (Gambusia affinis) } \\
\text { bullhead minnow (Pimephales vigilax) } \\
\text { fathead minnow (Pimephales promelas) } \\
\text { green sunfish (Lepomis cyanellus) } \\
\text { bigmouth shiner (Notropis dorsalis) } \\
\text { river carpsucker (Carpiodes carpio) } \\
\text { gizzard shad (Dorosoma cepedianum) }\end{array}$ & $\begin{array}{c}1867 \\
99 \\
49 \\
4 \\
2 \\
1 \\
1 \\
1\end{array}$ \\
\hline
\end{tabular}

NA = Not applicable since no fish tissue was available 
caged fish stress protein minimum detection levels were highly significantly correlated to in situ fish species richness (Spearman rank correlation, $r=0.95, \mathrm{p}$ $\leq$ 0.001). Minimum detection levels of stress protein 70 in North Canadian River fish (6.25 ug total protein) was the same as that found in reference controls.

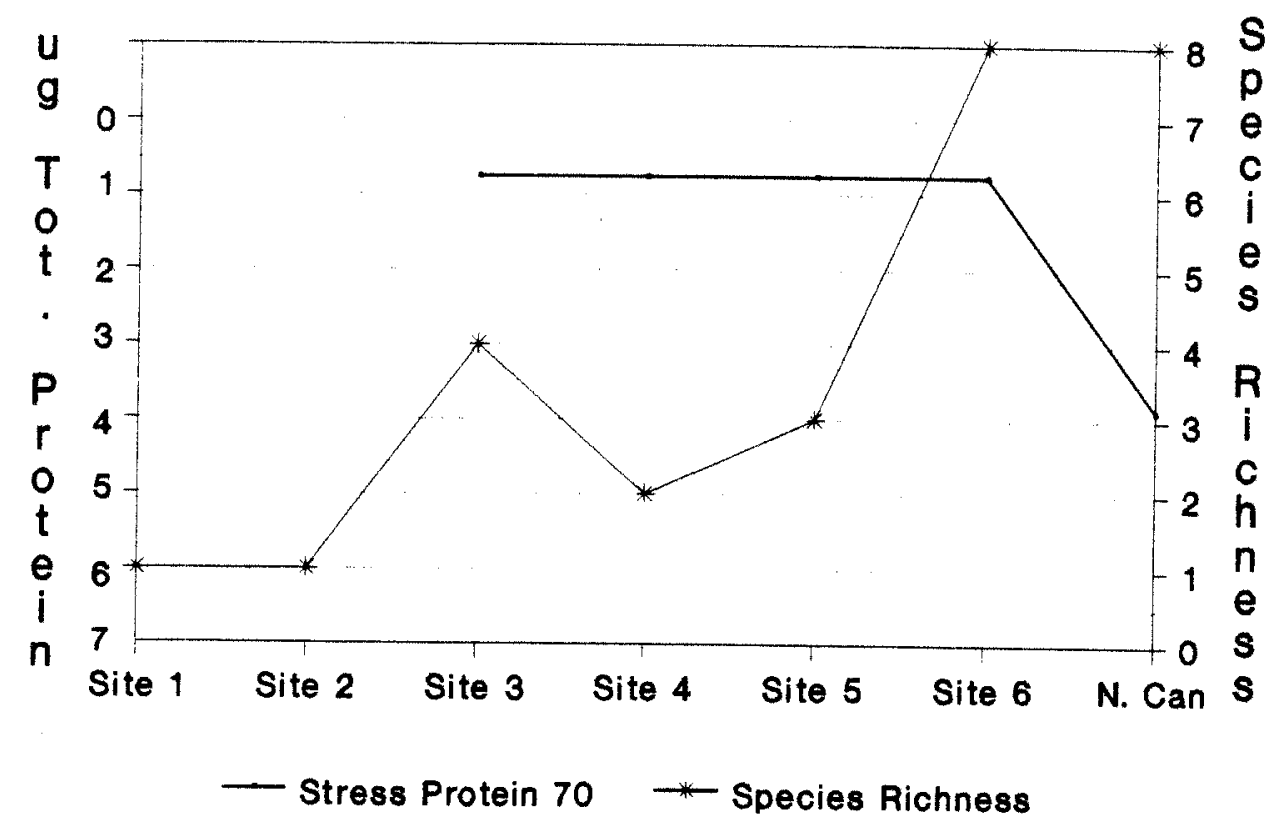

Figure 33. Line diagram that illustrates the relationships between accumulation of stress protein 70 in gill tissue of caged fish and in situ fish species richness to site location. 


\section{Discussion}

This preliminary test indicated that use of stress protein 70 as a general indicator of stress has applicability. Continued field research coupled with extensive water chemistry and in situ biotic assessments is required to fully evaluate the efficacy of the stress proteins as a biomonitoring tool. Moreover, investigations using antibodies to other stress proteins, such as stress proteins 20 , 60 , and 90, are warranted since previous studies in our laboratory have indicated the positive potential of teasing out chemicals or classes of chemicals responsible for biotic aberrations observed in the environment. 


\section{CHAPTER V}

\section{GENERAL OVERVIEW AND CONCLUSIONS}

The objective of this research endeavor was to evaluate the phenotypic expression of the stress proteins as a biochemical water quality biomonitoring method. The approach used for assessing the stress protein response (SPR) as a potential biomonitoring tool consisted of laboratory and in situ (field) exposures. To accomplish the proposed objective, the SPR was characterized in fathead minnows (Pimephales promelas), via laboratory experiments, by exposing fish to a variety of stressors, including chemicals with different modes of action. The goal of the laboratory studies was to determine relationships between the types and concentrations of stressors and the SPR in selected tissues. In these studies I: 1) identified stress protein patterns in gill, brain and striated muscle of fathead minnows; 2) compared stress responses elicited by a variety of stressors (heat shock, sodium arsenite, sodium chromate, lindane, and diazinon); and 3) correlated (calibrated) the stress responses to conventional toxicity endpoints, such as effects on survival.

Secondly, attempts to validate the SPR as a potential biomonitoring tool were accomplished by: 1) exposing caged laboratory raised fathead minnows in situ to an acute-chronic toxicity gradient; 2) evaluating the SPR in gill tissue of fish placed at selected locations in relation to the toxicity gradient; and 3) correlating 
the SPR to in situ fish species richness.

In the next few pages the salient features and conclusions based on the performed research are presented.

\section{The Stress Protein Response Is Rapid}

By and large, time to induction of the stress response is a rapid phenomenon. Striated muscle of fathead minnows exposed to $34^{\circ} \mathrm{C}$ elicited the SPR by $0.5 \mathrm{~h}$. Gill of fish exposed to $25 \mathrm{mg}$ As/L elicited the stress response by $2 \mathrm{~h}$ and reached maximum rates of radiolabel incorporation by $8 \mathrm{~h}$. Slightly slower minimum times to induction were found in gill of fathead minnows exposed to acutely toxic concentrations of chromate, lindane, and diazinon. For all three chemicals, the stress responses were elicited within 8 to $12 \mathrm{~h}$. Such findings are common in the literature. For example, cultured chinook salmon cells have been shown to elicit the SPR by $0.5 \mathrm{~h}$ of heat stress (Gedamu et al., 1983). Similarly, cultured HeLa, mouse fibroblast, and Neurospora crassa cells have elicited the SPR between 0.5 and $2 \mathrm{~h}$ exposure to arsenite (Hiwasa and Sakiyama, 1986; Duncan and Hershey, 1987; Kapoor and Lewis, 1987). In addition, syntheses of stress proteins in mouse fibroblasts have been shown to be induced by $0.2 \mathrm{mM}$ $\mathrm{K}_{2} \mathrm{CrO}_{4}$ with 2-h exposure (Hiwasa and Sakiyama, 1986). 


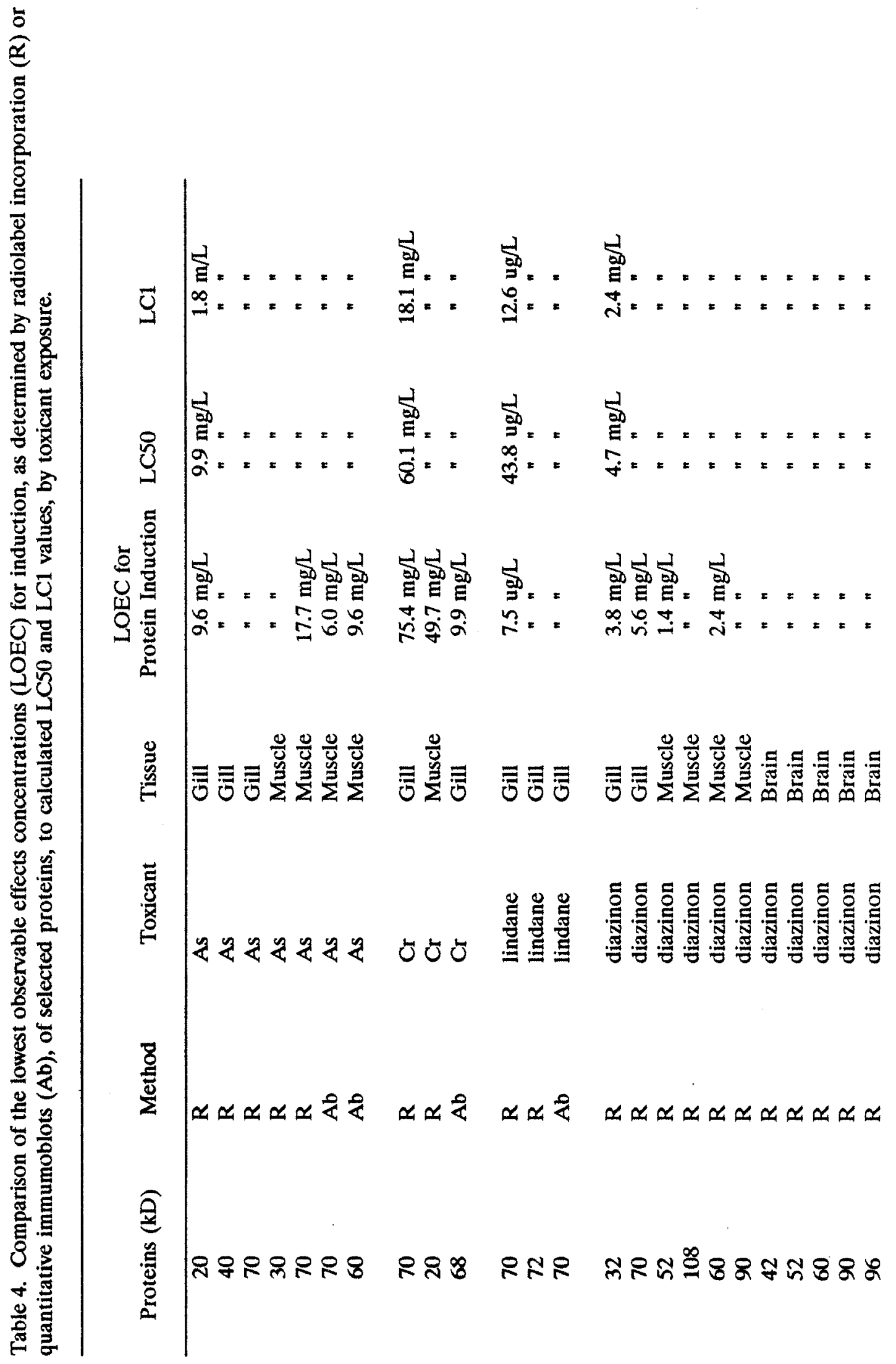


Sensitive and Environmentally Relevant

Induction of the stress response in gill, brain and striated muscle tissues of fathead minnows was found to be a sensitive response. Significantly increased radiolabel incorporation into proteins was documented at sublethal temperaturesand at concentrations near or below the LC1 in all three tissues (Table 5). In addition, accumulation of stress proteins (sp60 and sp70) using a quantitative immunological technique consistently revealed LOEC's (lowest observable effect concentrations) near or below the LC1. Moreover, both syntheses and accumulations of stress induced proteins were significantly correlated to toxicant concentration and percent mortality. Similar results were also evident in the field study where it was found that accumulations of $\operatorname{sp} 70$ were elevated only in fish exposed in Soldier Creek, compared to those in the reference (North Canadian River) site and performance controls. In addition, faunal fish species richness was significantly correlated to sp70 accumulation.

Similarly, accumulations of sp60 in mantle tissue of copper exposed Mytilus edulis have been reported to be an order of magnitude more sensitive than scopefor-growth, a sublethal whole organism index of health (Sanders et al., in press). Thus, current evidence supports the conclusion that the stress response is sensitive and at environmentally relevant concentrations. 
TRANSLATION PATTERNS IN GILL

\begin{tabular}{cccccc}
$\begin{array}{c}\text { PROTEINS } \\
\text { (KD) }\end{array}$ & HS & As & Cr & Lindane & Diazinon \\
\hline 20 & & + & + & & \\
30 & & + & + & & \\
32 & & + & + & & + \\
40 & & + & & & \\
60 & + & & & & \\
68 & + & & & & + \\
70 & + & + & + & + & + \\
72 & & + & & + & + \\
74 & & + & & & + \\
78 & + & & & & + \\
90 & + & & & & + \\
96 & & & & & + \\
100 & + & & & & \\
\hline
\end{tabular}

Figure 34. Translation patterns observed in gill tissue of fathead minnows exposed to five different stressors: heat shock, arsenite, chromate, lindane, and diazinon.

Potential Indicators of General and Stressor Specific Exposure

Incorporation of ${ }^{35} \mathrm{~S}$-methionine/cysteine into gill, brain and striated muscle tissue proteins from fish exposed to different stressors has yielded tissue and stressor specific translational patterns (Figs. 34, 35, and 36). In gill, from fish exposed to five different stressors, five different suites of proteins were elicited in each sampled tissue (Fig. 34). Six proteins (63, 68, 70, 78, 90, and $100 \mathrm{kD}$ ) were observed in heat shocked samples. However, a different array of six proteins (20, $30,40,70,72,74 \mathrm{kD}$ ) were found to be induced via arsenite exposure. Three 
TRANSLATION PATTERNS IN MUSCLE

\begin{tabular}{cccccc}
$\begin{array}{c}\text { PROTEINS } \\
(\mathrm{KD})\end{array}$ & HS & As & Cr & Lindane & Diazinon \\
\hline 20 & & + & + & & \\
$24,26,27$ & & & & & + \\
30 & & + & + & & + \\
32 & & & & & + \\
33 & & & & & + \\
35 & & & & & + \\
42 & & & & & + \\
52 & & & & & + \\
55 & & & & & + \\
60 & & & & & + \\
68 & & + & & & + \\
70 & + & + & + & + & + \\
78 & + & + & & & + \\
90 & + & + & & & + \\
96 & & & & & + \\
100 & + & & & & + \\
105 & & & & & + \\
108,110 & & & & & + \\
\hline
\end{tabular}

Figure 35. Translation patterns observed in striated muscle tissue of fish exposed to five different stressors: heat shock, arsenite, chromate, lindane, and diazinon.

proteins $(20,30,70 \mathrm{kD})$ were observed in fluorograms of gill tissue from minnows exposed to chromate. Only two proteins (70 and $72 \mathrm{kD}$ ) were observed from lindane exposures. Five proteins $(32,70,78,90,96 \mathrm{kD})$ were observed in gill of diazinon treated fish.

Similar patterns were observed in striated muscle (Fig. 35). Briefly, heat shock elicited four proteins $(70,78,90,100 \mathrm{kD})$; arsenite induced five $(20,30,40$, $68,70 \mathrm{kD})$; and chromate induced the elicitation of three $(20,30,70 \mathrm{kD})$ proteins. 


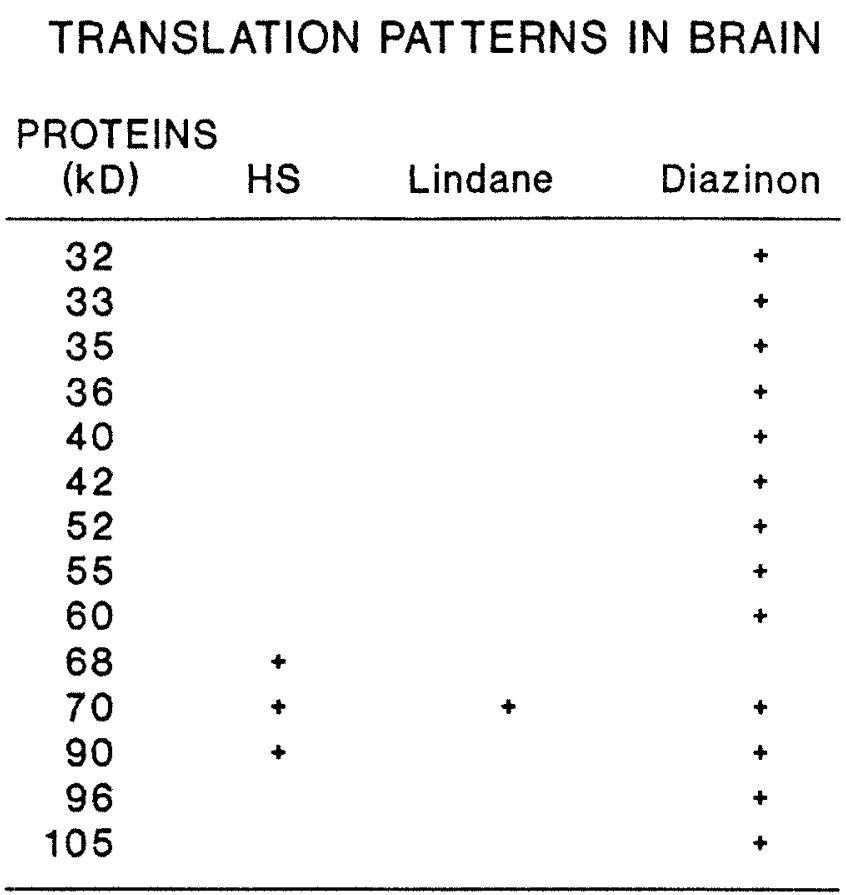

Figure 36. Translation patterns observed in brain of fathead minnows exposed to heat shock, lindane, and diazinon.

The two insecticide exposures yielded dramatically different patterns. Muscle of lindane exposed fish elicited one $(70 \mathrm{kD})$ protein, whereas samples from diazinon treated fish showed seventeen $(24,26,27,32,33,35,42,52,55,60,70,78,90,105$, $108,110 \mathrm{kD}$ ) being observed.

Patterns elicited by the brain were most similar to striated muscle tissue responses (Fig. 36). Increases in three stress proteins $(68,70,90 \mathrm{kD})$ were observed in heat shocked samples. A $70 \mathrm{kD}$ protein was elicited via lindane 
exposures. In contrast, thirteen $(32,33,35,36,40,42,52,55,60,70,90,96,110$ $\mathrm{kD}$ ) proteins were observed in brain from fish exposed to a range of diazinon concentrations.

Although the translation patterns show tissue and toxicant-specific responses all is not chaos, for three pieces of information can be extracted, each with profound implications. First, all three tissues from fish exposed to stressors with different modes of action elicited a $70 \mathrm{kD}$ protein. This finding was not surprising. Several reviews have clearly shown that this protein is induced by a wide variety of physical, chemical, and biological stressors, such as heat shock, metals, phenols, viruses, and parasites (Nover, 1984; Lindquist, 1986; Schlesinger, 1990). Thus, it is quite conceivable that induction of this protein can serve as an indicator of general stress. In fact, this particular aspect of the stress response has been incorporated previously into a multi-tiered biomarker approach in which sp70 is the foundation, a Tier I or general stress indicator (Jenkins and Sanders, 1986; Sanders, 1990).

Second, increased label incorporation into proteins of 20 and $30 \mathrm{kD}$ in both muscle and gill tissues were evident only in the metal exposed fish. Thus, these low molecular weight proteins may be indicative of metal exposure. Similarly, a study with rainbow trout (Oncorhynchus mykiss) cells showed that a $30 \mathrm{kD}$ protein was induced via arsenite exposure (Kothary and Candido, 1982). In addition, Hiwasa and Sakiyama (1986) found that a $32 \mathrm{kD}$ stress protein in mouse fibroblasts was induced by both arsenite and chromate. Interestingly, a $32 \mathrm{kD}$ 
stress protein known to be induced by arsenite and chromate, as well as other metals, has been identified as heme oxygenase (Shibahara et al., 1987; Keyse and Tyrell, 1989). Whether or not the $30 \mathrm{kD}$ protein found in fish is heme oxygenase circumstantial evidence lends their suspect. Even so, this system indicates sp30 to be indicative of metal induced stress.

Inducement of a $20 \mathrm{kD}$ protein via metal exposures has not been documented. However, Drosophila cells exposed to nickel and zinc were shown to elicit only two stress proteins, 22 and $23 \mathrm{kD}$ (Bournia-Vardiabasis, 1990). In addition, several studies with heat shock have shown proteins in the 20 to $27-\mathrm{kD}$ range to be induced (Kim et al., 1984; Duband et al., 1986; Duncan and Hershey, 1987; Arrigo, 1987; Merz and Laudien, 1987;). On the other hand, stress proteins below $63 \mathrm{kD}$ in fathead minnows were not observed in gill, brain, or striated muscle tissues from either in vivo or in vitro heat shock exposures.

Third, within each stressor exposure there was tissue specific expression of proteins. Tissue specificities were manifested in both total numbers of proteins as well as types elicited. Although most stress protein literature has been confined to simple in vitro systems, a few in vivo multi-tissue studies have been conducted. A study on lungless salamanders, Eurycea bislineata and Desmognathus ochrophaeus, showed discordant expression of heat shock proteins 30 and 70 between brain, stomach, and skin (Rutledge, et al., 1987). Tissue specific syntheses of hsp 70 and 72 mRNA's were also observed in rat brain, liver, lung, and skin (Blake et al., 1990). In addition, differential expression of proteins was observed in fat bodies 
and nerve cords of in vivo heat shocked cockroaches, Periplaneta americana (Ruder et al., 1989).

Gill of fathead minnows exposed to heat, arsenite, chromate, and lindane elicited the greatest numbers of stress-induced proteins and had the greatest incorporation of ${ }^{35} \mathrm{~S}$-methionine/cysteine. The response was lower in striated muscle and still lower in brain. However, generalities stop with fish exposed to diazinon. Here, greatest numbers of proteins elicited, as well as intensity of the response, occurred in the striated muscle, followed by brain, and then gill. This apparent disparity actually may be indicative of route of exposure and mode-ofaction. For instance, heat shock, arsenite, and chromate are known denaturers of proteins. Several investigations have clearly shown that, at least for sp70, denatured proteins serve as a signal for the stress response (Ananthan et al., 1986; Munro and Pelham, 1986; Beckmann et al., 1990). Compared to striated muscle and brain, gill has been shown to elicit more numbers of stress proteins with greater intensity. Here, route of exposure may partially explain the differences. Gill is the only organ system sampled that is exposed directly to the stressor, whereas muscle and brain require diffusion or are dependent on the circulatory system for stressor exposure. However, in the case of diazinon, a neurotoxicant, gill elicited the fewest proteins compared to brain and muscle and had the lowest levels of radiolabel incorporation compared to controls. Obviously, route of exposure cannot explain the disparity of responses, but instead mode of action most probably controls the response. 
Target tissues of a cholinesterase inhibitor are brain and muscle tissues. Gill has relatively little muscle tissue or innervation. Thus, the lack of response in the gill corresponds well with its anatomical differences, compared to the other two tissues. By examining the suites of proteins elicited, the intensity of response, and the tissue specificity, probable cause(s) of the stress response may be elucidated. Potential use of this phenomenon is tremendous. For instance, at the present time causes of toxicity within environmental matrices such as effluents and ambient water are determined through laborious fractionation techniques.

Chemical and toxicological properties of these fractions govern decisions made on probable cause(s) of toxicity. Potentially, stress responses evaluated in target tissues may provide similar types of information.

Comparisons of Methodological Techniques

Due to the recent availability of a stress protein 70 antibody (hsp72/73 Ab), I was able to compare sensitivities of the radiolabel and immunological methods for assessing the SPR in fish. The incorporation of radiolabeled amino acids into proteins allowed me to examine the translation patterns as related to toxicant type and concentration. In general, to adequately induce the stress response for densitometric quantitation, acutely toxic concentrations were required. However, via quantitative immunoblots using the hsp $72 / 73$ antibody, significant accumulations of stress protein 70 at toxicant concentrations near or below the LC1 were determined consistently. Thus, the immunological methodology was 
several-fold more sensitive. However, investigations using this technique were limited to just the one stress protein due to the limited availability of other stress protein antibodies. Therefore, future investigations with fish should utilize as many stress protein antibodies as possible so as to take advantage of the suite approach to detect possible causes of biologic perturbations.

\section{Potential Pitfalls}

The use of stress proteins in environmental or ecological investigations is in its infancy. Therefore, it is necessary to express potential pitfalls in conducting such research, including data interpretation. The following paragraphs are not ordered by importance, hence subjects within this section have not been prioritized. On the contrary, each potential pitfall examined should be interpreted equal to that of the others described.

Although it is convenient to expose cells or tissues to stressors and call all expressed proteins "stress proteins", there is a real danger here. Idealized stress proteins conform to heat shock protein definitions that is, either by increased expression via heat shock, amino acid sequences, or immunological criteria. Since many "stress proteins" have not been purified and sequenced, or have had antibodies made against them, references to this terminology name should be made cautiously. However, responses that do not correspond to classical heat shock or arsenite responses should not be discounted as being stress protein responses. 
Most stress protein studies have been confined to cell cultures with in vitro exposures. Thus, "classical" responses are a result of experiments using this approach. However, my series of studies on the stress protein response in tissues of the fathead minnow have not all conformed to the traditional literature. In particular, the dramatic disparities of translation patterns between gill, striated muscle and brain in diazinon exposed fish serves as an excellent example. Presently, little is known about the interactions between organism stress physiology and the SPR. Exposure of fish to toxicants such as hypoxia, metals, pesticides, and ammonia have all been shown to elicit releases of stress hormones such as cortisol (Donaldson, 1981; Mazeud and Mazeud, 1981). Therefore, the SPR may be regulated at several levels in vivo. A positive note is that the elucidation of the interactions between the stress response at the organism level and at the cellular level may provide insight into physiologic controls of cellular function and organism homeostasis (Blake et al., 1990).

Another concern is data interpretation. Data presented from sp70 immunoblots illustrate a threshold effect, an on/off effect. These types of data are not conducive for regression analysis. Thus, regressions may indicate significance yet relatively low coefficients of determination. Discussions of regressions from these types of data should not reflect a graded-response tone as is popular in the toxicological literature.

Lastly, since data presented here clearly show that increased incorporation of radiolabel into stress proteins is sensitive to elevated temperatures, appropriate 
precautions should be made to limit this effect on chemical-induced SPR investigations.

Future Needs and Scope

In view of the results presented, several future research initiatives are warranted. Continued laboratory assessments of the SPR focusing on translation patterns in response to a wide array of chemicals is needed. With such research endevours, it may be possible to use protein patterns to indicate chemical class and/or mode-of-action. Included, should be investigations utilizing antibodies to other stress proteins, such as 20,60 , and 90 .

Field validation studies where acute to chronic or sub-chronic gradients exist should be conducted. Comparisons of the SPR to extensive water and sediment chemistry data, as well as biotic indices, are necessary to fully understand the potential efficacy and limitations of this biochemical approach to assess in situ stress.

Relationships of tissue contaminant concentrations and SPR elicitation and recovery are also necessary. Lastly, research on the SPR in aquatic species other than fish is also necessary. Due to the highly conserved nature of the SPR, techniques explored during this research project should be applicable to other life forms. Interpretation of cross-species stress responses would give valuable information on the fate and effects of environmental contaminants and could be incorporated into ecological risk assessments. 


\section{REFERENCES}

AL-CHALABI, K.A.K. AND AL-KHAYAT, B.H.A. 1989. The Effect of Lindane on Nucleic Acids, Protein and Carbohydrate Content in Tetrahymena pyriformis. Environ. Poll. 57:281-287.

AMARAL, M.D., GALEGO, L., AND RODRIGUES-POUSADO, C. 1988. Stress response of Tetrahymena pyriformis to arsenite and heat shock: differences and similarities. Eur. J. Biochem. 171:464-470.

ANANTHAN, J., GOLDBERG A.L., AND VOELLMY, R. 1986. Abnormal protiens serve as eukaryotic stress signals and trigger the activation of heat shock genes. Science 232:522-524.

ANSARI, B.A., AND KUMAR, K. 1984. Malathion Toxicity: In Vivo Inhibition of Acetylcholinesterase in the Fish Brachydanio Rerio (Cyprinidae). Toxicol. Lett. 20:283-287.

ANTUNES-MADEIRA, M.C. AND MADEIRA, V.M.C. 1989. Membrane fluidity as affected by the insecticide lindane. Biochim. Biophys. Acta. 982:161-166. 
ARIYOSHI, T., SHIIBA, S., HASEGAWA, H., AND ARIZONO, K. 1990. Profile of metal-binding proteins and heme oxygenase in red carp treated with heavy metals, pesticides and surfactants. Bull. Environ. Contam. Toxicol. 44:643-649.

ARRIGO, A.P. 1987. Cellular localization of hsp23 during Drosophila development and following subsequent heat shock. Developmental Biol. $122: 39-48$

ATKINSON, B.G. and WALDEN, D.B. 1985. Changes in eukaryotic gene expression in response to environmental stress. Academic Press, Orlando, FL.

BASHA, S.M., PRASADA RAO, R., SAMBASIVA RAO, K.R.S., AND RAMANA RAO, K.V. 1984. Respiratory Potentials of the Fish (Tilapia mossambica) Under Malathion, Carbaryl and Lindane Intoxication. Bull Environ Contam Toxicol. 32:570-574.

BAULIEU, E. 1989. Contragestion and other clinical applications of RU 486 and antiprogesterone at the receptor. Science 245: 1351-1357. 
BECKMANN, R. P., MIZZEN, L. A., WELCH, W. J. 1990. Interaction of hsp 70 with newly synthesized proteins: implications for protein folding and assembly. Science $248: 850-853$.

BENSON, W.H., AND BIRGE, W.J. 1985. Heavy metal tolerance and metallothionein induction in fathead minnows: results from field and laboratory investigations. Environ. Toxicol. Chem. 4:209-217.

BLAKE, M.J., GERSHON, D., FARGNOLI, J., AND HOLBROOK, N.J. 1990. Discordant expression of heat shock protein mRNAs in tissues of heatstressed rats. J. Biol. Chem. 265:15275-15279.

BOSCH T.C.G., KRYLOW, S.M., BODE, H.R., AND STEELE, R.E. 1988. Thermotolerance and synthesis of heat shock proteins: these responses are present in Hydra attenuata but absent in Hydra oligactis. Proc. Natl. Acad. Sci. USA 85: 7927-7931.

BOUK, G.R. 1984. Physiological responses of fish: problems and progress toward use in environmental monitoring. In Contaminant effects on fisheries. Edited by V.W. Cairns, P.R. Hodson, and J.O. Nriagu, eds., John Wiley and Sons, New York. pp. 62-71. 
BOURNIAS-VARDIABASIS, N., BUZIN, C., AND FLORES, J. 1990.

Differential expression of heat shock proteins in Drosophila embryonic cells following metal ion exposure. Exp. Cell Res. 189:177-182.

BOWLER, K., AND FULLER, B. J. 1987. Temperature and animal cells. Company of Biologists Limited, Cambridge, MA.

BRADFORD, M. M. 1976. A rapid and sensitive method for the quantitation of microgram quantities of protein utilizing the principle of protein-dye binding. Anal. Biochem. 72: 248-254.

BUHLER, D.R., STOKES R.M., AND CALDWELL, R.S. 1977. Tissue accumulation and enzymatic effects of hexavalent chromium in rainbow trout (Salmo gairdneri). J. Fish. Res. Board Can. 34:9-18.

CALDERWOOD, S. K. 1987. Role of energy in cellular responses to heat. In Temperature and animal cells. Edited by K. Bowler and B.J. Fuller. Company of Biologists Limited, Cambridge, MA. pp. 213-234.

CHEN, J. D., YEW, F. H., and LI, G. C. 1988. Thermal adaptation and heat shock response of Tilapia ovary cells. J. Cell. Physiol. 134: 189-199. 
CHENG, M. Y., HARTL, F., MARTIN, J., POLLOCK, R. A., KALOUSEK, F., NEUPERT, W., HALLBERG, E. M., HALLBERG, R. L., and HORWICH, A. L. 1989. Mitochondrial heat-shock protein hsp60 is essential for assembly of proteins imported into yeast mitochondria. Nature 337: $620-62$.

CHIRICO, W. J., WATER, M. G., and BLOBEL, G. 1988. 70K heat shock related proteins stimulate protein translocation into microsomes. Nature 332: 805-809.

CLARK. B.D., AND BROWN I.R. 1986. A retinal heat shock protein is associated with elements of the cytoskeleton and binds to calmodulin. Biochem. Biophys. Res. Comm. 136:974-981.

COPPAGE, D.L. 1977. Anticholinesterase Action of Pesticidal Carbamates in the Central Nervous System of Poisoned Fishes. In Physiological Responses of Marine Biota to Pollutants. Edited by F. J. Vernberg, A. Calabreses, F.P. Thurberg, W.B. Vernberg. Academic Press, Inc., N.Y. 93102.

COPPAGE, D.L., MATTHEWS, E., COOK, G.H., AND KNIGHT, J. 1975. 
Brain Acetylcholinesterase Inhibition in Fish as a Diagnosis of

Environmental Poisoning by Malathion, O, O-Dimethyl S-(1,2-

Dicarbethoxyethyl) Phosphorodithioate. Pesticide Biochem. and Physiol. 5:536-542.

COPPAGE, D.L. 1972. Organophosphate Pesticides: Specific Level of Brain AChE Inhibition Related to Death in Sheepshead Minnows. Trans. Amer. Fish. Soc. 113. 3:534-536.

COURGEON, A., MAISONHAUTE C., AND BEST-BELPOMME, M. 1984. Heat shock proteins are induced by cadmium in Drosophila cells. Exp. Cell Res. 153:515-521.

CRAIG, E.A. 1989. Essential roles of 70kDa heat inducible proteins. BioEssays 2: $48-52$.

CRAWSHAW, L.I. 1976. Effect of rapid temperature change on mean body temperature and gill ventilation in carp. Amer. J. Physiol. 331: 837-841.

CRAWSHAW, L.I. 1979. Responses to rapid temperature change in vertebrate ectotherms. Amer. Zool. 19: 225-237. 
CUTKOMP, L.K., KOCH, R.B. AND DESAIAH, D. 1982. Inhibition of ATPases by Chlorinated Hydrocarbons. In Insecticide mode of action. Edited by Joel R. Coats. Academic Press, New York. 45-69.

DEMAEL, A., LEPOT, D., COSSARINI-DUNIER, M. AND MONOD G. 1987. Effect of gamma-Hexachlorocyclohexane (Lindane) on Carp (Cyprinus carpio). Ecotoxicol. and Environ. Safety. 13:346-351.

DESHAIES, R.J., KOCH, B.D., WERNER-WASHBURNE, M., CRAIG, E.A., and SCHEKMAN, R. 1988. A subfamily of stress proteins facilitates translocation of secretory and mitochondrial precursor polypeptides. Nature 332: 800-805.

DONALDSON, E.M. 1981. The pituitary-interrenal axis as an indicator of stress in fish. In Stress and fish. Edited by A.D. Pickering. Academic Press. 11-47.

DUBAND, J.L., LETTRE, F., ARRIGO A.P., AND TANGUAY, R.M. 1986. Expression and localization of hsp-23 in unstressed and heat-shocked Drosophila cultured cells. Can. J. Genet. Cytol. 28:1088-1092.

DUNCAN R.F. AND HERSHEY, J.W.B. 1987. Translational repression by chemical inducers of the stress response occurs by different pathways. 
Biochem. Biophys. 256:651-661.

DURHAM, W.F. 1987. Toxicology of insecticides, rodenticides, herbicides, and fungicides. In: Toxicology. Edited by: T.J. Haley and W.O. Berndt. Hemisphere Publ. Corp., Washington. pp. 364-383.

EPA METHOD 206.2. 1979. Methods for chemical analysis of water and wastes. EPA-600 4-79-020.

EPA METHOD 218.1. 1979. Methods for chemical analysis of water and wastes. EPA-600 4-79-020.

FISHMAN, B.E. AND GIANUTSOS, G. Opposite Effects of Different Hexachlorocyclohexane (Lindane) Isomers on Cerebellar Cyclic GMP: Relation of Cyclic GMP Accumulation to Seizure Activity. Life Sciences. 41:1703-1709.

GEDAMU, L., CULHAM, B., and HEIKKILA, J. J. 1983. Analysis of the temperature-dependent temporal pattern of heat-shock-protein synthesis in fish cells. Biosci. Rep. 3: 647-658. 
GOERING, P.L., MISTRY, P., AND FOWLER, B.A. 1987. Mechanisms of metal-induced cell injury. In Toxicology. Edited by T.J. Haley and W.O. Berndt. Hemisphere Publ. Corp., Washington. pp. 384-425.

GREEN. L.A.D., AND LIEM, R.K.H. 1989. B-internexin is a microtubuleassociated protein identical to the $70-\mathrm{kDa}$ heat-shock cognate protein and the clathrin uncoating ATPase. J. Biol. Chem. 264:15210-15215.

GREENBERG, S. G., and LASEK, R. J. 1985. Comparison of labeled heat shock proteins in neuronal and non-neuronal cells of Aplysia californica. J. Neurosci. 5: 1239-1245.

GRIFFIN, J. A., and SPALDING, D. M. 1988. $V_{H}$ gene expression by nontransformed pre-B cells upon differentiation in vitro. J. Immunol. 140: 3982-3987.

GUIDON, P.T., AND HIGHTOWER, L.E. 1986. Purification and initial characterization of the 71-kilodalton rat heat-shock protein and its cognate as fatty acid binding proteins. Biochemistry 25:3231-3238.

HAMILTON, S.J., AND MEHRLE, P.M. 1986. Metallothionein in fish: review of its importance in assessing stress from metal contaminants. Trans. Amer. 
Fish. Soc. 115:596-609.

HEIKKILA, J. J., SCHULTZ, G. A., IATROU, K., and GEDAMU, L. 1982.

Expression of a set of fish genes following heat or metal ion exposure. J. Biol. Chem. 257: 12000-12005.

HIGHTOWER, L. E., and GUIDON, P. T. 1989. Selective release from cultured mammalian cells of heat-shock (stress) proteins that resemble glial-axon transfer proteins. J. Cell. Physiol. 138: 257-266.

HIWASA, T. AND SAKIYAMA, S. 1986. Increase in the synthesis of a Mr 32,000 protien in BALB/c3T3 cells after treatment with tumor promoters, chemical carcinogens, metal salts, and heat shock. Cancer Res. 46:2474-2481.

HODSON, P.V., BLUNT, B.R., AND WHITTLE, D.M. 1984. Monitoring lead exposure of fish. In Contaminant effects on fisheries. Edited by V.W. Cairns, P.V. Hodson, and J.O. Nriagu. John Wiley and Sons, New York. pp. 87-98.

HOLDWAY, D.A. 1988. The toxicity of chromium to fish. In Chromium in the natural and human environments. Edited by J.O. Nriagu and E. Nieboer. John Wiley and Sons, New York. 369-397. 
JENKINS, K.D., AND SANDERS, B.M. 1986. Assessing bioligical effects of contaminants in situ. In Urban runoff quality - proceedings of an engineering foundation conference, urban water res. ASCE Henniker, New Hampshire. June 23-27. pp. 170-181.

JOY, R.M., VOGEL, S.M. AND NARAHASHI, T. 1987. Effects of lindane upon transmitter release and end-plate responsiveness in the neuromuscular junction of the frog. Neuropharmocology. 26:1223-229.

KOBAN, M., GRAHAM, G. and PROSSER, C. L. 1987. Induction of heat-shock protein synthesis in teleost hepatocytes: effects of acclimation temperature. Physiol. Zool. 60: 290-296.

KAPOOR, M., AND LEWIS, J. 1986. Alteration of the protein synthesis pattern in Neruospora crassa cells by hyperthemral and oxidative stress. Can. J. Microbiol. 33:162-168.

KEYSE, S.M., AND TYRELL, R.M. 1989. Heme oxygenase is the major 32-kDa stress protein induced in human skin fibroblasts by UVA radiation, hydrogen peroxide, and sodium arsenite. Proc. Natl. Acad. Sci. 86:99-103. 
KIM, Y., SHUMAN J., SETTE, M., AND PRZYBYLA, A. 1984. Nuclear localization and phosphorylation of three 25-kilodalton rat stress proteins. Mol. Cell. Biol. 4:468-474.

KLEMPERER, N.S., AND PICKART, C.M. 1989. Arsenite inhibits two steps in the ubiquitin-dependent proteolytic pathway. J. biol. Chem. 264:1924519252.

KOTHARY, R.K., CANDIDO, E.P.M. 1982. Induction of a novel set of polypeptides by heat shock or sodium arsenite in cultured cells of rainbow trout, Salmo gairdnerii. Can. J. Biochem. 60:347-354.

KUHNERT, P.M., KUHNERT, B.R., AND STOKES, R.M. 1986. The effect of in vivo chromium exposure on $\mathrm{Na} / \mathrm{K}$ - and $\mathrm{Mg}$-ATPase activity in several tissues of the rainbow trout (Salmo gairdneri). Bull. Environ. Contam. Toxicol. 15:383-390.

HAHN, M.E., WOODIN, B.R., AND STEGEMAN, J.J. 1989. Induction of P450E (PO4501A1) by 2,3,7,8-tetrachlorodibenzofuran (2,3,7,8-TCDF) in the marine fish scup (Stenotomus chrysops). Mar. Environ. Res. 28:61-65. 
LAEMMLI, U. K. 1970. Cleavage of structural proteins during the assembly of the head of bacteriophage T4. Nature 227: 680-685.

LANDRY, J., BERNIER, D., CHRETIEN, P., NICOLE, L. M., TANGUAY, R. M., MARCEAU, N. 1982. Synthesis and degradation of heat shock proteins during development and decay of thermotolerance. Cancer Res. 42: $2457-2461$.

LAGERSPETZ, K.Y.H. 1987. Temperature effects on different organization levels in animals. In Temperature and animal cells. Edited by K. Bowler and B.J. Fuller. Company of Biologists Limited, Cambridge, MA. pp. 429449.

LINDQUIST, S. 1986. The heat shock response. Ann. Rev. Biochem. 55: 11511191.

LINDQUIST, S., AND CRAIG, E.A. 1988. The heat shock proteins. Ann. Rev. Genet. 22: 631-677.

MATSUMURA, F. 1985. Toxicology of insecticides. Plenum Publishing Corp., New York. pp. 598. 
MATSUMURA, F., AND GHIASUDDIN, S.M. 1983. Evidence for similarities between cyclodiene type insecticides and picrotoxinin in their action mechanisms. J. Environ. Sci. Hith. B. 18:1-14.

MAYER, F.L. 1983. Clinical tests in aquatic toxicology: A paradox? Environ. Tox. Chem. 2:139-140.

MAZEAUD, M.M., AND MAZEAUD, F. 1981. Adrenergic responses to stress in fish. In Stress and fish. Edited by A.D. Pickering. Academic Press. pp. 5075.

MCKEE, M.J., AND KNOWLES, C.O. 1986. Protein, Nucleic Acid and Adenylate Levels in Daphnia magna Chronic Exposure to Chlordecone. Elsevier Appl. Sci. Publ. Ltd, England. 42:335-351.

MCMULLIN, T. W., AND HALLBERG, R. L. 1986. Effect of heat shock on ribosome structure: appearance of a new ribosome-associated protein. Mol. Cell. Biol. 6: 2527-2535.

MELANCON, M.J., YEO, S.E., AND LECH, J.J. 1987. Induction of hepatic microsomal monooxygenase activity in fish by exposure to river water. Environ. Toxicol. Chem. 6:127-135. 
MERZ, R., AND LAUDIEN, H. 1987. Two types of heat tolerance in FHMcells. Induction by heat-shock versus elevated culturing temperature. J. therm. Biol. 12: 281-288.

MILLER, S.G. 1987. Association of a sperm-specific protein with the mitochondrial F1F0-Atpase in Heliothis. Insect. Biochem. 17:417-432.

MITANI, K., FUJITA, H., SASSA, S., AND KAPPAS, A. 1990. Activation of heme oxygenase and heat shock protein 70 genes by stress in human hepatoma cells. Biochem. Biophys. Res. Comm. 166:1429-1434.

MIZZEN, J.A., AND WELCH, W.J. 1988. Characterization of the thermotolerant cell. Effects on protein synthesis actvity and the regulation of heat-shcok protien 70 expression. J. Cell biol. 106:1105-1116.

MISRA, S., ZAFARULLAH, M., PRICE-HAUGHEY, J., AND GEDAMU, L. 1989. Analysis of stress-induced gene expression in fish cell lines exposed to heavy metals and heat shock. Biochim. Biophys. Acta, 1007: 325-333.

MOSSER, D.D., HEIKKILA, J.J., AND BOLS, N.C. 1986. Temperature ranges over which rainbow trout fibroblasts survive and synthesize heat-shock 
proteins. J. Cell. Physiol. 128: 432-440.

MOSSER, D.D., VAN OOSTROM, J., AND BOLS, N.C. 1987. Induction and decay of thermotolerance in rainbow trout fibroblasts. J. Cell. Physiol. 132: $155-160$.

MUNRO, S., AND PELHAM, J. 1985. What turns on heat shock genes? Nature $317: 477-478$.

MURPHY, S.D. 1986. Toxic effects of pesticides. In Toxicology, the basic science of poisons. Edited by C.D. Klaassen, M. O. Amdur, J. Doull. Macmillan Publ. Co., New York. pp. 519-581.

NAS (NATIONAL ACADEMY OF SCIENCES). 1974. Chromium: medical and biologic effects of environmental pollutants. Nat. Res. Council. Comm. Biol. Effects Atm. Poll. pp. 155.

NEFF, J.M. 1985. Use of biochemical measurements to detect pollutant-mediated damage to fish. In Aquatic toxicology and hazard assessment: seventh symposium. Edited by R.D. Cardwell, R. Purdy, and R.C. Bahner. American Society for Testing and Materials. 155-183. 
NIEBOER, E. AND JUSYS, A.A. 1988. Biologic chemistry of chromium. In Chromium in the natural and human environments. Edited by J.O. Nriagu, and E. Nieboer. John Wiley and Sons, New York. pp. 21-80.

NIEBOER, E. AND SHAW, S.L. 1988. Mutagenic and other genotoxic effects of chromium compounds. In Chromium in the natural and human environments. Edited by J.O. Nriagu, and E. Nieboer. John Wiley and Sons, New York. pp. 399-442.

NOVER, L. 1984. Heat shock response of eukaryotic cells. Springer-Verlag, New York. pp. 82.

OGATA, N., VOGEL, S.M. AND NARAHASHI, T. 1988. Lindane but not Deltamethrin Blocks a Component of GABA-Activated Chloride Channels. FASEB J. 2:2895-2900.

OLSON, D.L. AND CHRISTENSEN, G.M. 1980. Effects of Water Pollutants and Other Chemicals on Fish Acetylcholinesterase (in vitro). Environ. Res. 21:327-335.

ONO, B.-I. 1988. Genetic approaches in the study of chromium toxicity and resistance in yeast and bacteria. In Chromium in the natural and human 
environments. Edited by J.O. Nriagu, and E. Nieboer. John Wiley and Sons, New York. pp. 351-368.

ONTECH, INC., AND TRAC LABORATORY, INC. 1987. Use attainability analysis of Crutcho Creek and North Canadian River, Oklahoma. Assoc. Centr. Okla. Gov. pp 62.

OSTERMANN, J., HORWICH, A. L., NEUPERT, W., and HARTL, F. 1989. Protein folding in mitochondria requires complex formation with hsp60 and ATP hydrolysis. Nature 341: 125-130.

PERDEW, G. H. 1988. Association of the A $h$ receptor with the $90-\mathrm{kDa}$ heat shock protein. J. Biol. Chem. 263: 13802-13805.

PICKERING, A.D. 1981. Introduction: the concept of biological stress. In Stress and fish. Edited by A.D. Pickering, A.D. Academic Press, New York. pp. 19.

RAO PRASADA, K.S., AND ROA RAMANA, K.V. 1979. Effect of Sublethal Concerntration of Methyl Parathion of Selected Oxidative Enzymes and Organic Constituents in the Tissues of the Freshwater Fish, Tilapia Mossambica (Peters). Current Science. 8(12):526-528. 
REGAZZI, R., EPPENBERGER, U., AND FABBRO, D. 1988. The 27,000 daltons stress protiens are phosphorylated by protein kinase $\mathrm{C}$ during the tumor promoter-mediated growth inhibition of human mammary carcinoma cells. Biochem. Biophys. Res. Comm. 152:62-68.

RIABOWOL, K.T., MIZZEN, L.A., AND WELCH, W.J. 1988. Autoantibodies to the constitutive $73 \mathrm{kD}$ member of the hsp 70 family of heat shock protiens in systemic lupus erythematosus. J. Exp. Med. 168:1475-1480.

ROBERTS, J. L. 1973. Effects of thermal stress on gill ventilation and heart rate in fishes. In Responses of fish to environmental changes. Edited by W. Chavin. Charles C. Thomas, Publ., Springfield, MA. pp. 64-85.

ROSE, D. W., WELCH, W. J., KRAMER, G., and HARDESTY, B. 1989. Possible involvement of the $90-\mathrm{kDa}$ heat shock protein in the regulation of protein synthesis. J. Biol. Chem. 264: 6239-6244.

ROTHMAN, J.E. 1989. Polypeptide chain binding proteins: catalysts of protein folding and related processes in cells. Cell. 59:591-601.

RUDER, G.K., OVSENEK, N., HEIKKILA, J.J., and DOWNER, R.G.H. 1989. Examination of heat shock gene expression in nerve cord isolated from 
heat-stressed American cockroach, Periplaneta americana. Biochem. Cell. Biol. 67: 168-172.

RUTLEDGE, P. S., EASTON, D. P., and SPOTILA, J. R. 1987. Heat shock proteins from the lungless salamanders Eurycea bislineata and Desmognathus ochrophaeus. Comp. Biochem. Physiol. B, 88: 13-18.

\footnotetext{
SANDERS, B.M., MARTIN, L.S., NELSON, W.G., PHELPS, D.K., AND WELCH, W. 1990. Relationships between Accumulation of a $60 \mathrm{kDa}$ stress protien and scope-for-growth in Mytilus edulis exposed to a range of copper concentrations. Marine Environ. Res. In press.
}

SANDERS, B.M. 1990. Stress proteins: potential as multitiered biomarkers. In Biological markers of environmental contamination. Edited by J. McCarthy and L. Shugart. CRC Publishers, Boca Raton, Florida. 135-161.

SCHLESINGER, M.J. 1990. Heat shock proteins. J. Biol. Chem. 265:12111-12114.

SCHMIDT, J., LAUDIEN, H., AND BOWLER, K. 1984. Acute adjustments to high temperature in FHM-cells from Pimephales promelas (Pisces, Cyprinidae). Comp. Biochem. Physiol. A, 78: 823-828. 
SHANKLAND, D.L. 1982. Neurotoxic Action of Chlorinated Hydrocarbon Insecticides. Neurobehavioral Toxicology and Teratology. 4:805-811.

SHELTON, K.R., TODD, J.M., AND EGLE, P.M. 1986. The induction of stressrelated proteins by lead. J. Biol. Chem. 261:1935-1940.

SHIBAHARA, S., MULLER, R.M., AND TAGUCHI, T. 1987 Transcirptional control of rat heme oxygenase by heat shock. J. Biol. Chem. 262:1288912892.

SHIRLEY, M.A. AND MCKENNEY, JR. C.L. Influence of Lindane on Survival and Osmoregulatory/Metabolic Responses of the Larvae and Adults of the Estuarine Crab, Eurypanopeus depressus. In Pollution Physiology of Estuarine Organisms. Edited by W.B. Vernberg, A. Calabrese, F.P. Thurberg, F.J. Vernberg. pp. 275-297.

SIMPSON, S.R., BASTIAN, M.V., BLACK, J.J., HUTCHESON, M.R., AND JARMON, R.L. 1987. Use attainability analysis of Crutcho Creek, Oklahoma. Okla. Wat. Res. Bd. pp. 48.

SMITH, J.R. 1984. Fish Neurotoxicology. In Aquatic Toxicology. Edited by L.J. Weber. 2:107-151. 
SPEHAR, R.L., AND FIANDT, J.T. 1986. Acute and chronic effects of water quality criteria-based metal mixtures on three aquatic species. Environ. Toxicol. Chem. 5:917-931.

STEGEMAN, J.J., TENG, F., AND SNOWBERGER, E.A. 1987. Induced cytochrome P-450 in winter flounder (Pseudopleuronectes americanus) from coastal Massachusetts evaluated by catalytic assay and monoclonal antibody probes. Can. J. Fish. Aquat. Sci. 44:1270-1277.

STOCKER, R., GLAZER, A.N., AND AMES, B.N. 1987a. Antioxidant activity of albumin-bound bilirubin. Proc. Natl. Acad. Sci. 84:5918-5922.

STOCKER, R., YAMAMOTO, Y., MCDONAGH, A.M., GLAZER, A.N., AND AMES, B.N. 1987b. Bilirubin is an antioxidant of possible physiological importance. Sci. 235:1043-1046.

THIRUGNANAM, M., AND FORGASH, A.J. 1975. Environmental Impact of Mosquito Pesticides: Influence of Temefos on the Brain Acetylcholinesterase of Killifish. Environ. Physiol. Biochem. 5:451-459.

TSUKUDA, H. 1961. Temperature acclimatization on different organization levels of fishes. J. Biol. Osaka City Univ. 12: 15-45. 
TYTELL, M., AND BARBE, M. F. 1987. Synthesis and axonal transport of heat shock proteins. Neurol. Neurobiol. (Axonal Transport) 5: 473-492.

USHAKOV, B. 1964. Thermostability of cells and proteins of poikilotherms and its significance in speciation. Physiol. Rev. 44: 518-560.

VAN DER PUTTE, I., LUBBERS, J., AND KOLAR, Z. 1981. Effect of pH on uptake, tissue distribution and retention of hexavalent chromium in rainbow trout (Salmo gairdneri). Aquat. Toxicol. 1:3-18.

VAN DER PUTTE, I., AND PART, P. 1982. Oxygen and chromium transfer in perfused gills of rainbow trout (Salmo gairdneri) exposed to hexavalent chromium at two different $\mathrm{pH}$ levels. Aquat. Toxicol. 2:31-45.

VIJAYALAKSHMI, S. 1980. In vivo effects of Sumithion on tissue respiration and enzyme activity in the fish, Etroplus maculatus. Experimentia 36:12801281.

WATENPAUGH, D.E., AND BEITINGER, T. L. 1985. Se exposure and temperature tolerance of fathead minnows Pimephales promelas. J. Therm. Biol. 10: 83-86. 
WEBB, J.L. 1966. Enzyme and metabolic inhibitors, vol. III. Academic Press, New York. 595-733.

WEDEMEYER, B.A., MCLEAY, D.J., AND GOODYEAR, C.P. 1984. Assessing the tolerance of fish and fish populations to environmental stress: the problems and methods of monitoring. In Contaminant effects on fisheries. Edited by V.W. Cairns, P.V. Hodson, and J.O. Nriagu. John Wiley and Sons, New York. pp. 164-195.

WELCH, W.J. 1990. Mammalian stress response: cell physiology and biochemistry of stress protiens. In The role of the stress response in biology and disease. Edited by R. Moromoto and A. Tissieres. Cold Spring Harbor Laboratory, Cold Spring Harbor, New York. pp. 223-278.

WHATLEY, S.A., LEUNG, T., HALL, C., AND LINN, L. 1986. The brain 68kilodalton microtubule protein is a cognate form of the 70-kilodalton mammalian heat-shock protein and is present as a specific isoform in synaptosomal membranes. J. Neurochem. 47:1576-1583.

WHITE, R.L. 1976. Effects of high temperature and low calcium on neuromuscular transmission in frog. J. Therm. Biol. 1: 227- 232. 
WHITE, R. L. 1983. Effects of acute temperature change and acclimation temperature on neuromuscular function and lethality in crayfish. Physiol. Zool. 56: 174-194.

WILLIAMS, A.K. AND C.R. SOVA. 1966. Acetylchonlinesterase levels in brains of fishes from polluted waters. Bull. Environ. Contam. Toxicol. 1:198-204.

WOOLLEY, D.E. AND ZIMMER L. 1986. Effects and proposed mechanisms of action of lindane in mammals: unsolved problems. In Membrane receptors and enzymes as targets of insecticidal action. Edited by J.M. Clark, J.M. and F. Matsumura. Plenum Press, New York. pp. 1-31.

YASSI, A., AND NIEBOER, E. 1988. Carcinogenicity of chromium compounds. In Chromium in the natural and human environments. Edited by J.O. Nriagu, and E. Nieboer. John Wiley and Sons, New York. pp. 443-498.

ZAR, J. H. 1984. Biostatistical Analysis. Prentice-Hall Inc., Englewood Cliffs, NJ. pp. 718. 